\title{
Synthesis, Structure and Reactivity of
}

\section{Manganese Complexes Supported by}

\section{Carbon or Nitrogen Donor Ligands}

\author{
Dissertation \\ zur Erlangung des Doktorgrades \\ der Mathematisch-Naturwissenschaftlichen Fakultäten \\ der Georg-August-Universität zu Göttingen \\ vorgelegt von \\ Diplom-Chemiker \\ Jianfang Chai \\ aus Anyang, Henan \\ (CHINA)
}

Göttingen 2004 
D7

Referent:

Korreferent:

Tag der mündlichen Prüfung:
Prof. Dr. Dr. h. c. mult. H. W. Roesky

Prof. Dr. F. Meyer

03. 11.2004 
Dedicated to my parents and my wife for their love and affection 


\section{Acknowledgment}

The work described in this doctoral dissertation has been carried out under the guidance and supervision of Professor Dr. Dr. h. c. mult. H. W. Roesky at the Institut für Anorganische Chemie der Georg-August-Universität in Göttingen between November 2001 and August 2004.

I am sincerely grateful to

\section{Professor Dr. Dr. h. c. mult. H. W. Roesky}

for his constant guidance, motivation, suggestions and discussion throughout this work. I also thank him for the personal kindness and care during my stay in Göttingen.

I thank Mr. H.-G. Schmidt, Dr. M. Noltemeyer, Dr. I. Usón, Dr. Q. Ma, Mr. V. Jancik, Mr. D. Vidovic and Prof. J. Magull for their help in the X-ray crystal structure determinations and their friendship. I thank Mr. W. Zolke, Mr. R. Schöne and Dr. G. Elter (NMR spectra), Dr. X. Ren and Mr. J. Sass (magnetic susceptibility), Dr. D. Böhler, Mr. T. Schuchardt and Mrs. A. Rehbein (mass spectra), Mrs. A. C. Stückl (EPR spectra), Mr. M. Hesse, H.-J. Feine (IR spectra), Mr. J. Schimkowiak, Mr. M. Schlote and the staff of the Analytical Laboratories for their full support during my research work.

I would like to express my thanks to Mr. H. Zhu and Dr. C. He for collaborative work and Mr. H. Fan for theoretical calculations. I thank Dr. H. Hao, Dr. G. Bai, Dr. Y. Ding, Mrs. Y. Peng for their help at the beginning of the work. I also thank Mr. T. Blunck, Mr. S. Singh, Mr. U. N. Nehete, Mr. Z. Yang, Dr. M. Gorol, Dr. J. Janssen, Dr. H. Hohmeister, Dr. P. Lobinger, Dr. J. Rong, Dr. G. Nikiforov, Dr. A. Stasch, Mr. S. K. Srisailam, Dr. K. Most and many others for providing a friendly work atmosphere. The help rendered by Dr. M. Witt during writing this thesis is gratefully acknowledged.

I thank my former graduate advisors Prof. J. Wang and Prof. L. Tang in Nankai University (Tianjin, P. R. China), from whom I learnt my early lessons of research.

The full support and encouragement from my wife Jing Zhang, my parents and other relatives made this work possible. 


\section{Abbreviations}

\begin{tabular}{|c|c|}
\hline Ar & aryl \\
\hline av & average \\
\hline br & broad \\
\hline$n \mathrm{Bu}$ & $n$-butyl \\
\hline${ }^{\circ} \mathrm{C}$ & degree Celsius \\
\hline $\mathrm{Cp}$ & cyclopentadienyl \\
\hline $\mathrm{d}$ & day(s), doublet \\
\hline dec. & decomposition \\
\hline DME & 1,2-dimethoxyethane \\
\hline$\delta$ & chemical shift (ppm) \\
\hline$\Delta$ & difference \\
\hline EI & electron impact ionization \\
\hline Et & ethyl \\
\hline equiv (s) & equivalent(s) \\
\hline $\mathrm{g}$ & $\operatorname{gram}(\mathrm{s})$ \\
\hline $\mathrm{h}$ & hour(s) \\
\hline $\mathrm{Hz}$ & Hertz \\
\hline IR & infrared \\
\hline$J$ & coupling constant \\
\hline $\mathrm{K}$ & Kelvin \\
\hline $\mathrm{L}$ & $\mathrm{HC}(\mathrm{CMeNAr})_{2}$ \\
\hline $\mathrm{L}^{\prime}$ & monovalent ligand \\
\hline$\lambda$ & wavelength \\
\hline M & metal \\
\hline $\mathrm{M}^{+}$ & molecular ion \\
\hline $\mathrm{m}$ & multiplet \\
\hline $\mathrm{Me}$ & methyl \\
\hline $\mathrm{mg}$ & milligram $(\mathrm{s})$ \\
\hline $\min$ & minute(s) \\
\hline $\mathrm{mL}$ & milliliter(s) \\
\hline mmol & millimol(ar) \\
\hline
\end{tabular}


$m / z$

MS

$\mu$

$\tilde{v}$

NMR

$\mathrm{Ph}$

ppm

$i \operatorname{Pr}$

q

r.t.

$\mathrm{S}$

$\mathrm{t}$

tert

THF

TMEDA

TMS

Z mass/charge

mass spectrometry

bridging

wave number

nuclear magnetic resonance

Phenyl

parts per million

iso-propyl

quartet

room temperature

singlet

triplet

tertiary

tetrahydrofuran

tetramethylethylendiamin

tetramethylsilane

number of molecules in the unit cell 


\section{TABLE OF CONTENTS}

1. Introduction 1

1.1. Manganese N-Heterocyclic Carbene Complexes 1

1.2. Low-aggregated Organomanganese(II) Complexes of Type L'MnR

$\left(L^{\prime}=\right.$ monovalent ligand $)$ 2

1.3. Complexes with Low-valent and Low-coordinated Manganese ................................. 3

1.4. Dinuclear Manganese Complexes ........................................................................ 3

1.5. Aims and Objectives of the Present Work ...................................................................... 5

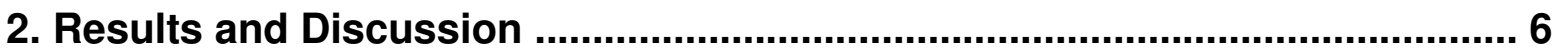

2.1. Monomeric Manganese(II) N-Heterocyclic Carbene Complexes 2 - 4 ..................... 6

2.1.1. Synthesis and Spectroscopic Characterization of Complexes

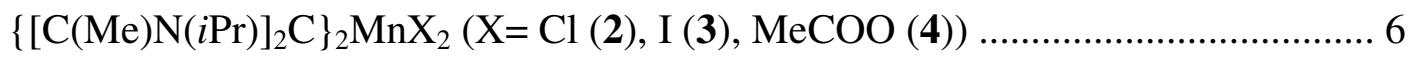

2.1.2. X-ray Solid-state Structural Analyses of Complexes 2 - 4 ................................ 7

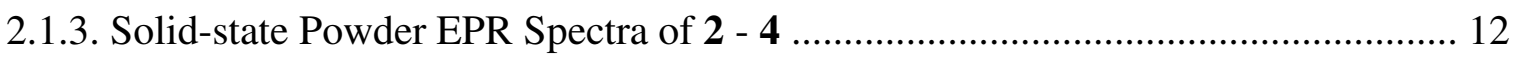

2.2. Synthesis, Structure and Reactivity of Manganese Chlorides 7 - 10 Containing

a Bulky $\beta$-Diketiminate Ligand .................................................................................................... 12

2.2.1. Synthesis and Spectroscopic Characterization of Complexes $\mathbf{7}-\mathbf{1 0}$.................... 13

2.2.2. X-ray Solid-state Structural Analyses of Complexes 7 - 10 ............................... 15

2.2.3. Reactivity of Compound $\mathbf{8}$ and its Organmanganese Derivatives $\mathbf{1 1}$ - 13

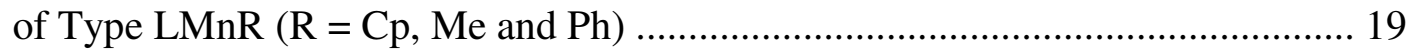

2.2.4. Reactivity of Compound 9 and Formation of Compounds $\mathrm{LMnC}_{3} \mathrm{H}_{5}$ (THF) (14)

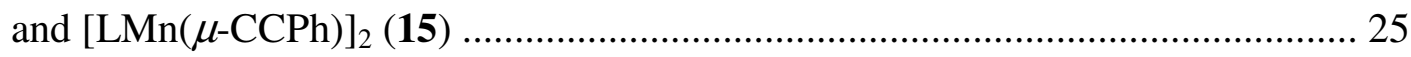

2.3. Synthesis and Structure of the Dinuclear Manganese Acetate 16 .......................... 29

2.3.1. Synthesis and Spectroscopic Characterization of $[\mathrm{LMn}(\mu-\mathrm{MeCOO})]_{2}(\mathbf{1 6}) \ldots \ldots \ldots . . .29$ 
2.3.2. X-ray Solid-state Structural Analysis of Complex 16 29

2.4. Synthesis, Structure and Reactivity of Manganese Iodides 17 - 19 Containing the Bulky $\beta$-Diketiminate Ligand

2.4.1. Synthesis and Spectroscopic Characterization of Complexes 17 - 19 31

2.4.2. X-ray Solid-state Structural Analyses of Complexes 17 and $\mathbf{1 8}$

2.4.3. Reactivity of Compound $\mathbf{1 9}$ and the Derivative

LMnNHAr $\left\{\mathrm{C}[\mathrm{N}(i \operatorname{Pr}) \mathrm{C}(\mathrm{Me})]_{2}\right\}(\mathbf{2 0})$

2.5. Synthesis, Characterization and Reactivity of the First Compound with

Three-coordinate Manganese(I) 21 ...................................................................... 37

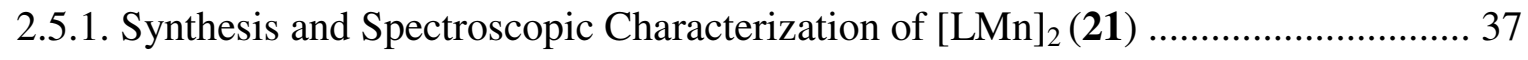

2.5.2. X-ray Solid-state Structural Analysis of Compound 21 ..................................... 37

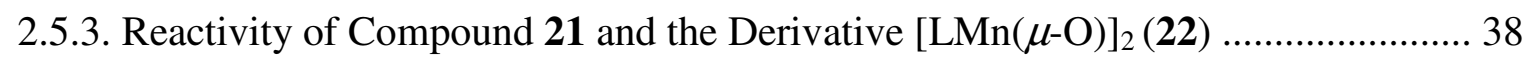

2.6. Synthesis and Structure of the Dinuclear Manganese Compound

Containing a Bulky Diamide Ligand 40

2.6.1. Synthesis and Spectroscopic Characterization of $\left[\mathrm{ArN}\left(\mathrm{CH}_{2}\right)_{3} \mathrm{NAr}\right]\left[\mathrm{Li}\left(\mathrm{OEt}_{2}\right)\right]_{2}$

(23) and $\mathrm{Mn}_{2}\left[\mathrm{ArN}\left(\mathrm{CH}_{2}\right)_{3} \mathrm{NAr}\right]_{2}$ (24)

2.6.2. X-ray Solid-state Structural Analyses of Compounds 23 and 24 41

2.6.3. Magnetic Susceptibility Measurement of Compound 24 44

3. Summary and Outlook 46

3.1. Summary 46

3.2. Outlook 52

4. Experimental Section 53

4.1. General procedures ..................................................................................................................... 53

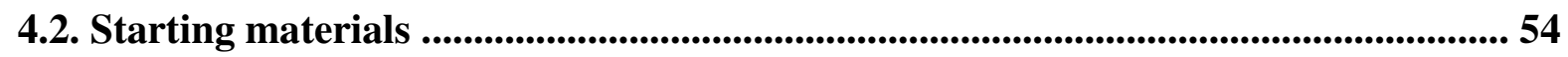

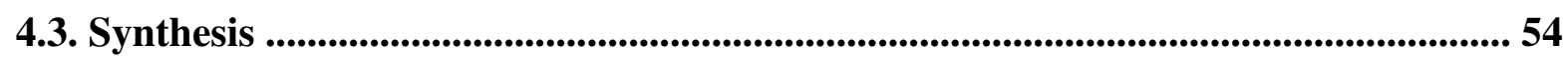




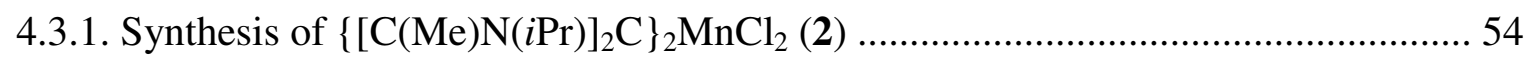

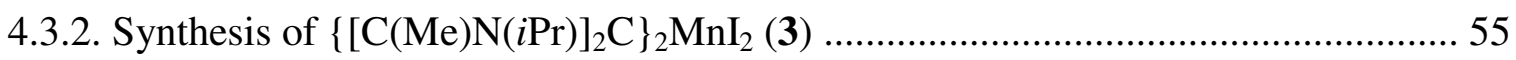

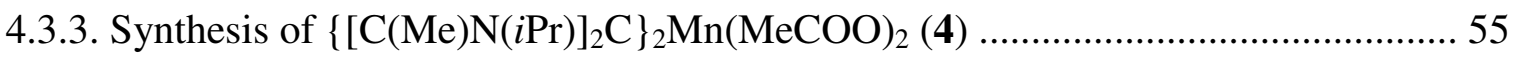

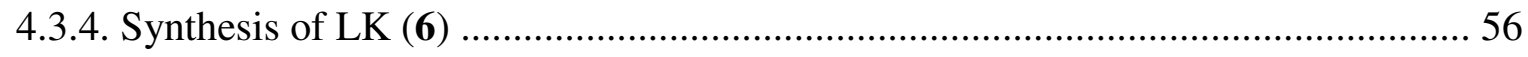

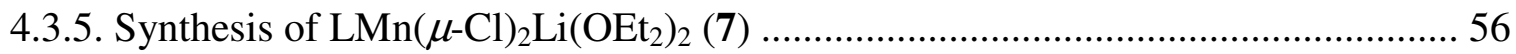

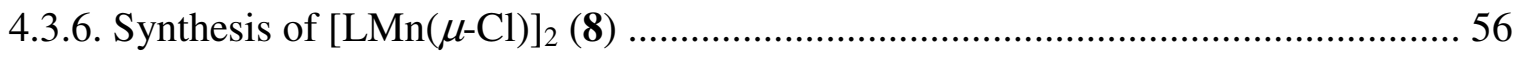

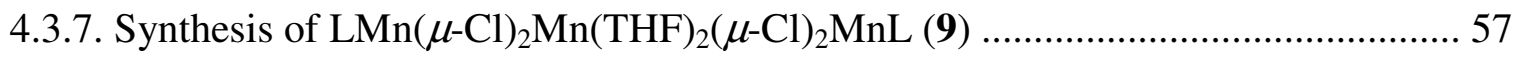

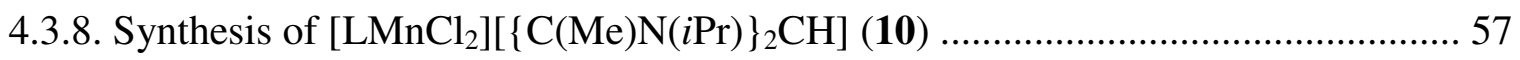

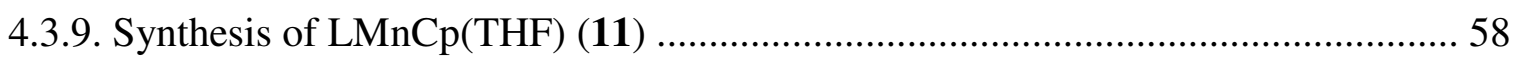

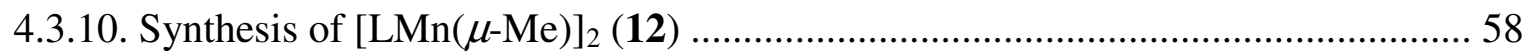

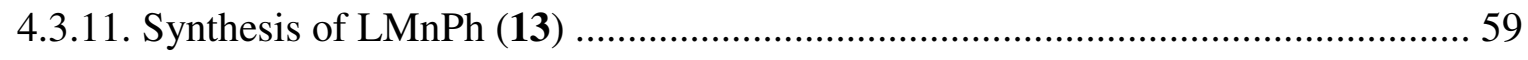

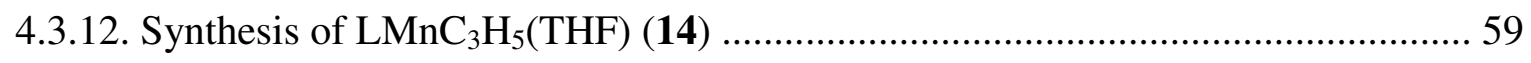

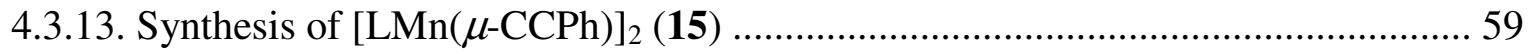

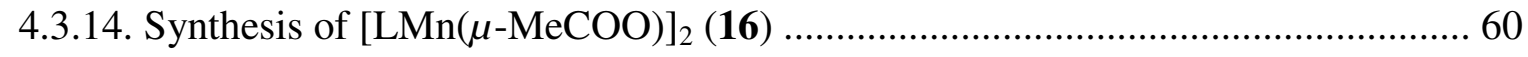

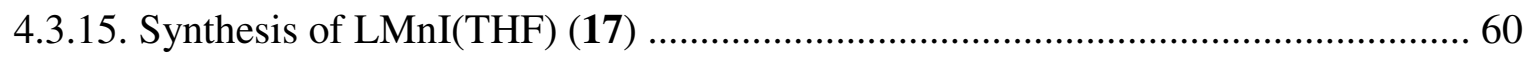

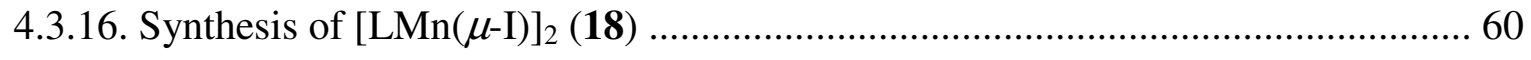

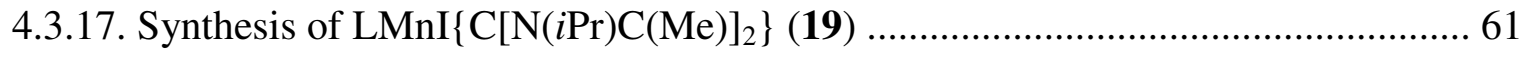

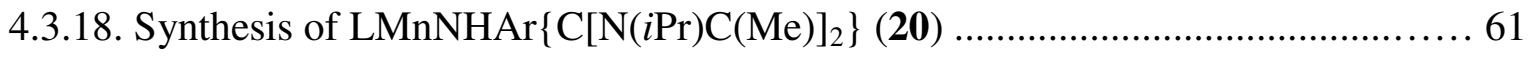

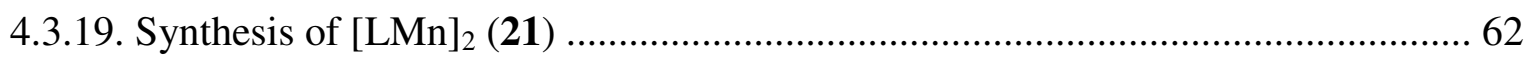

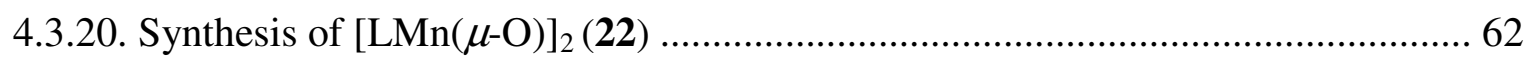

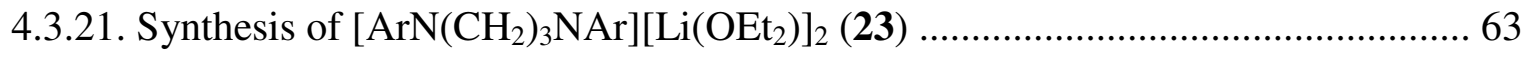

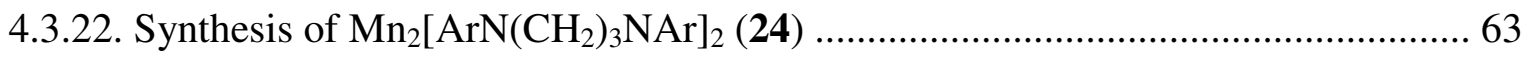

5. Handling and Disposal of Solvents and Residual Wastes ......................... 64

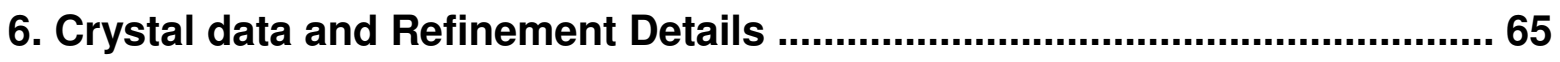

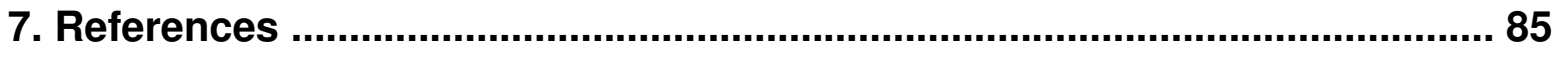




\section{Introduction}

There is widespread interest in manganese complexes due to their synthetic methodology, theoretical implications and vantage of applications in organic synthesis and catalysis. ${ }^{1}$ In addition, manganese complexes have attracted special attention regarding their important role in the material science and bioinorganic chemistry. ${ }^{2}$ Development of new materials with novel magnetic properties and attempts to model the structures and functions of manganese metalloenzymes have driven this area as the most active and expansive field. ${ }^{2}$ The discovery of the selective epoxidation catalysts based on the $\mathrm{Mn}$ (III) salen system has also attracted much effort on the manganese coordination chemistry in the search for higher selectivities and enantiospecific catalysis. ${ }^{2,3}$ However, synthesizing such complexes is still a challenge for the chemists along with the investigation of spectroscopic and structural characteristics of these molecules and perspective elaborating new catalysts. In this connection, design and choice of the ligands are important for these purposes.

In the following part, some of the work, which is related to the content of the present thesis, will be discussed in detail.

\subsection{Manganese N-Heterocyclic Carbene Complexes}

$\mathrm{N}-\mathrm{Heterocyclic}$ carbenes have attracted great attention in ligand design and homogeneous catalysis as neutral and two electron donors ${ }^{4}$ since Arduengo et al. reported the first stable crystalline N-heterocyclic carbene in $1991 .^{5}$ The isolation of the free stable N-heterocyclic carbenes enables the easy synthesis of a variety of carbene adducts that previously were inaccessible. ${ }^{6}$ So a number of N-heterocyclic carbene complexes of main group element and transition metal have been synthesized and isolated, ${ }^{4}$ some of which have been successfully applied as catalysts in a variety of organic reactions such as iridium-catalyzed transfer hydrogenation $^{7}$ and ruthenium-catalyzed olefin metathesis, especially palladium-catalyzed C-C coupling reactions: the Heck, Suzuki and Kumada reactions. ${ }^{4,8}$ Recently, iron(II) halides bearing $\mathrm{N}$-heterocyclic carbene ligand of composition $\left\{[\mathrm{C}(\mathrm{Me}) \mathrm{N}(i \mathrm{Pr})]_{2} \mathrm{C}\right\}_{2} \mathrm{Fe} \mathrm{X}_{2}(\mathrm{X}=$ $\mathrm{Cl}, \mathrm{Br}$ ) were found to be remarkably active and efficient catalysts for atom transfer radical polymerization. ${ }^{9}$ 
Manganese carbene complexes are important due to their applications in organic synthesis and theoretical implications. ${ }^{10}$ In spite of the impressive results of N-heterocyclic carbene complexes, manganese complexes containing N-heterocyclic carbenes are rare and have not attracted much attention to date. ${ }^{4 a}$ To the best of our knowledge, only few manganese Nheterocyclic carbene complexes are known including $\mathrm{MeC}_{5} \mathrm{H}_{4}(\mathrm{CO})_{2} \mathrm{MnC}\left[\mathrm{N}(\mathrm{Me}) \mathrm{CH}_{2}\right]_{2}{ }^{11}$ $(\mathrm{CO})_{3} \mathrm{MnBr}\left\{\mathrm{C}\left[\mathrm{N}(\mathrm{Me}) \mathrm{CH}_{2}\right]_{2}\right\}_{2}{ }^{11}$ and $(\mathrm{CO})_{5} \mathrm{MnC}\left[\mathrm{N}\left(\mathrm{BH}_{3}\right) \mathrm{C}(\mathrm{Me}) \mathrm{C}(\mathrm{Me}) \mathrm{N}(\mathrm{Me})\right]^{12}$ with a formal oxidation state of +1 at the manganese. Furthermore, no X-ray structural data of manganese $\mathrm{N}$-heterocyclic carbene complexes were available. Therefore, it was of interest to synthesize and structurally characterize N-heterocyclic carbene complexes containing manganese with the most common oxidation state +2 .

\subsection{Low-aggregated Organomanganese(II) Complexes of Type L'MnR $\left(L^{\prime}=\right.$ monovalent ligand $)$}

There is widespread interest in organomanganese(II) complexes, since such complexes have extensive applications in organic synthesis. ${ }^{1 c, 1 d}$ For instance, manganese(II) alkyl and aryl complexes have proved to be excellent reagents in $\mathrm{C}-\mathrm{C}$ coupling reactions and can be compared to other organotransition metal complexes such as widely used organocopper reagents. ${ }^{13}$ Moreover, they show excellent thermal stability, high chemoselectivity and excellent functional group tolerance. ${ }^{13,14}$ In spite of the impressive results obtained thus far, major efforts are focused on carbonyl and cyclopentadienyl complexes. Organomanganese complexes having ligands without carbonyl and cyclopentadienyl groups are far less abundant although the chemistry of those species is no less interesting, ${ }^{1 \mathrm{a}}$ in which complexes of type L'MnR ( $\mathrm{L}^{\prime}=$ monovalent ligand) are even more rare. Compounds of composition $\mathrm{XMnR}(\mathrm{X}=$ halide$)$ have only been used as intermediates without isolation. ${ }^{15}$ To the best of our knowledge, only few compounds of composition $\left[\mathrm{MnR}\left(\mathrm{NPEt}_{3}\right)\right]_{4}(\mathrm{R}=\mathrm{Me}, n \mathrm{Bu}, \mathrm{PhCC}$, 4- $\mathrm{MeC}_{6} \mathrm{H}_{4} \mathrm{CC}, \mathrm{Me}_{3} \mathrm{SiCC}$ ) have been structurally characterized containing a heterocubane structure. ${ }^{16}$ Despite of the interesting perspectives of organomanganese(II) complexes, there are no structural investigations known of lower aggregated complexes (monomer or dimer). So it was of interest to prepare low-aggregated organomanganese complexes by designing suitable ligands. 


\subsection{Complexes with Low-valent and Low-coordinated Manganese}

Complexes with low-valent manganese are important due to their photochemistry as well as their significance in free-radical chemistry. ${ }^{17}$ For example, the dinuclear carbonyl compound $\mathrm{Mn}_{2}(\mathrm{CO})_{10}$ has shown rich photochemistry and can catalyze the ring opening of $\beta$-propiothiolactones. ${ }^{18}$

Transition metal complexes containing low-coordinated metal centers are quite rare. Partly this is due to the difficulty associated for such metal sites to acquire 16 or 18 valence electrons. Low-coordination numbers often yield the metal centers of unusual orbital structure,${ }^{19}$ which would also render its reactivity very interesting. ${ }^{19}$ Although manganese complexes with low-coordinated centers are known, these involve manganese in oxidation states of +2 or higher. ${ }^{20}$ To the best of our knowledge, coordination number three are rare in complexes with low-valent manganese until now. In this view, one can realize that the ligand design combined with the corresponding synthetic methodology for complexes with lowvalent and low-coordinated manganese centers is an exciting challenge. In addition, it is of interest to explore their unique reactivity.

\subsection{Dinuclear Manganese Complexes}

Dinuclear manganese complexes, especially those with carboxylate or oxygen bridges, are important since such molecules are involved in many natural processes. ${ }^{21}$ Dinuclear manganese core are often seen in biological systems, such as manganese catalase, manganese ribonucleotide, arginase and thiosulfate oxidase, which exist as the catalytic centers of these enzymes. ${ }^{22}$ Manganese catalases are the well-studied redox enzymes, which protect organisms from oxidative damage to scavenge the appreciable levels of $\mathrm{H}_{2} \mathrm{O}_{2}$ produced during $\mathrm{O}_{2}$ metabolism in cells. ${ }^{22}$ They are capable of catalyzing the disproportionation of high level $\mathrm{H}_{2} \mathrm{O}_{2}$ to $\mathrm{O}_{2}$ and $\mathrm{H}_{2} \mathrm{O}$, and each unit contains a dinuclear manganese core as the catalytic center. The dimanganese core works as a two-electron mediator between a $[\mathrm{Mn}(\mathrm{III})]_{2}$ form and a reduced $[\mathrm{Mn}(\mathrm{II})]_{2}$ form in $\mathrm{H}_{2} \mathrm{O}_{2}$ disproportionation. ${ }^{23}$ A possible mechanism of this process is shown in Scheme 1 (DH/D represent the proton donor and acceptor). ${ }^{22}$ In recent years, several kinds of dinuclear manganese model complexes have been explored and show catalase activity. ${ }^{24}$ However, only a few of these functional model systems proceed via the $[\mathrm{Mn}(\mathrm{II})]_{2} \rightleftharpoons[\mathrm{Mn}(\mathrm{III})]_{2}$ redox 
cycle similar to the enzymes. ${ }^{24}$ Therefore it is still a challenge for chemists to mimic the coordination environment and functions of the manganese centers in such enzymes.

\section{Scheme 1}

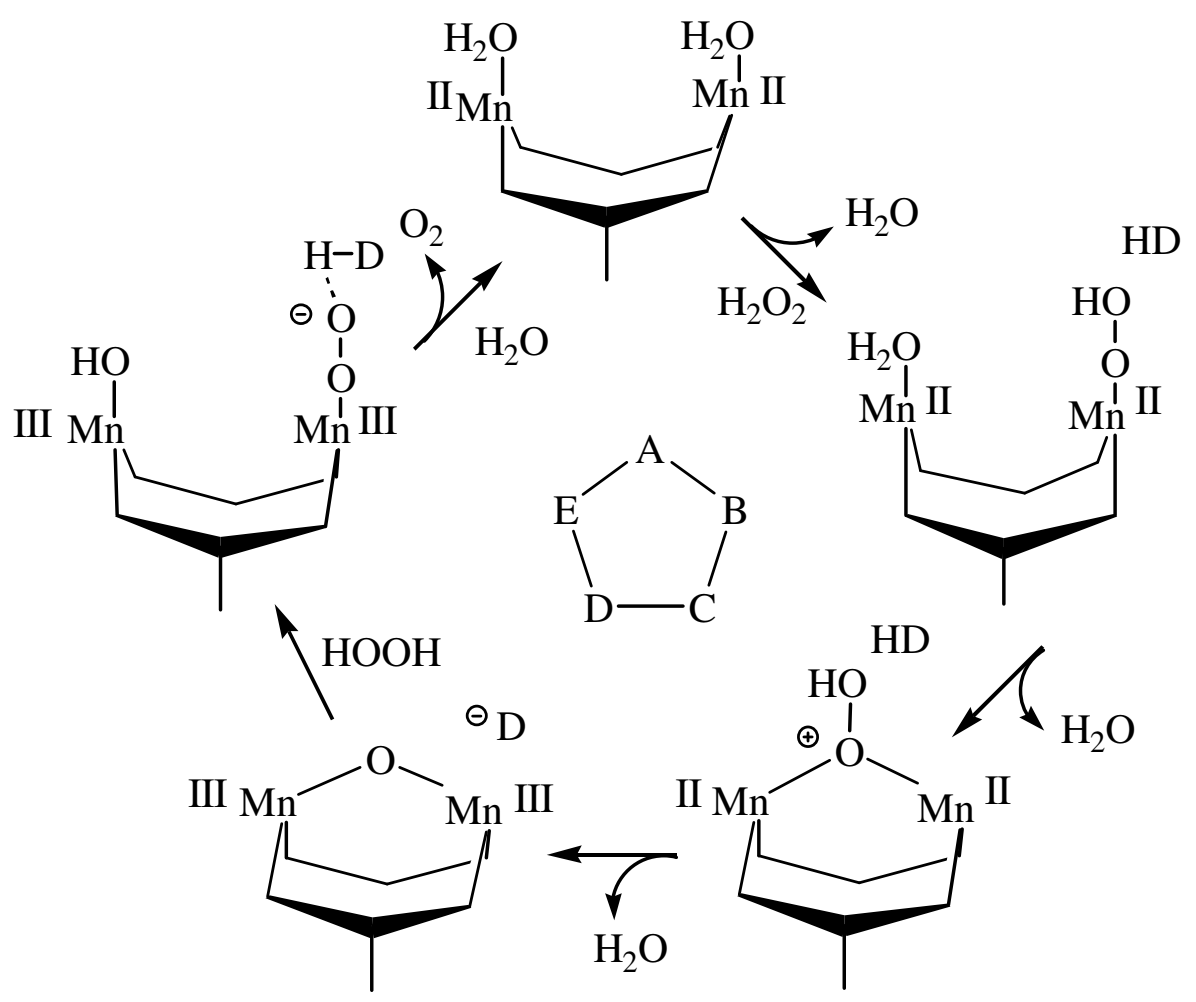




\subsection{Aims and Objectives of the Present Work}

Based on the aforementioned background materials, there is clearly a vast potential to explore the chemistry of manganese by carefully selecting or designing ligands. The aims of this thesis are the following by using the appropriate ligand systems:

- To synthesize manganese(II) N-heterocyclic carbene complexes and investigate their properties;

- To synthesize low-aggregated organomanganese(II) complexes of type L'MnR;

- To study the synthesis, property and reactivity of complexes with low-valent and lowcoordinated manganese;

- To investigate the synthesis and property of dinuclear manganese compounds. 


\section{Results and Discussion}

\subsection{Monomeric Manganese(II) N-Heterocyclic Carbene Complexes 2 - 4}

\subsubsection{Synthesis and Spectroscopic Characterization of Complexes} $\left\{[\mathrm{C}(\mathrm{Me}) \mathrm{N}(i \mathrm{Pr})]_{2} \mathrm{C}\right\}_{2} \mathrm{MnX}_{2}(\mathrm{X}=\mathrm{Cl}(2), \mathrm{I}(3), \operatorname{MeCOO}(4))$

The isolation of free stable N-heterocyclic carbenes enables the easy synthesis of a variety of carbene adducts that previously were inaccessible. ${ }^{6}$ The reaction of $\mathrm{MnCl}_{2}(\mathrm{THF})_{1.5}, \mathrm{MnI}_{2}$ and $\mathrm{Mn}(\mathrm{MeCOO})_{2}$, respectively, with 2 equiv. of the stable carbene $[\mathrm{C}(\mathrm{Me}) \mathrm{N}(i \mathrm{Pr})]_{2} \mathrm{C}(\mathbf{1})$ in THF at room temperature readily afforded the corresponding carbene adducts $\mathbf{2}-\mathbf{4}$ in good yields (Scheme 2).

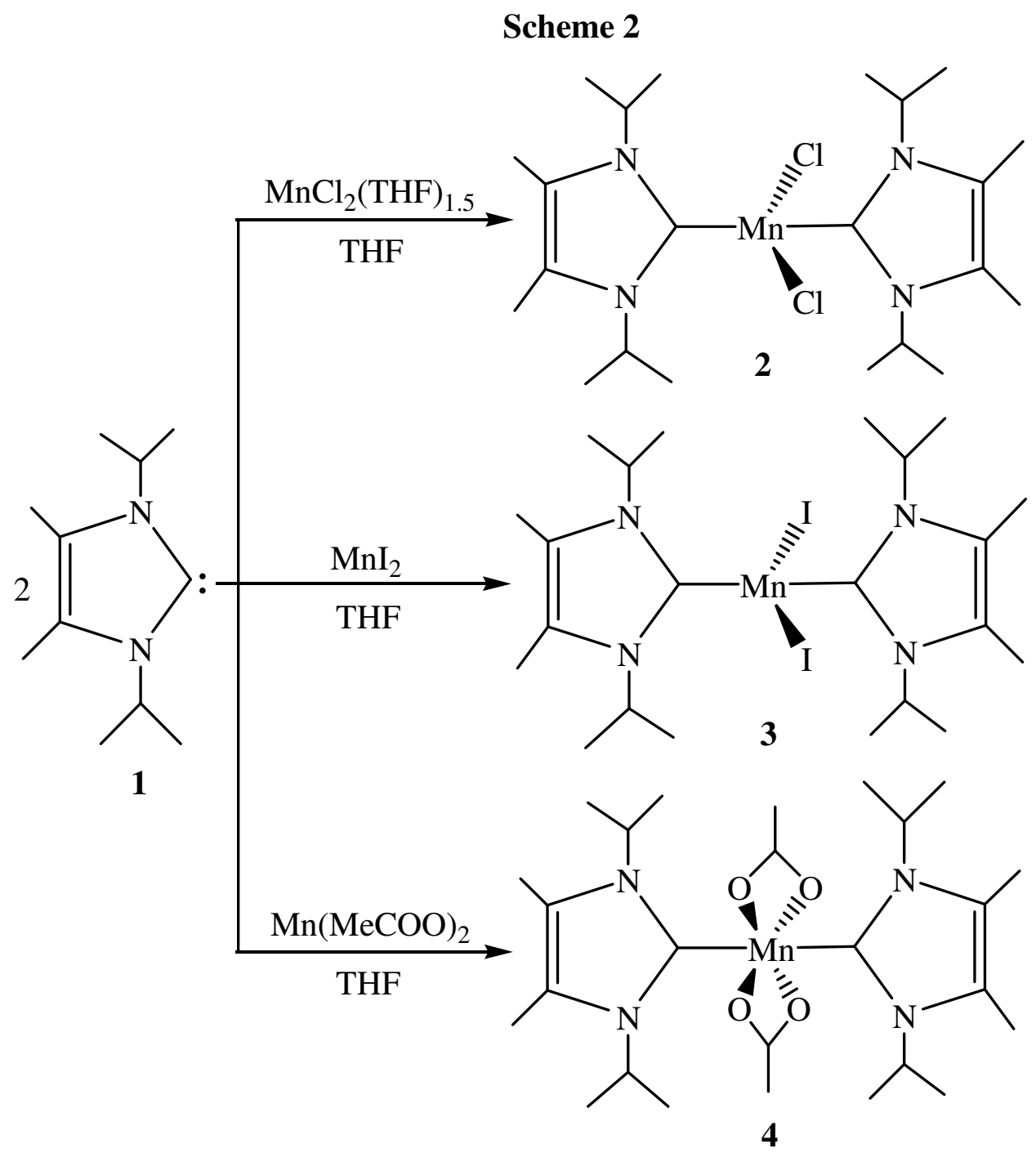


Compounds $\mathbf{2}$ and $\mathbf{4}$ are colorless solids and compound $\mathbf{3}$ is a light-orange solid. Compounds $\mathbf{2}$ and $\mathbf{3}$ are moderately air sensitive and can be exposed to air for a short period of time as solids, while compound $\mathbf{4}$ is much more sensitive. All compounds $\mathbf{2}-\mathbf{4}$ are of poor solubility in nonpolar solvents, while readily soluble in solvents such as $\mathrm{CH}_{2} \mathrm{Cl}_{2}$ and $\mathrm{MeCN}$. Compound $\mathbf{4}$ has also a good solubility in THF, but $\mathbf{2}$ and $\mathbf{3}$ are sparingly soluble in THF. Complexes $\mathbf{2}$ - $\mathbf{4}$ have been characterized by mass spectrometry, IR spectroscopy, $X$-band EPR, microanalysis and X-ray solid-state structural analyses. EI-MS spectra of these compounds are similar: the molecular ion peaks are not observed rather the free carbene fragment appears as the most intense peak at $\mathrm{m} / z 180(100 \%)$ indicating the cleavage of the $\mathrm{Mn}-\mathrm{C}$ bond in these compounds under electron-impact mass spectrometry conditions. consistent with the results reported in the literature. ${ }^{25}$ The IR spectrum of compound 4 displays two prominent vibrations for the O-C-O part of the acetate group $v_{a s}\left(1599 \mathrm{~cm}^{-1}\right)$ and $v_{s}\left(1406 \mathrm{~cm}^{-1}\right)$.

\subsubsection{X-ray Solid-state Structural Analyses of Complexes 2 - 4}

Compounds $\mathbf{2}$ and $\mathbf{3}$ are the first structurally characterized manganese halides possessing N-heterocyclic carbene ligands. Single crystals of $\mathbf{2}$ and $\mathbf{3}$ suitable for X-ray structural analyses were obtained by recrystallization in THF at $4{ }^{\circ} \mathrm{C}$, respectively. The molecular structures of $\mathbf{2}$ and $\mathbf{3}$ are shown in Figures 1 and 2, respectively; selected bond lengths and angles are listed in Table 1.

The manganese atoms in $\mathbf{2}$ and $\mathbf{3}$ are bonded to two halides and two carbene carbons and have a distorted tetrahedral geometry. A crystallographic twofold axis passes through the metal atom bisecting the angles $\mathrm{X}-\mathrm{Mn}-\mathrm{X}$ and $\mathrm{C}-\mathrm{Mn}-\mathrm{C}$. There is a slight difference between the two structures due to the different ion radius of $\mathrm{Cl}$ and I. Both the $\mathrm{X}-\mathrm{Mn}-\mathrm{X}\left(111.5^{\circ}\right)$ and C-Mn-C $\left(103.0^{\circ}\right)$ angles in $\mathbf{2}$ are slightly larger than the corresponding ones in $\mathbf{3}\left(109.0^{\circ}\right.$ and $102.4^{\circ}$, respectively). The dihedral angle between the two carbene planes is $84.5^{\circ}$ in 2 and $77.0^{\circ}$ in 3 . These differences possibly result from the stronger repulsion between iodine and carbene in $\mathbf{3}$ than that between chlorine and carbene in $\mathbf{2}$, which are also reflected by the EPR spectra.

The Mn-C bond lengths (av. 2.21 $\AA$ ) in $\mathbf{2}$ and $\mathbf{3}$ are in the expected range of Mn-C single bonds, but significantly shorter in comparison with the Mn-P bond lengths found in $\mathrm{MnI}_{2}\left(\mathrm{PEt}_{3}\right)_{2}{ }^{26}$ (av. $2.53 \AA$ ) and $\left[\mathrm{MnI}_{2}\left(\mathrm{PPhMe}_{2}\right)\right]_{\mathrm{n}}{ }^{27}$ (av. $2.67 \AA$ ). The Mn-I distances (av. $2.72 \AA$ ) in 3 are a little longer than those in $\mathrm{MnI}_{2}\left(\mathrm{PEt}_{3}\right)_{2}{ }^{26}$ (av. $2.67 \AA$ ) due to the different 
trans effect. However, the I-Mn-I (109.0 $)$ and C-Mn-C $\left(102.4^{\circ}\right)$ angles in 3 are significantly smaller than the corresponding ones $\left(120.1^{\circ}\right.$ and $115.1^{\circ}$, respectively) in $\mathrm{MnI}_{2}\left(\mathrm{PEt}_{3}\right)_{2}{ }^{26}$

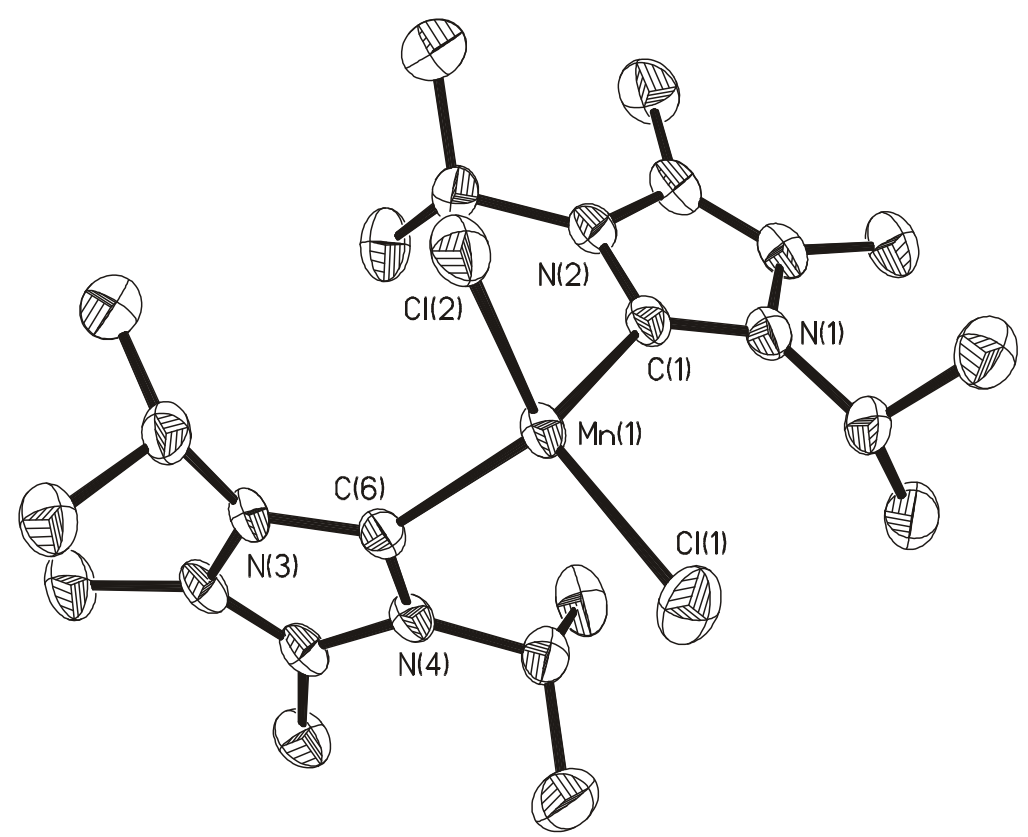

Figure 1. Molecular structure of 2 (50\% probability ellipsoids). Hydrogen atoms are omitted for clarity.

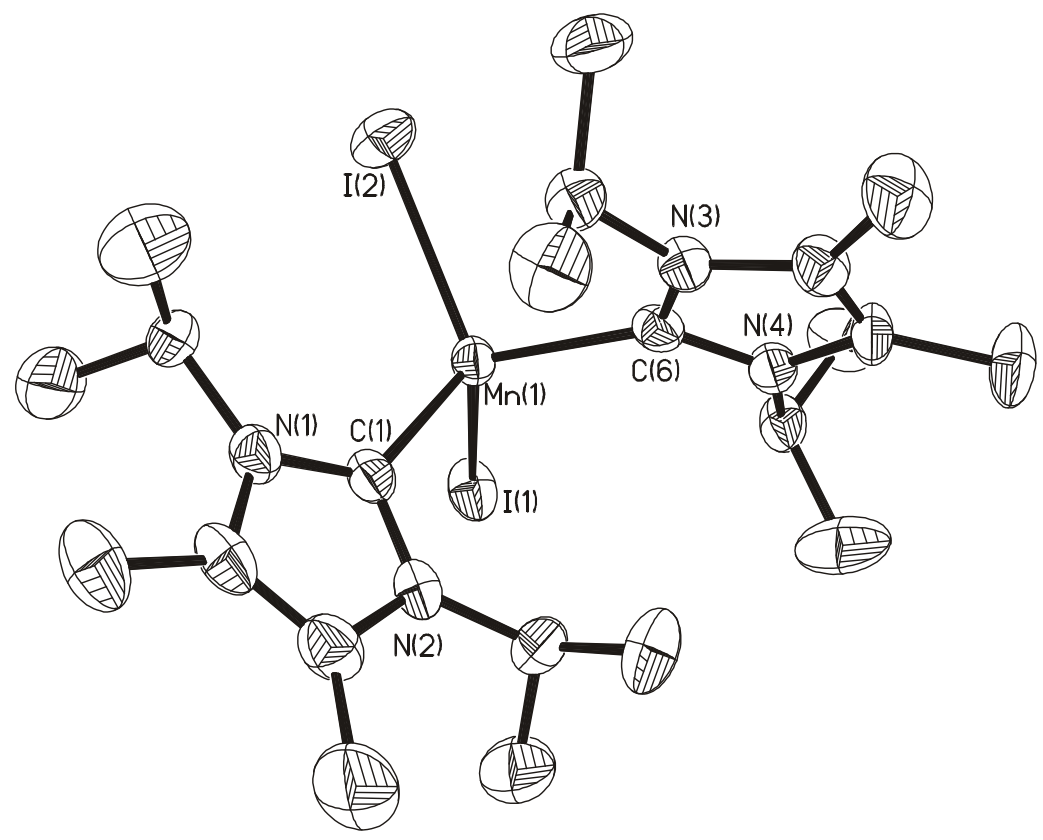

Figure 2. Molecular structure of $\mathbf{3}$ (50\% probability ellipsoids). Hydrogen atoms are omitted for clarity. 
The $\mathrm{N}(1)-\mathrm{C}(1)-\mathrm{Mn}(1)\left(131.6^{\circ}\right)$ and $\mathrm{N}(3)-\mathrm{C}(6)-\mathrm{Mn}(1)\left(132.3^{\circ}\right)$ angles in 2 deviate significantly from their corresponding counterparts $\mathrm{N}(2)-\mathrm{C}(1)-\mathrm{Mn}(1)\left(123.9^{\circ}\right)$ and $\mathrm{N}(4)$ $\mathrm{C}(6)-\mathrm{Mn}(1)\left(122.6^{\circ}\right)$, which implies that both the N-heterocyclic carbenes are in-plane bending. ${ }^{28}$ However, out-of-plane bending is only observed for one N-heterocyclic carbene ligand $(\mathrm{C}(6), \mathrm{N}(3), \mathrm{C}(7), \mathrm{C}(8)$ and $\mathrm{N}(4))$ and the $\mathrm{Mn}(1)-\mathrm{C}(6)$ bond is out of the $\mathrm{N}$ heterocyclic carbene plane by $6.4^{\circ}$. The other N-heterocyclic carbene and the central manganese atom are coplanar. In $\mathbf{3}$, both the $\mathrm{N}$-heterocyclic carbene ligands are out-of-plane bending as shown by the $\mathrm{Mn}-\mathrm{C}$ bond angles deviating from the corresponding $\mathrm{N}$ heterocyclic carbene planes by $4.7^{\circ}$ and $4.3^{\circ}$, respectively. These angles are in the normal range. $^{25}$

Table 1. Selected bond lengths $(\AA)$ and bond angles $\left({ }^{\circ}\right)$ for compounds 2 and $\mathbf{3}$

\begin{tabular}{|c|c|c|c|}
\hline \multicolumn{4}{|c|}{ Compound 2} \\
\hline $\mathrm{Mn}(1)-\mathrm{Cl}(1)$ & $2.3535(11)$ & $\mathrm{C}(6)-\mathrm{Mn}(1)-\mathrm{C} 1(1)$ & $108.92(9)$ \\
\hline $\operatorname{Mn}(1)-\mathrm{Cl}(2)$ & $2.3575(10)$ & $\mathrm{C}(1)-\mathrm{Mn}(1)-\mathrm{Cl}(2)$ & $105.78(8)$ \\
\hline $\operatorname{Mn}(1)-C(1)$ & $2.214(3)$ & $\mathrm{N}(1)-\mathrm{C}(1)-\mathrm{Mn}(1)$ & $131.6(2)$ \\
\hline $\operatorname{Mn}(1)-C(6)$ & $2.219(3)$ & $\mathrm{N}(3)-\mathrm{C}(1)-\mathrm{Mn}(1)$ & $132.3(2)$ \\
\hline $\mathrm{N}(1)-\mathrm{C}(1)$ & $1.355(4)$ & $\mathrm{C}(6)-\mathrm{Mn}(1)-\mathrm{Cl}(2)$ & $114.64(9)$ \\
\hline $\mathrm{N}(2)-\mathrm{C}(1)$ & $1.355(4)$ & $\mathrm{Cl}(1)-\mathrm{Mn}(1)-\mathrm{Cl}(2)$ & $111.47(4)$ \\
\hline$N(3)-C(6)$ & $1.355(4)$ & $\mathrm{N}(1)-\mathrm{C}(1)-\mathrm{N}(2)$ & $104.5(3)$ \\
\hline$N(4)-C(6)$ & $1.359(4)$ & $\mathrm{N}(3)-\mathrm{C}(6)-\mathrm{N}(4)$ & $104.6(3)$ \\
\hline $\mathrm{C}(1)-\mathrm{Mn}(1)-\mathrm{C}(6)$ & $103.02(12)$ & $\mathrm{N}(2)-\mathrm{C}(1)-\mathrm{Mn}(1)$ & $123.9(2)$ \\
\hline $\mathrm{C}(1)-\mathrm{Mn}(1)-\mathrm{Cl}(6)$ & $112.77(9)$ & $\mathrm{N}(4)-\mathrm{C}(1)-\mathrm{Mn}(1)$ & $122.6(2)$ \\
\hline \multicolumn{4}{|c|}{ Compound $\mathbf{3}$} \\
\hline $\mathrm{Mn}(1)-\mathrm{I}(1)$ & $2.7307(7)$ & $\mathrm{C}(1)-\mathrm{Mn}(1)-\mathrm{I}(1)$ & $106.46(10)$ \\
\hline $\operatorname{Mn}(1)-I(2)$ & $2.7114(8)$ & $\mathrm{C}(6)-\mathrm{Mn}(1)-\mathrm{I}(1)$ & $116.60(10)$ \\
\hline $\operatorname{Mn}(1)-C(1)$ & $2.210(4)$ & $\mathrm{C}(1)-\mathrm{Mn}(1)-\mathrm{I}(2)$ & $116.89(11)$ \\
\hline $\operatorname{Mn}(1)-C(6)$ & $2.204(4)$ & $\mathrm{N}(1)-\mathrm{C}(1)-\mathrm{Mn}(1)$ & $131.7(3)$ \\
\hline $\mathrm{N}(1)-\mathrm{C}(1)$ & $1.356(5)$ & $\mathrm{N}(3)-\mathrm{C}(1)-\mathrm{Mn}(1)$ & $124.5(3)$ \\
\hline $\mathrm{N}(2)-\mathrm{C}(1)$ & $1.352(6)$ & $\mathrm{C}(6)-\mathrm{Mn}(1)-\mathrm{I}(2)$ & $105.79(11)$ \\
\hline $\mathrm{N}(3)-\mathrm{C}(6)$ & $1.354(5)$ & $\mathrm{I}(1)-\mathrm{Mn}(1)-\mathrm{I}(2)$ & $109.04(2)$ \\
\hline$N(4)-C(6)$ & $1.352(5)$ & $\mathrm{N}(1)-\mathrm{C}(1)-\mathrm{N}(2)$ & $104.7(3)$ \\
\hline $\mathrm{C}(1)-\mathrm{Mn}(1)-\mathrm{C}(6)$ & $102.35(15)$ & $\mathrm{N}(3)-\mathrm{C}(6)-\mathrm{N}(4)$ & $104.1(3)$ \\
\hline
\end{tabular}


Compound 4 is the first structurally characterized monomeric manganese complex containing two symmetric chelating acetate groups. Single crystals suitable for X-ray structural analysis were grown from THF solution at $-26{ }^{\circ} \mathrm{C}$. The molecular structure is shown in Figure 3; selected bond lengths and bond angles are listed in Table 2. Complex 4 crystallizes in the monoclinic space group $C 2 / c$. The central manganese atom is surrounded by four oxygen atoms from the two chelating carboxyl groups and two carbene carbon atoms in a highly distorted octahedral geometry. The complex adopts a symmetric structure. A mirror plane passes through the manganese atom bisecting the two acetate groups and the two carbenes.

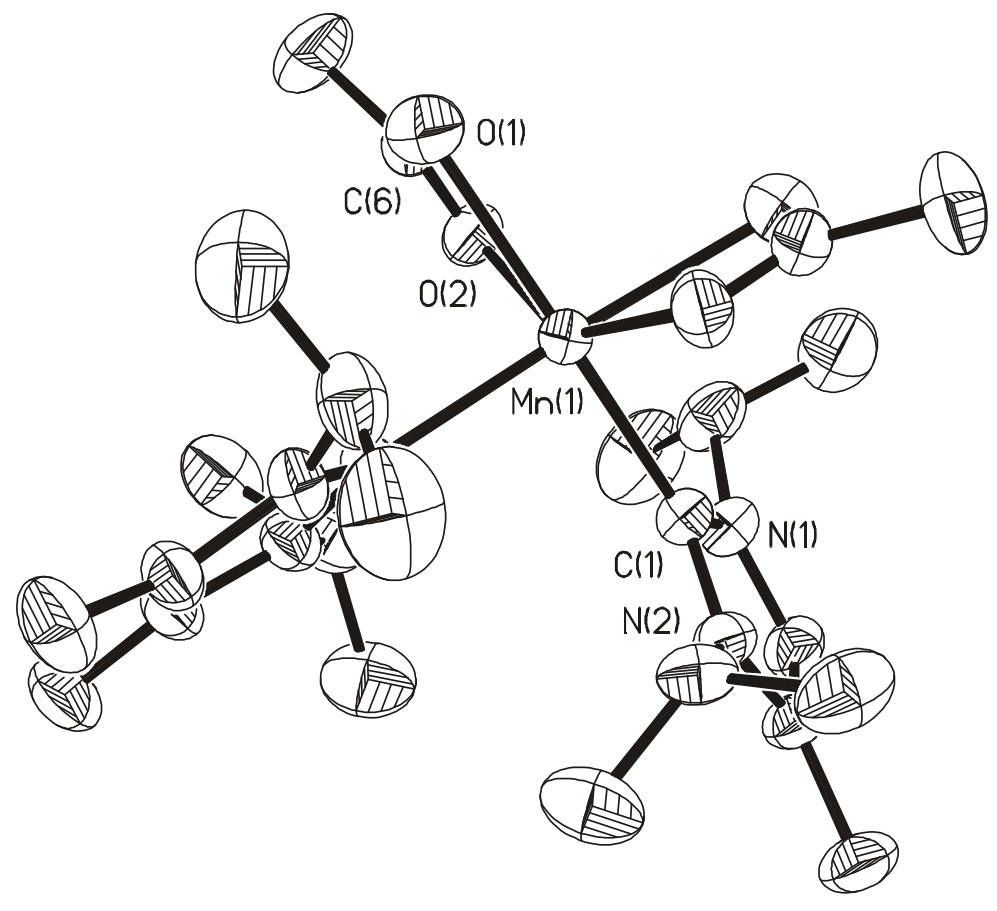

Figure 3. Molecular structure of 4 (50\% probability ellipsoids). Hydrogen atoms are omitted for clarity.

The two acetate groups are symmetrically bonded in a chelating fashion to the manganese atom resulting in the formation of two $\mathrm{MnOCO}$ four-membered rings. Both rings are planar and nearly orthogonal as shown by a dihedral angle of $85.8^{\circ}$. Manganese complexes containing chelating carboxyl groups are rare. ${ }^{29}$ The $\mathrm{Mn}-\mathrm{O}$ distances from the $\mathrm{O}$ trans to the N-heterocyclic carbene carbon $(2.34 \AA)$ are slightly longer than those $(2.23 \AA)$ from the $\mathrm{O}$ cis to the carbon, probably due to the strong donor property of the $\mathrm{N}$-heterocyclic carbene. Accordingly, the shorter Mn-O bond is associated with a longer carboxyl C-O bond. The 
average value (2.29 $\AA$ ) of the Mn-O distance is significantly longer than that of the bridging carboxyl group in $\left[\mathrm{Mn}_{2}(\mu-\mathrm{MeCOO})_{\mathrm{x}}\right]^{4-\mathrm{x}}$ system $(1.99-2.13 \AA)$ and also longer than that (av. $2.07 \AA$ ) of the chelating acetate group in $(\mathrm{MeCOO}) \mathrm{Mn}(\mathrm{CO})_{2}\left(\mathrm{PPh}_{3}\right)_{2} \cdot{ }^{30,31}$ The distance from the manganese atom to the central carbon atom of the acetate group ( $2.61 \AA)$ is in the nonbonding range. ${ }^{31}$

The C-Mn-C angle in 4 is $96.7^{\circ}$, which shows that the two N-heterocyclic carbenes are in a cis position. The Mn-C distance (2.25 $\AA$ ) is in the range $(2.20-2.27 \AA)$ of the $\mathrm{Mn}-\mathrm{C}(\mathrm{N}$ heterocyclic carbene) distances known and is slightly longer than those in $\mathbf{2}$ and $\mathbf{3}$.

Interestingly, both in-plane bending and out-of-plane bending of the N-heterocyclic carbenes are not observable in 4. The similar $\mathrm{N}(1)-\mathrm{C}(1)-\mathrm{Mn}(1)\left(129.3^{\circ}\right)$ and $\mathrm{N}(2)-\mathrm{C}(1)$ $\operatorname{Mn}(1)\left(126.7^{\circ}\right)$ angles do not support any in-plane bending of the N-heterocyclic carbenes.

Table 2. Selected bond lengths $(\AA)$ and bond angles $\left({ }^{\circ}\right)$ for compound 4

\begin{tabular}{lllr}
\hline $\mathrm{Mn}(1)-\mathrm{O}(1)$ & $2.343(2)$ & $\mathrm{C}(1)-\mathrm{Mn}(1)-\mathrm{O}(2 \mathrm{~A})$ & $97.34(8)$ \\
$\mathrm{Mn}(1)-\mathrm{O}(2)$ & $2.233(2)$ & $\mathrm{O}(2)-\mathrm{Mn}(1)-\mathrm{O}(2 \mathrm{~A})$ & $146.33(12)$ \\
$\mathrm{Mn}(1)-\mathrm{O}(1 \mathrm{~A})$ & $2.343(2)$ & $\mathrm{O}(2)-\mathrm{Mn}(1)-\mathrm{C}(1 \mathrm{~A})$ & $97.34(8)$ \\
$\mathrm{Mn}(1)-\mathrm{O}(2 \mathrm{~A})$ & $2.233(2)$ & $\mathrm{O}(2)-\mathrm{Mn}(1)-\mathrm{O}(1)$ & $56.92(8)$ \\
$\mathrm{Mn}(1)-\mathrm{C}(1)$ & $2.254(3)$ & $\mathrm{O}(2)-\mathrm{Mn}(1)-\mathrm{O}(1 \mathrm{~A})$ & $98.60(8)$ \\
$\mathrm{Mn}(1)-\mathrm{C}(6)$ & $2.612(3)$ & $\mathrm{O}(1)-\mathrm{Mn}(1)-\mathrm{C}(1 \mathrm{~A})$ & $87.69(9)$ \\
$\mathrm{Mn}(1)-\mathrm{C}(1 \mathrm{~A})$ & $2.254(3)$ & $\mathrm{O}(1)-\mathrm{Mn}(1)-\mathrm{O}(1 \mathrm{~A})$ & $93.65(12)$ \\
$\mathrm{Mn}(1)-\mathrm{C}(6 \mathrm{~A})$ & $2.612(3)$ & $\mathrm{O}(1)-\mathrm{Mn}(1)-\mathrm{O}(2 \mathrm{~A})$ & $98.60(8)$ \\
$\mathrm{O}(1)-\mathrm{C}(6)$ & $1.238(4)$ & $\mathrm{O}(1 \mathrm{~A})-\mathrm{Mn}(1)-\mathrm{O}(2 \mathrm{~A})$ & $56.92(8)$ \\
$\mathrm{O}(2)-\mathrm{C}(6)$ & $1.258(4)$ & $\mathrm{O}(1 \mathrm{~A})-\mathrm{Mn}(1)-\mathrm{C}(1 \mathrm{~A})$ & $161.79(9)$ \\
$\mathrm{N}(1)-\mathrm{C}(1)$ & $1.364(3)$ & $\mathrm{O}(2 \mathrm{~A})-\mathrm{Mn}(1)-\mathrm{C}(1 \mathrm{~A})$ & $104.91(8)$ \\
$\mathrm{N}(2)-\mathrm{C}(1)$ & $1.356(3)$ & $\mathrm{O}(1)-\mathrm{C}(6)-\mathrm{O}(2)$ & $122.0(3)$ \\
$\mathrm{C}(1)-\mathrm{Mn}(1)-\mathrm{C}(1 \mathrm{~A})$ & $96.68(13)$ & $\mathrm{N}(1)-\mathrm{C}(1)-\mathrm{N}(2)$ & $104.0(2)$ \\
$\mathrm{C}(1)-\mathrm{Mn}(1)-\mathrm{O}(1)$ & $161.79(9)$ & $\mathrm{N}(2)-\mathrm{C}(1)-\mathrm{Mn}(1)$ & $126.67(18)$ \\
$\mathrm{C}(1)-\mathrm{Mn}(1)-\mathrm{O}(1 \mathrm{~A})$ & $87.69(9)$ & $\mathrm{N}(1)-\mathrm{C}(1)-\mathrm{Mn}(1)$ & $129.32(18)$ \\
$\mathrm{C}(1)-\mathrm{Mn}(1)-\mathrm{O}(2)$ & $104.91(9)$ & & \\
\hline
\end{tabular}




\subsubsection{Solid-state Powder EPR Spectra of 2 - 4}

Manganese(II) complexes exhibit a great variety of EPR signals related to their structures. ${ }^{32}$ The $X$-band EPR spectra of complexes 2 - 4 were recorded at ambient temperature with powder samples. As expected, a strong resonance in complexes $\mathbf{2}$ and $\mathbf{3}$ is observed near $g_{\text {eff }}=4.3$ due to their tetrahedral geometry. ${ }^{33}$ In addition, compound 2 exhibits two shoulders to lower field and several weaker bands to higher field, while the spectrum of 3 is much simpler: another strong resonance $\left(g_{\text {eff }}=2\right)$ and a very weak one at high field. The spectrum of compound 4 exhibits a very strong band $\left(g_{\text {eff }}=2\right)$ and a weaker one (near $g_{\text {eff }}=$ 4.3) and has shoulders to higher and lower field of the main line. The spectrum of $\mathbf{4}$ is similar to that of complex $\mathrm{Mn}(o \text {-phen })_{2}(\mathrm{NCS})_{2}$, which has a very small $\mathrm{D}$ value (near zero) and a large $\lambda$ value (near $1 / 3$ ) ( $\mathrm{D}$ and $\lambda$ are zero-field splitting parameters). ${ }^{34}$ The spectrum is consistent with the symmetric structure of $\mathbf{4}$ and the cis arrangement of the two carbene ligands.

\subsection{Synthesis, Structure and Reactivity of Manganese Chlorides 7 - 10 Containing a Bulky $\beta$-Diketiminate Ligand}

In the past few years there is increasing interest in $\beta$-diketiminate ligands, especially those with bulky aryl groups at the nitrogen atoms, which have excellent steric and electronic properties to stabilize unusual metal sites. ${ }^{35} \mathrm{~A}$ variety of main group element, transition metal and lanthanide complexes containing such ligands have been synthesized and characterized, some of which have novel structures and good catalytic activities. ${ }^{35}$ For example, the first monomeric $\mathrm{Al}(\mathrm{I})$ compound $\mathrm{LAl}\left(\mathrm{L}=\mathrm{HC}(\mathrm{CMeNAr})_{2}, \mathrm{Ar}=2,6-i \mathrm{Pr}_{2} \mathrm{C}_{6} \mathrm{H}_{3}\right)$ as a stable carbene analogue was synthesized in our group. ${ }^{36}$ Very recently, an aluminium dihydroxide with terminal $\mathrm{OH}$ groups and the first terminal hydroxide containing alumoxane were also obtained using the same bulky ligand. ${ }^{37}$

In spite of the impressive results obtained by using $\beta$-diketiminate ligands now known, little work has appeared on manganese $\beta$-diketiminate complexes. Chlorides are normally the most common and available sources of manganese(II), however, manganese chlorides containing such ligands remain rare prior to this work. 


\subsubsection{Synthesis and Spectroscopic Characterization of Complexes 7 - 10}

The $\beta$-diketiminate lithium salt $\operatorname{LLi}\left(\mathrm{OEt}_{2}\right)(5)$ has been reported previously and widely used as a metathesis reagent. ${ }^{38}$ The preparation of LK (6) was described resulting from the reaction of $\mathrm{LH}$ with $\mathrm{KN}\left(\mathrm{SiMe}_{3}\right)_{2}$ in relatively low yield $(27 \%) .{ }^{39}$ Herein we report the convenient preparation of $\mathbf{5}$ as a crystalline solid in good yield (87\%) by the reaction of LH and $\mathrm{KH}$ in diethyl ether at room temperature (Scheme 3). ${ }^{1} \mathrm{H}$ NMR and elemental analyses are consistent with those of the literature. ${ }^{39}$ Compound $\mathbf{6}$ is stable under an inert atmosphere and can be kept for a long time without decomposition.

\section{Scheme 3}

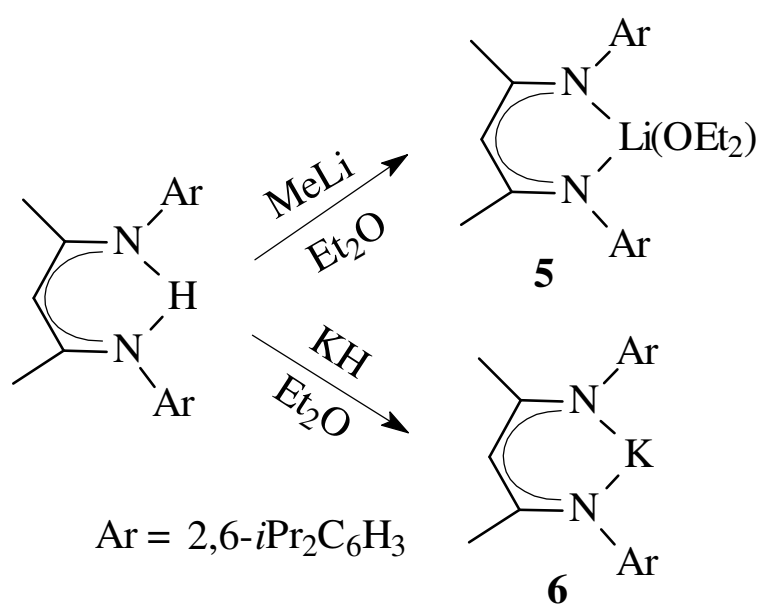

The reaction of $\mathbf{5}$ and anhydrous $\mathrm{MnCl}_{2}$ in diethyl ether afforded the metalate complex $\operatorname{LMn}(\mu-\mathrm{Cl})_{2} \operatorname{Li}\left(\mathrm{OEt}_{2}\right)_{2}$ (7) in high yield (Scheme 4). Attempts to remove the coordinated lithium salt from the manganese center were unsuccessful. Expectedly, the reaction of $\mathrm{MnCl}_{2}$ with one equiv. of 6 in diethyl ether readily gave the dimeric compound [LMn $(\mu-$ $\mathrm{Cl})]_{2}(\mathbf{8})$ in high yield. Attempts to prepare the di- $\beta$-diketiminate complex by using 2 equiv. of 5 or $\mathbf{6}$ were unsuccessful. However, the analogous reaction of $\mathbf{6}$ and $\mathrm{MnCl}_{2}(\mathrm{THF})_{1.5}$ in THF resulted in the unexpected formation of the trinuclear complex $\operatorname{LMn}(\mu$ $\mathrm{Cl})_{2} \mathrm{Mn}(\mathrm{THF})_{2}(\mu-\mathrm{Cl})_{2} \mathrm{MnL}(9)$ in good yield, although a ratio of 1:1 of the starting materials was employed (Scheme 5). 


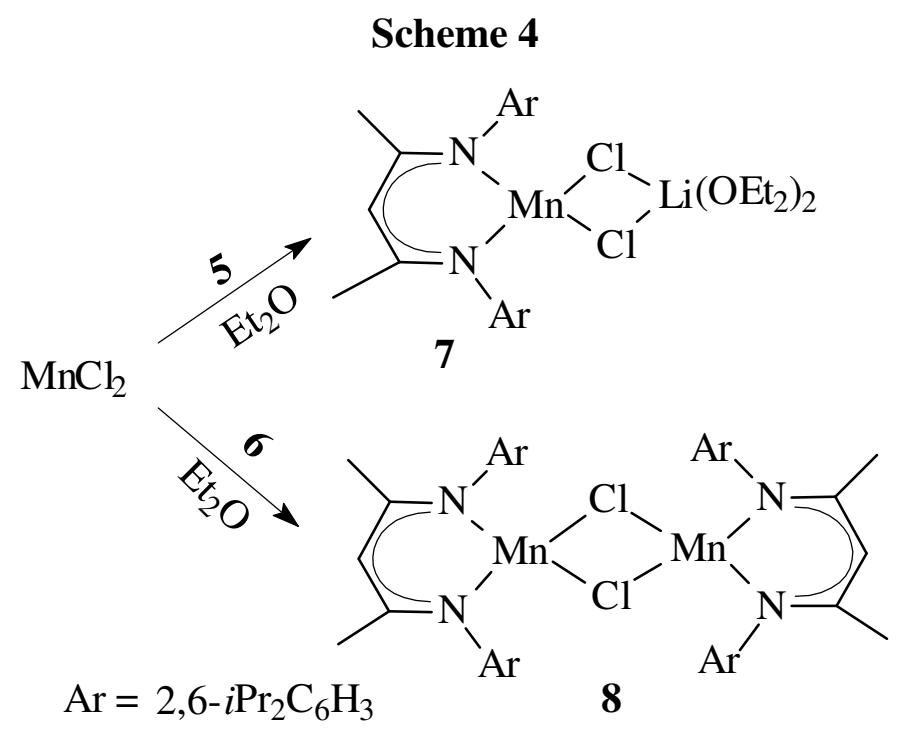

Scheme 5

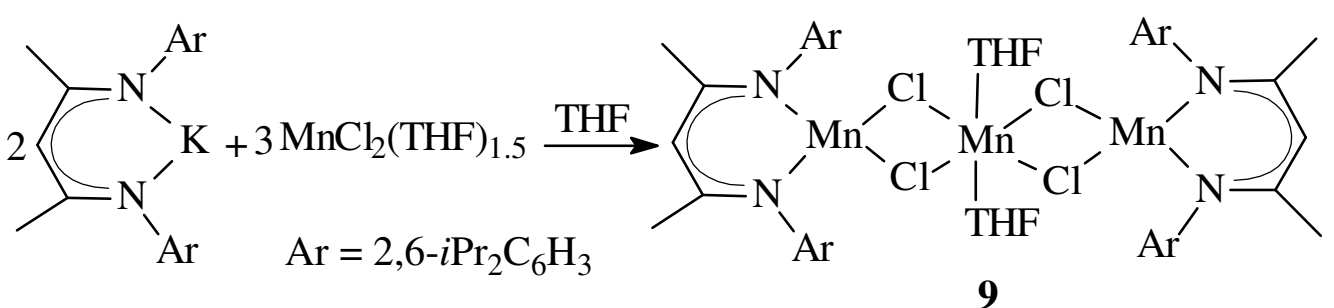

When the N-heterocyclic carbene $[\mathrm{C}(\mathrm{Me}) \mathrm{N}(i \mathrm{Pr})]_{2} \mathrm{C}(\mathbf{1})$ was employed as the acceptor for the proton of $\mathrm{LH}$, the novel ionic compound $\left[\mathrm{LMnCl}_{2}\right]\left[\{\mathrm{C}(\mathrm{Me}) \mathrm{N}(i \mathrm{Pr})\}_{2} \mathrm{CH}\right](\mathbf{1 0})$ was easily obtained as a yellow crystalline solid in high yield from the reaction of $\mathrm{LH}, \mathrm{MnCl}_{2}(\mathrm{THF})_{1.5}$, and 1 in THF at room temperature. However, no reaction occurs when in either case LH and 1 or $\mathrm{LH}$ and $\mathrm{MnCl}_{2}(\mathrm{THF})_{1.5}$ were mixed in THF at room temperature. Therefore we suppose that the process for the formation of $\mathbf{1 0}$ is a concerted one and may proceed through the intermediate 10a (Scheme 6).

Complexes 7 - $\mathbf{1 0}$ are crystalline yellow solids soluble in THF. These complexes were characterized by elemental analyses, EI-MS and IR. The EI-MS of 7 and $\mathbf{9}$ show absence of the molecular ion peak and $[\mathrm{LMnCl}]^{+} \mathrm{m} / \mathrm{z} 507$ appears as the most intense ion. The molecular ion peak of the dimer $\mathbf{8}$ in the EI mass spectrum is not observed, whereas half of the molecular mass $[1 / 2 \mathrm{M}]^{+}$appears at $\mathrm{m} / \mathrm{z}, 507$ as the most intense peak. Interestingly, the ion $[\mathrm{M}-\mathrm{H}]^{+}$in the mass spectrum of $\mathbf{1 0}$ can be seen albeit with low intensity $(2 \%)$, followed by $[\mathrm{LMnCl}]^{+} \mathrm{m} / z 507(43 \%)$ and $\left[\{\mathrm{C}(\mathrm{Me}) \mathrm{N}(i \mathrm{Pr})\}_{2} \mathrm{CH}\right]^{+} 181(52 \%)$. 


\section{Scheme 6}

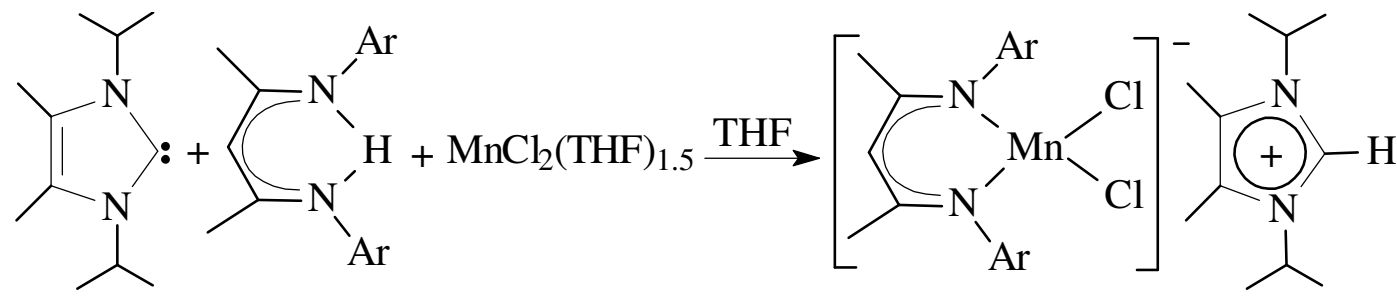

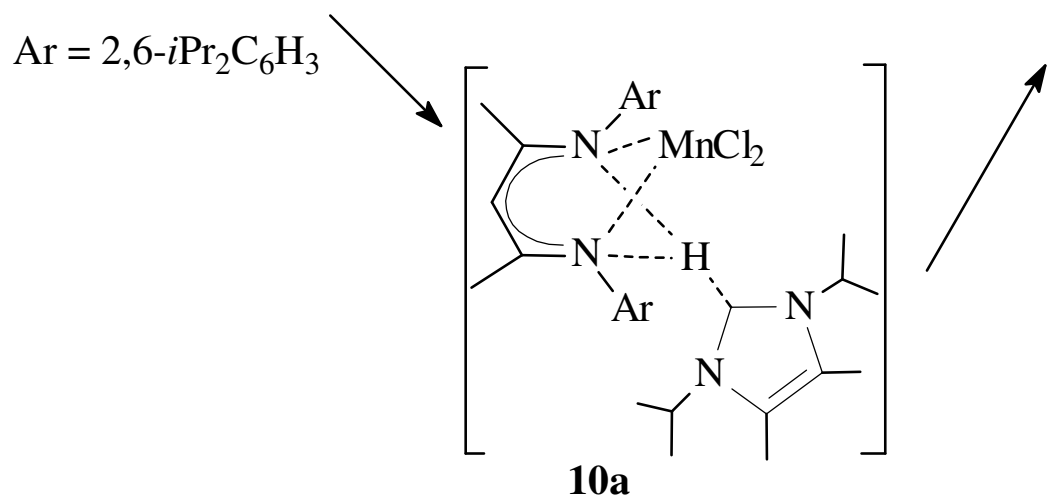

10

\subsubsection{X-ray Solid-state Structural Analyses of Complexes 7 - 10}

The X-ray solid-state structural analyses reveal that $\mathrm{LMn}(\mu-\mathrm{Cl})_{2} \mathrm{Li}_{(}\left(\mathrm{OEt}_{2}\right)_{2}$ (7) is monomeric, $[\mathrm{LMn}(\mu-\mathrm{Cl})]_{2} \quad(8)$ is dimeric, and $\mathrm{LMn}(\mu-\mathrm{Cl})_{2} \mathrm{Mn}(\mathrm{THF})_{2}(\mu-\mathrm{Cl})_{2} \mathrm{MnL}$ (9) trinuclear in the solid state (Figures 4 - 6). [ $\left.\mathrm{LMnCl}_{2}\right]\left[\{\mathrm{C}(\mathrm{Me}) \mathrm{N}(i \mathrm{Pr})\}_{2} \mathrm{CH}\right](\mathbf{1 0})$ crystallizes as separated anion $\left[\mathrm{LMnCl}_{2}\right]^{-}$and cation $\left[\{\mathrm{C}(\mathrm{Me}) \mathrm{N}(i \mathrm{Pr})\}_{2} \mathrm{CH}\right]^{+}$. The structure of the anion is shown in Figure 7.

In the compounds 7, 8 and 10, each manganese atom is bound to two nitrogen atoms of the chelating ligand and two chlorine atoms in a distorted tetrahedral geometry. The molecule of 9 consists of a linear trinuclear compound with four bridging chlorine atoms and two chelating ligands adopting a symmetric structure, which, in fact, is one $\mathrm{MnCl}_{2}(\mathrm{THF})_{2}$ molecule captured by the dimer $[\operatorname{LMn}(\mu-\mathrm{Cl})]_{2}(\mathbf{8})$. The central $\operatorname{Mn}(2)$ atom in $\mathbf{9}$ adopts a distorted octahedral coordination with two THF molecules in trans position, while the other two manganese atoms achieve a distorted tetrahedral geometry. The backbone of the chelating ligand is nearly planar and the manganese atoms in these compounds are out of the $\mathrm{C}_{3} \mathrm{~N}_{2}$ planes $(0.45 \AA$ in $7,0.47 \AA$ in $\mathbf{8}, 0.36 \AA$ in 9 and $0.70 \AA$ in $\mathbf{1 0})$. The order of the N-Mn$\mathrm{N}$ angles is $\mathbf{9}\left(91.3^{\circ}\right)<\mathbf{1 0}\left(91.6^{\circ}\right)<\mathbf{7}\left(92.2^{\circ}\right)<\mathbf{8}\left(92.8^{\circ}\right)$, while the order of the $\mathrm{Mn}-\mathrm{N}$ bond lengths is $\mathbf{1 0}$ (av. $2.11 \AA$ ) > 7 (av. $2.08 \AA$ ), 8 (av. $2.08 \AA$ ) and 9 (2.08 $\AA$ ), which indicates that the metal center in $\mathbf{1 0}$ is more weakly bonded to the chelating ligand due to the two terminal $\mathrm{Mn}-\mathrm{Cl}$ bonds. The terminal $\mathrm{Mn}-\mathrm{Cl}$ distances (av. $2.36 \AA$ ) in $\mathbf{1 0}$ are comparable to 
those of the bridging ones in 7 (av. $2.38 \AA$ ), 8 (av. $2.33 \AA$ ) and 9 (av. $2.40 \AA$ ) due to the anionic character of the $\mathrm{LMnCl}_{2}$ in $\mathbf{1 0}$. Accordingly, the $\mathrm{Cl}-\mathrm{Mn}-\mathrm{Cl}$ angle in $\mathbf{1 0}\left(112.0^{\circ}\right)$ is significantly larger than those in $7\left(96.2^{\circ}\right), 8\left(90.5^{\circ}\right)$ and $9\left(91.4^{\circ}\right)$.

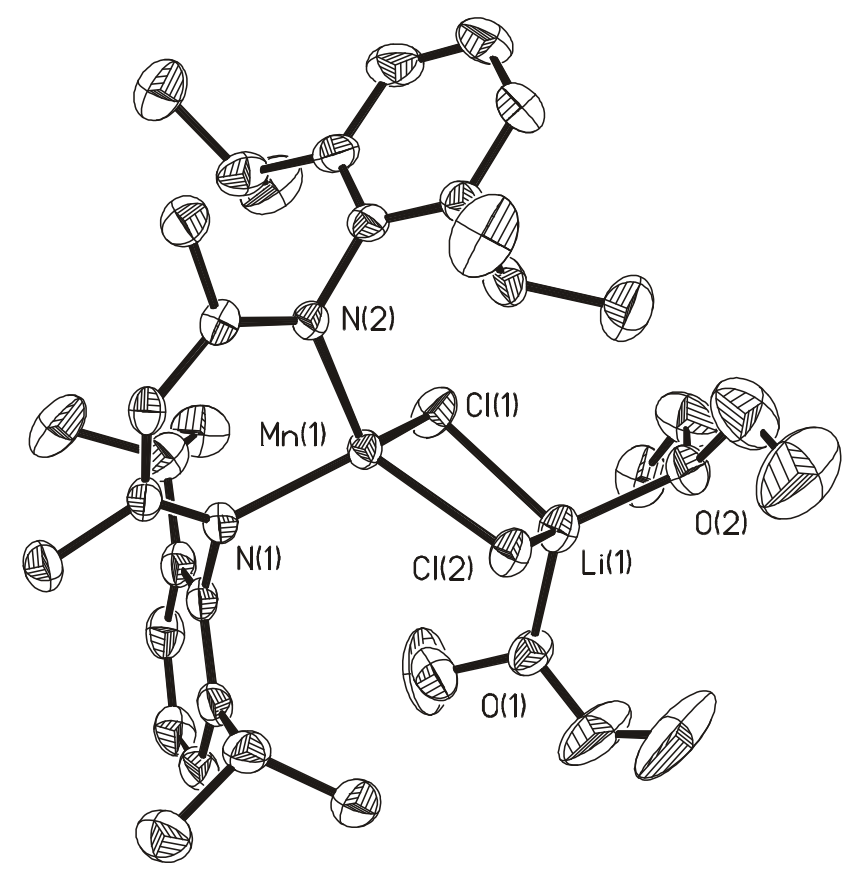

Figure 4. Molecular structure of 7 (50\% probability ellipsoids). Hydrogen atoms are omitted for clarity.

The lithium atom in $\mathbf{7}$ is connected by two bridging chlorides and two oxygen atoms of two coordinated ether molecules in a distorted tetrahedral geometry. The structure is like that of the alkali metal adducts of the $\beta$-diketiminate metal complexes of general formula $\operatorname{LM}(\mu$ $\mathrm{X}_{2} \mathrm{Li}(\text { ether })_{2}(\mathrm{X}=\mathrm{Cl}, \mathrm{I}) .{ }^{20 \mathrm{a}, 40} \mathrm{The} \mathrm{Li}-\mathrm{Cl}$ and $\mathrm{Li}-\mathrm{O}$ distances (av. 2.38 and $1.96 \AA$, respectively) are similar to those found in $\mathrm{LM}(\mu-\mathrm{Cl})_{2} \mathrm{Li}(\mathrm{THF})_{2}(\mathrm{M}=\mathrm{Fe}(\mathrm{II}), \mathrm{Co}(\mathrm{II})) .^{20 \mathrm{a}, 40 \mathrm{c}}$

The central core of $\mathbf{8}$ contains an ideal planar four-membered $\mathrm{Mn}_{2} \mathrm{Cl}_{2}$ ring, which bisects and is perpendicular $\left(89.2^{\circ}\right)$ to the two chelating ligands around it. The distance between two manganese atoms is $3.28 \AA$, which can be compared to that in $[\operatorname{LMn}(\mu-\mathrm{I})]_{2}{ }^{41}$ (18) $(3.62 \AA)$ and is out of the range of a $\mathrm{Mn}-\mathrm{Mn}$ bond. The internal $\mathrm{Cl}(1)-\mathrm{Mn}(2)-\mathrm{Cl}(2)$ and $\mathrm{Mn}-\mathrm{Cl}-\mathrm{Mn}$ angles (84.7 and av. $92.0^{\circ}$, respectively) in 9 result in the Mn-Mn distances (3.56 $⿱$ ) , which are longer than that observed in $\mathbf{8}$. Similar to that in $\mathbf{8}$, the two bridging $\mathrm{Mn}_{2} \mathrm{Cl}_{2}$ rings in 9 are ideally coplanar, which bisect and are perpendicular $\left(90.0^{\circ}\right)$ to the two chelating ligands 
around them. The structure of the cation $\left[\{\mathrm{C}(\mathrm{Me}) \mathrm{N}(i \mathrm{Pr})\}_{2} \mathrm{CH}\right]^{+}$in $\mathbf{1 0}$ is similar to that in $\left[\{\mathrm{C}(\mathrm{Me}) \mathrm{N}(\mathrm{Me})\}_{2} \mathrm{CH}\right]\left[\mathrm{Ph}_{5} \mathrm{C}_{5}\right] .{ }^{42}$

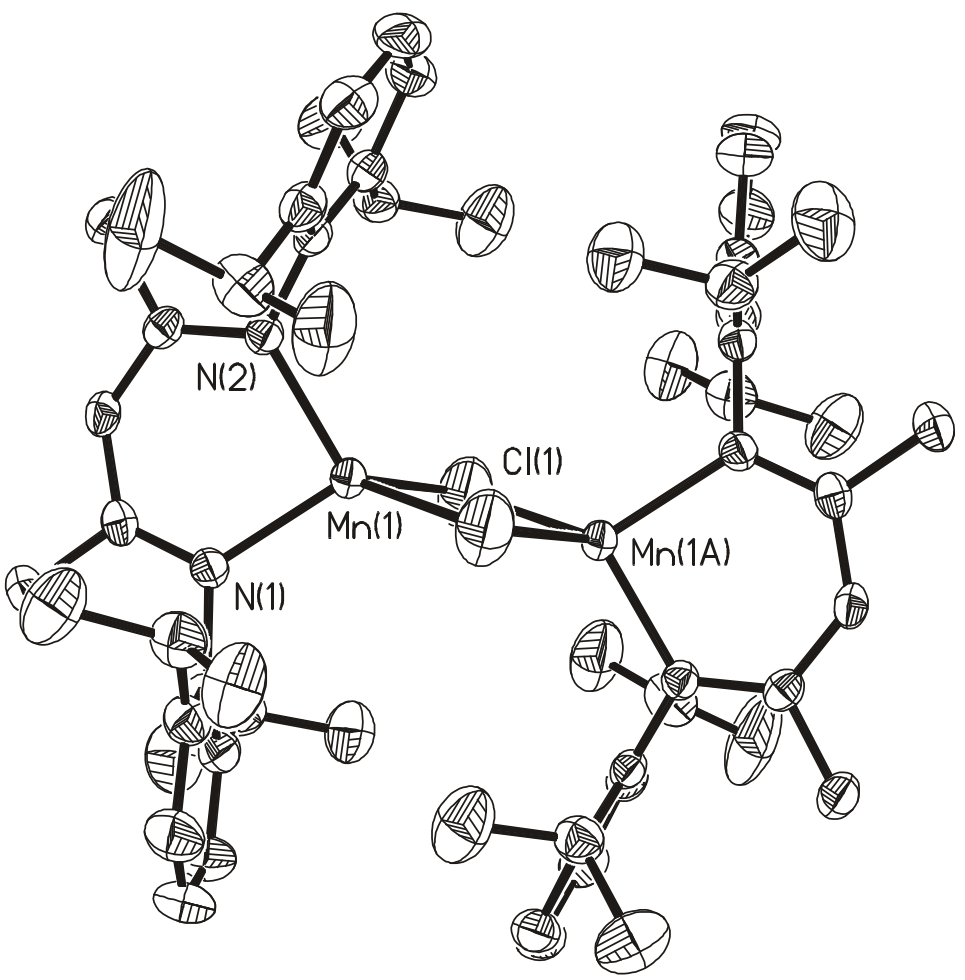

Figure 5. Molecular structure of $\mathbf{8}$ (50\% probability ellipsoids). Hydrogen atoms are omitted for clarity.

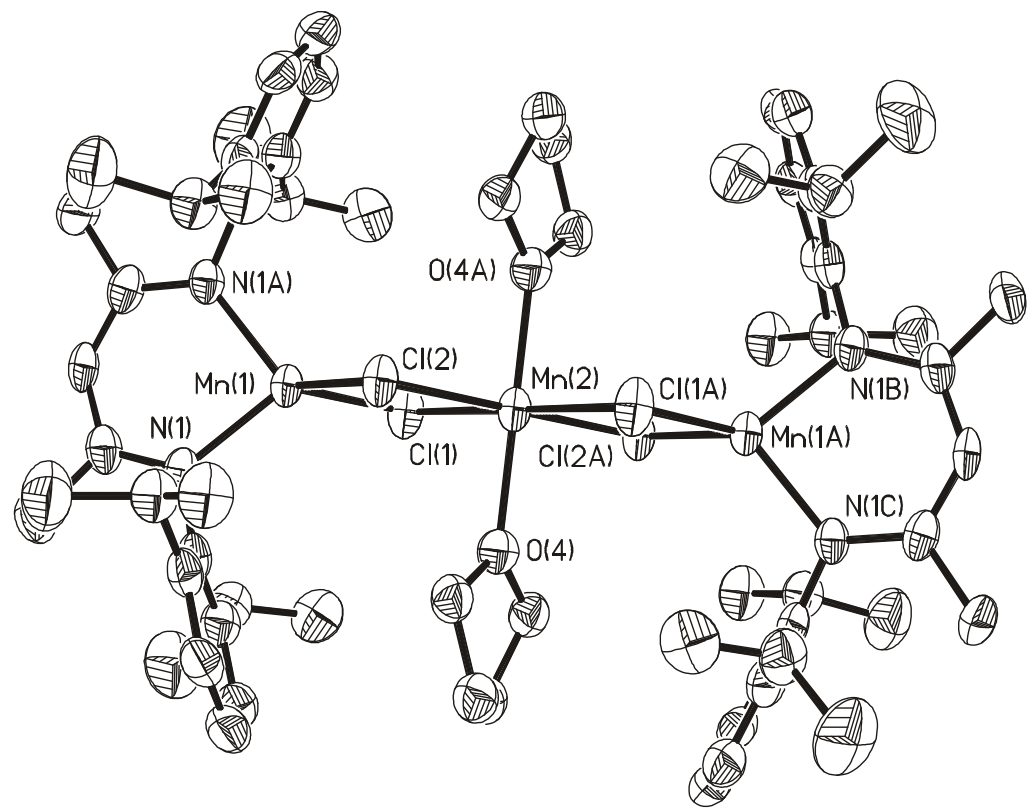

Figure 6. Molecular structure of 9 (50\% probability ellipsoids). Hydrogen atoms are omitted for clarity. 


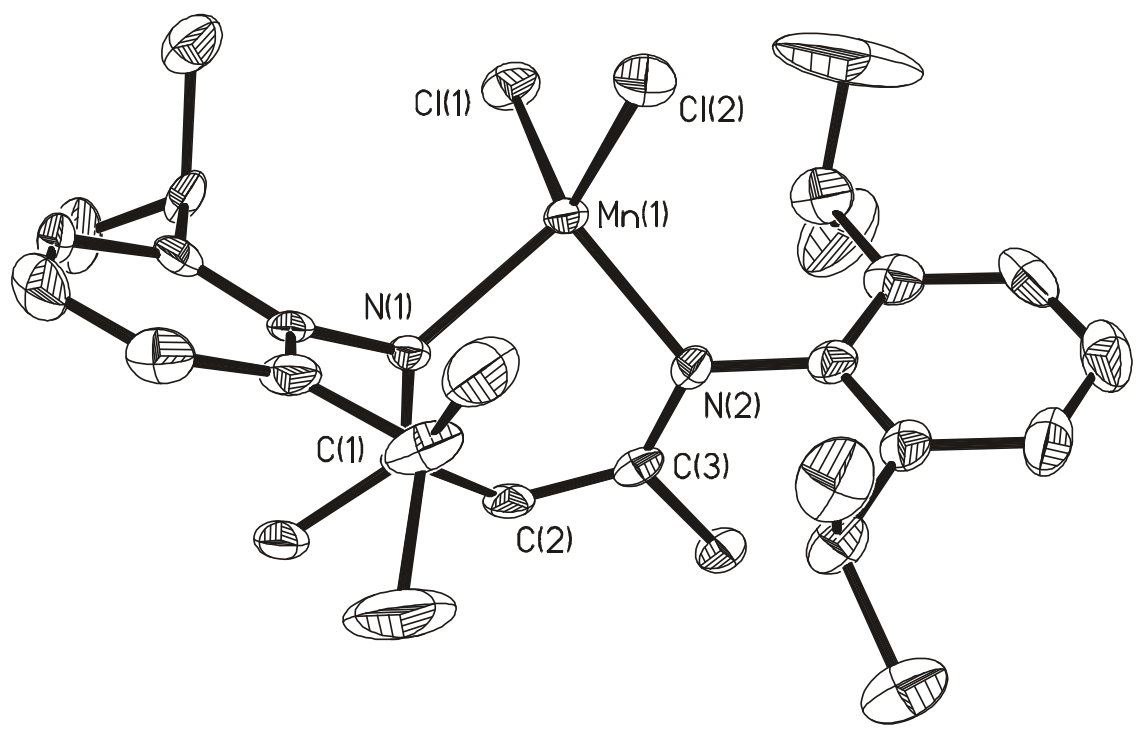

Figure 7. Crystal structure of the anion of $\mathbf{1 0}$ (50\% probability ellipsoids).

Hydrogen atoms are omitted for clarity.

Table 3. Selected bond lengths $(\AA)$ and bond angles $\left(^{\circ}\right)$ for compounds $\mathbf{7}$ and $\mathbf{8}$

\begin{tabular}{lllr}
\hline \multicolumn{3}{c}{ Compound 7} \\
\hline $\mathrm{Mn}(1)-\mathrm{N}(1)$ & $2.083(2)$ & $\mathrm{N}(1)-\mathrm{Mn}(1)-\mathrm{N}(2)$ & $92.21(8)$ \\
$\mathrm{Mn}(1)-\mathrm{N}(2)$ & $2.072(2)$ & $\mathrm{N}(1)-\mathrm{Mn}(1)-\mathrm{Cl}(1)$ & $118.99(7)$ \\
$\mathrm{Mn}(1)-\mathrm{Cl}(1)$ & $2.3688(11)$ & $\mathrm{N}(2)-\mathrm{Mn}(1)-\mathrm{Cl}(1)$ & $116.72(7)$ \\
$\mathrm{Mn}(1)-\mathrm{Cl}(2)$ & $2.3887(10)$ & $\mathrm{Cl}(1)-\mathrm{Mn}(1)-\mathrm{Cl}(2)$ & $96.10(3)$ \\
$\mathrm{Li}(1)-\mathrm{Cl}(1)$ & $2.371(5)$ & $\mathrm{N}(1)-\mathrm{Mn}(1)-\mathrm{Cl}(2)$ & $115.29(6)$ \\
$\mathrm{Li}(1)-\mathrm{Cl}(2)$ & $2.383(5)$ & $\mathrm{N}(2)-\mathrm{Mn}(1)-\mathrm{Cl}(2)$ & $119.48(6)$ \\
$\mathrm{Li}(1)-\mathrm{O}(1)$ & $1.948(6)$ & $\mathrm{Cl}(1)-\mathrm{Li}(1)-\mathrm{Cl}(2)$ & $96.20(17)$ \\
$\mathrm{Li}(1)-\mathrm{O}(2)$ & $1.975(6)$ & $\mathrm{O}(1)-\mathrm{Li}(1)-\mathrm{O}(2)$ & $114.7(3)$ \\
\hline & & $\mathrm{Compound} \mathbf{8}$ & \\
\hline $\mathrm{Mn}(1)-\mathrm{N}(1)$ & $2.0830(9)$ & $\mathrm{N}(1)-\mathrm{Mn}(1)-\mathrm{N}(2)$ & $92.80(3)$ \\
$\mathrm{Mn}(1)-\mathrm{N}(2)$ & $2.0819(10)$ & $\mathrm{N}(1)-\mathrm{Mn}(1)-\mathrm{Cl}(1)$ & $117.09(3)$ \\
$\mathrm{Mn}(1)-\mathrm{Cl}(1)$ & $2.3422(7)$ & $\mathrm{N}(2)-\mathrm{Mn}(1)-\mathrm{Cl}(1)$ & $118.34(3)$ \\
$\mathrm{Mn}(1)-\mathrm{Cl}(1 \mathrm{~A})$ & $2.3093(6)$ & $\mathrm{Cl}(1)-\mathrm{Mn}(1)-\mathrm{Cl}(1 \mathrm{~A})$ & $90.49(2)$ \\
$\mathrm{Mn}(1 \mathrm{~A})-\mathrm{Cl}(1)$ & $2.3093(6)$ & $\mathrm{N}(1)-\mathrm{Mn}(1)-\mathrm{Cl}(1 \mathrm{~A})$ & $119.74(3)$ \\
$\mathrm{Mn}(1)-\mathrm{Mn}(1 \mathrm{~A})$ & 3.275 & $\mathrm{~N}(2)-\mathrm{Mn}(1)-\mathrm{Cl}(1 \mathrm{~A})$ & $120.93(3)$ \\
\hline
\end{tabular}


Table 4. Selected bond lengths $(\AA)$ and bond angles $\left({ }^{\circ}\right)$ for compounds $\mathbf{9}$ and $\mathbf{1 0}$

\begin{tabular}{lllr}
\hline \multicolumn{3}{c}{ Compound 9 } \\
\hline $\mathrm{Mn}(1)-\mathrm{N}(1)$ & $2.077(5)$ & $\mathrm{N}(1)-\mathrm{Mn}(1)-\mathrm{N}(1 \mathrm{~A})$ & $91.3(2)$ \\
$\mathrm{Mn}(1)-\mathrm{N}(1 \mathrm{~A})$ & $2.077(4)$ & $\mathrm{N}(1)-\mathrm{Mn}(1)-\mathrm{Cl}(1)$ & $120.65(13)$ \\
$\mathrm{Mn}(1)-\mathrm{Cl}(1)$ & $2.391(2)$ & $\mathrm{N}(1)-\mathrm{Mn}(1)-\mathrm{Cl}(2)$ & $117.80(12)$ \\
$\mathrm{Mn}(1)-\mathrm{Cl}(2)$ & $2.412(2)$ & $\mathrm{Cl}(1)-\mathrm{Mn}(1)-\mathrm{Cl}(2)$ & $91.36(7)$ \\
$\mathrm{Mn}(2)-\mathrm{Cl}(1)$ & $2.576(2)$ & $\mathrm{O}(4)-\mathrm{Mn}(2)-\mathrm{O}(4 \mathrm{~A})$ & 180.0 \\
$\mathrm{Mn}(2)-\mathrm{Cl}(2)$ & $2.5266(19)$ & $\mathrm{O}(4)-\mathrm{Mn}(2)-\mathrm{Cl}(2)$ & 90.0 \\
$\mathrm{Mn}(2)-\mathrm{O}(4)$ & $2.200(6)$ & $\mathrm{O}(4)-\mathrm{Mn}(2)-\mathrm{Cl}(1)$ & 90.0 \\
$\mathrm{Mn}(1)-\mathrm{Mn}(2)$ & 3.564 & $\mathrm{Cl}(1)-\mathrm{Mn}(2)-\mathrm{Cl}(2)$ & $84.65(6)$ \\
\hline & & $\mathrm{Compound} \mathbf{1 0}$ & \\
\hline $\mathrm{Mn}(1)-\mathrm{N}(1)$ & $2.102(2)$ & $\mathrm{N}(1)-\mathrm{Mn}(1)-\mathrm{N}(2)$ & $91.64(8)$ \\
$\mathrm{Mn}(1)-\mathrm{N}(2)$ & $2.111(2)$ & $\mathrm{N}(1)-\mathrm{Mn}(1)-\mathrm{Cl}(1)$ & $107.84(6)$ \\
$\mathrm{Mn}(1)-\mathrm{Cl}(1)$ & $2.3890(11)$ & $\mathrm{N}(2)-\mathrm{Mn}(1)-\mathrm{Cl}(1)$ & $109.42(7)$ \\
$\mathrm{Mn}(1)-\mathrm{Cl}(2)$ & $2.3370(10)$ & $\mathrm{Cl}(1)-\mathrm{Mn}(1)-\mathrm{Cl}(2)$ & $112.00(4)$ \\
\hline
\end{tabular}

\subsubsection{Reactivity of Compound 8 and its Organomanganese Derivatives 11 - 13 of Type $\operatorname{LMnR}(\mathrm{R}=\mathrm{Cp}, \mathrm{Me}$ and Ph$)$}

The substitution reactions of $\mathbf{8}$ with some nucleophiles were investigated in order to prepare organomanganese(II) complexes. Treatment of 8 with $\mathrm{CpNa}, \mathrm{MeLi}$ and $\mathrm{PhLi}$, respectively, resulted in the formation of the complexes $\operatorname{LMnCp}(\mathrm{THF})(\mathbf{1 1}),[\mathrm{LMn}(\mu-\mathrm{Me})]_{2}$ (12) and LMnPh (13) (Scheme 7). The monocyclopentadienyl manganese(II) compound 11 was readily obtained as yellow crystals from the reaction of 8 and 2 equiv. of $\mathrm{CpNa}$ in THF in high yield. Compound $\mathbf{1 1}$ is a rare example of a half-sandwich manganese(II) complex with the metal center of 17 valence electrons. ${ }^{43}$ The addition of MeLi and PhLi, respectively, to $\mathbf{8}$ in toluene at low temperature smoothly provided the dimeric compound $\mathbf{1 2}$ and the monomer 13 in moderate yields. However, the successful isolation of pure 12 and $\mathbf{1 3}$ was not easy due to the difficult removal of small amounts of unreacted starting material $\mathbf{8}$, so it requires several purification steps. The RLi reagents should be in some excess due to the stoichiometric amounts given in scheme 7. Recrystallization of the product from pentane has to be repeated. The reaction of $\mathbf{8}$ with $n \mathrm{BuLi}$, however, resulted in a preciptate of a manganese mirror and LH, confirmed by EI-MS and ${ }^{1} \mathrm{H}$ NMR. The proposed mechanism for this reaction is obviously the direct intramolecular elimination of the alkyl group and the 
chelating ligand. A similar decomposition pathway was suggested for various dialkyl Mn(II) species. $^{44}$

Complexes 11 - 13 are crystalline yellow solids, which are sensitive to air or moisture and were handled in a glove-box under purified nitrogen. Below the corresponding melting points of these compounds $\left(210-212{ }^{\circ} \mathrm{C}\right.$ for $\mathbf{1 1}, 190-192{ }^{\circ} \mathrm{C}$ for $\mathbf{1 2}$ and $230-232{ }^{\circ} \mathrm{C}$ for 13), no decomposition was observed. In the EI-MS of 11, [LMnCp] ${ }^{+}$appears at $\mathrm{m} / z$ 537 as the most intense peak without the coordinated solvent, followed by $m / z 472$ [LMn] ${ }^{+}(92 \%)$. EI-MS of 12 shows that the molecular peak $\mathrm{M}^{+}$is absent, however, half of the molecular mass $[\mathrm{LMnMe}]^{+}$is observed $(\mathrm{m} / \mathrm{z}, 487,6 \%)$ and the most intense peak $(\mathrm{m} / \mathrm{z}, 472)$ was assigned to $[\mathrm{LMn}]^{+}$. For $13, \mathrm{M}^{+}$was observed at $\mathrm{m} / z$ $549(3 \%)$, followed by $\left[\mathrm{M}-\mathrm{C}_{6} \mathrm{H}_{6}\right]^{+}(\mathrm{m} / \mathrm{z}$ 471) as the most intense peak.

Scheme 7

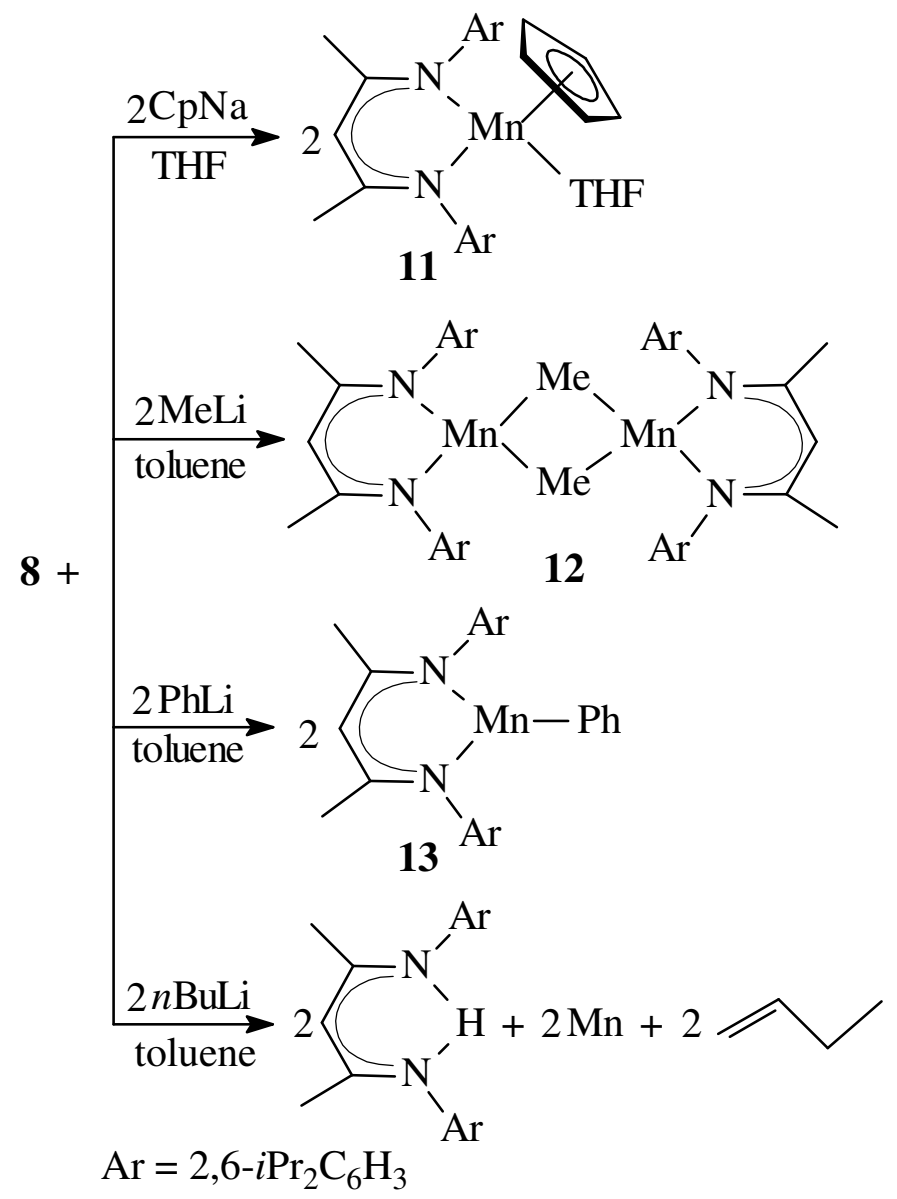

The molecular structure of $\mathbf{1 1}$ is shown in Figure 8. Compound $\mathbf{1 1}$ is monomeric with the $\mathrm{Cp}$ coordinated to the manganese center and crystallizes in the orthorhombic space group $P 2{ }_{1} 22_{1} 2_{1}$. The metal center has a pseudotetrahedral geometry and is surrounded by the 
cyclopentadienyl ring, the oxygen atom of the coordinated THF and two nitrogen atoms of the chelating ligand. The Mn-C distances (2.42 - $2.58 \AA)$ are in the range of those found in $\left[\mathrm{MeC}_{5} \mathrm{H}_{4} \operatorname{MnPEt}_{3}(\mu-\mathrm{X})\right]_{2}(\mathrm{X}=\mathrm{Cl}, \mathrm{Br}, \mathrm{I})(2.40-2.63 \AA)^{43}$ and $\operatorname{CpMnTMEDA}\left(\eta^{1}-\mathrm{Cp}\right)(2.44-$ $2.57 \AA^{45}$ The Mn-N distances (av. $2.13 \AA$ ) in $\mathbf{1 1}$ are the longest and the N-Mn-N angle $(90.3)^{\circ}$ is the smallest among those in complexes $\mathbf{7}-\mathbf{1 3}$, which is in agreement with the higher coordination number of manganese. The $\mathrm{Cp}$, the ligand plane and the THF plane are nearly orthogonal to each other.

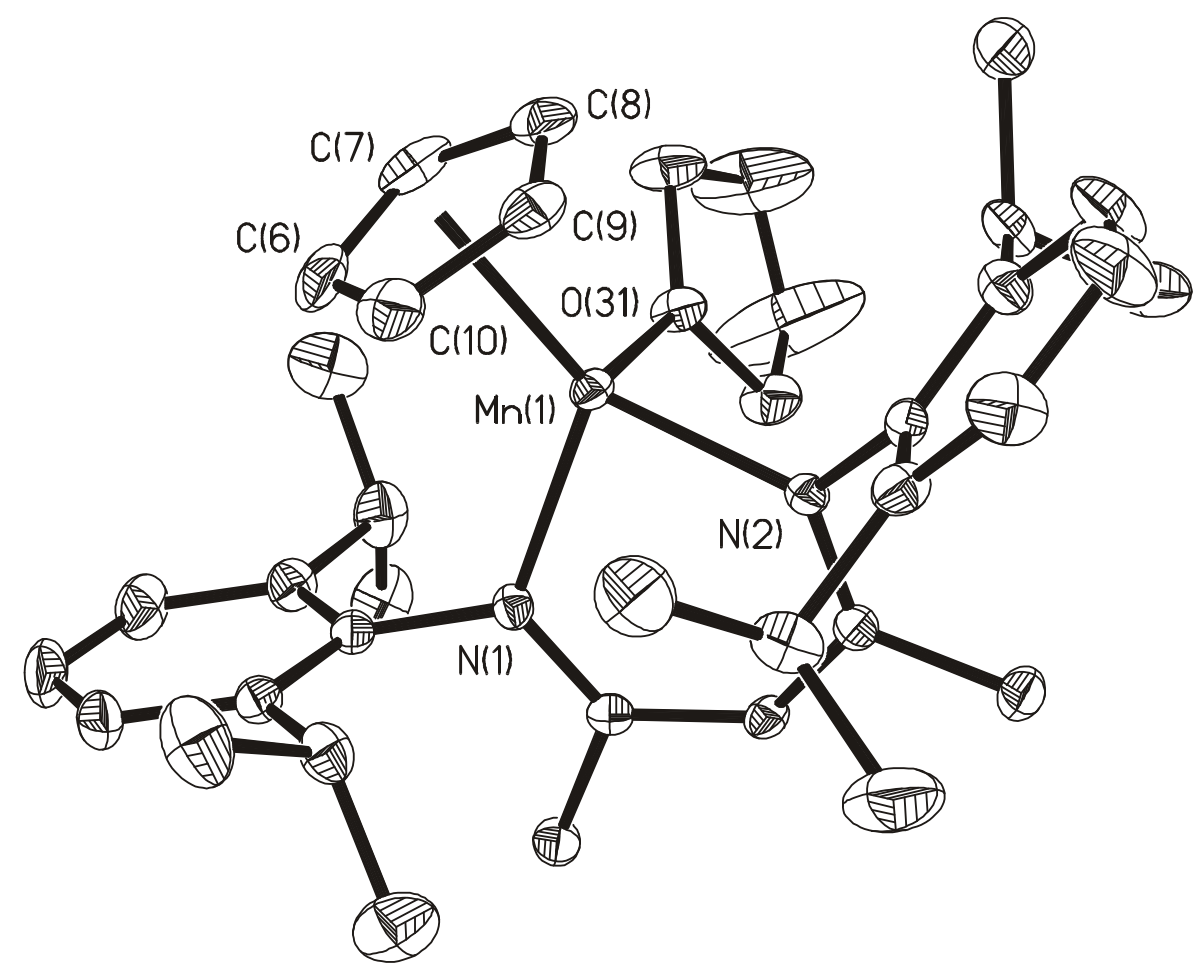

Figure 8. Molecular structure of $\mathbf{1 1}$ (50\% probability ellipsoids). Hydrogen atoms are omitted for clarity.

Table 5. Selected bond lengths $(\AA)$ and bond angles $\left({ }^{\circ}\right)$ for compound 11

\begin{tabular}{lllr}
\hline $\mathrm{Mn}(1)-\mathrm{N}(1)$ & $2.1242(15)$ & $\mathrm{N}(1)-\mathrm{Mn}(1)-\mathrm{N}(2)$ & $90.26(5)$ \\
$\mathrm{Mn}(1)-\mathrm{N}(2)$ & $2.1306(15)$ & $\mathrm{N}(1)-\mathrm{Mn}(1)-\mathrm{O}(31)$ & $97.69(5)$ \\
$\mathrm{Mn}(1)-\mathrm{O}(31)$ & $2.2787(12)$ & $\mathrm{N}(2)-\mathrm{Mn}(1)-\mathrm{O}(31)$ & $97.60(6)$ \\
$\mathrm{Mn}(1)-\mathrm{C}(6)$ & $2.547(2)$ & $\mathrm{N}(1)-\mathrm{Mn}(1)-\mathrm{C}(6)$ & $96.96(6)$ \\
$\mathrm{Mn}(1)-\mathrm{C}(7)$ & $2.442(2)$ & $\mathrm{N}(2)-\mathrm{Mn}(1)-\mathrm{C}(6)$ & $144.79(7)$ \\
$\mathrm{Mn}(1)-\mathrm{C}(8)$ & $2.419(2)$ & $\mathrm{O}(31)-\mathrm{Mn}(1)-\mathrm{C}(6)$ & $115.34(6)$ \\
$\mathrm{Mn}(1)-\mathrm{C}(9)$ & $2.5088(19)$ & $\mathrm{N}(1)-\mathrm{Mn}(1)-\mathrm{C}(7)$ & $120.33(7)$ \\
$\mathrm{Mn}(1)-\mathrm{C}(10)$ & $2.5778(19)$ & $\mathrm{N}(2)-\mathrm{Mn}(1)-\mathrm{C}(7)$ & $147.88(7)$ \\
\hline
\end{tabular}


Compound $\mathbf{1 2}$ is the first structurally characterized manganese alkyl complex containing bridging methyl groups. The solid-state structure of $\mathbf{1 2}$ (Figure 9) shows that the manganese centers have a distorted tetrahedral geometry. The backbone of the chelating ligand is nearly planar and the manganese atom is out of this plane $(0.56 \AA)$. The central core contains an ideally planar four-membered $\mathrm{Mn}_{2} \mathrm{C}_{2}$ ring, which bisects and is perpendicular $\left(89.5^{\circ}\right)$ to the two chelating ligands around it. The distance between two manganese atoms $(2.81 \AA)$ indicates a weak interaction rather than a strong Mn-Mn bond. ${ }^{13,46,47}$ The distance is comparable to that of the similar $\mathrm{Mn}_{2} \mathrm{C}_{2}$ core reported in the literature such as those in $\mathrm{Mn}_{2}\left(\mathrm{CH}_{2} \mathrm{C}_{6} \mathrm{H}_{4} \mathrm{NMe}_{2}\right)_{4}{ }^{47} \quad(2.81 \quad \AA), \quad \mathrm{Mn}_{2}\left(\mathrm{CH}_{2} \mathrm{SiMe}_{3}\right)_{4}\left(\mathrm{PMe}_{3}\right)_{2}{ }^{48} \quad(2.77 \quad \AA) \quad$ and $\mathrm{Mn}_{2}\left(\mathrm{CH}_{2} \mathrm{CMe}_{2} \mathrm{Ph}\right)_{4}{ }^{46}(2.72 \AA)$. The Mn-C bond length (av. $2.27 \AA$ ) is in the range of those $(2.22 \text { - } 2.28 \AA \text { ) in the manganates [Li(TMEDA) }]_{2}\left[\mathrm{MnR}_{4}\right]\left(\mathrm{R}=\mathrm{Me}, \mathrm{Et}, \mathrm{Bu}, \mathrm{CH}_{2} \mathrm{SiMe}_{3}\right){ }^{46,49}$

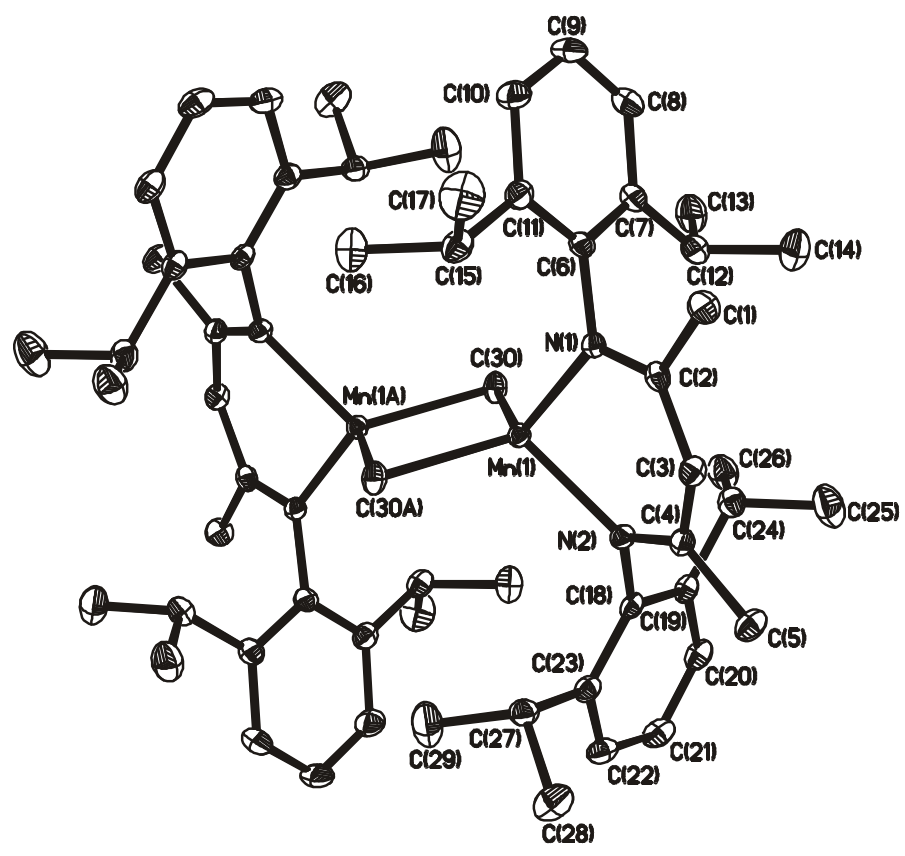

Figure 9. Molecular structure of $\mathbf{1 2}$ (35\% probability ellipsoids). Hydrogen atoms are omitted for clarity.

Single-crystals suitable for X-ray structural analysis of $\mathbf{1 3}$ were obtained by crystallization from diethyl ether. The X-ray solid-state structural analysis reveals a mononuclear threecoordinate manganese center with a terminal phenyl group. The sum of the angles at the metal center is $359.9^{\circ}$, which shows that the manganese center has a planar trigonal geometry. The six-membered $\mathrm{MnN}_{2} \mathrm{C}_{3}$ rings are essentially planar, co-planar with the terminal phenyl ring with a mean deviation $\Delta=0.02 \AA$. The dihedral angle between the 
terminal $\mathrm{Ph}$ ring and the $\mathrm{Ph}$ rings of the aryl groups on the nitrogen is $83.9^{\circ}$. The $\mathrm{Mn}-\mathrm{C}$ bond length in $\mathbf{1 3}$ is $2.08 \AA$, which is particularly short compared to those reported for all other terminal $\mathrm{Mn}$-Ph derivatives, ${ }^{50}$ however, in the range of those in $\mathrm{MnR}_{2}\left(\mathrm{R}=\mathrm{C}\left(\mathrm{SiMe}_{3}\right)_{3}{ }^{51 \mathrm{a}}\right.$ and $\left.\mathrm{CH}_{2} \mathrm{CMe}_{3}{ }^{51 \mathrm{~b}}\right)(2.01-2.10 \AA$ ) possessing two-coordinate manganese(II) atoms. The Mn-N bond lengths in $\mathbf{1 3}$ are the shortest among those in compounds $\mathbf{7}$ - $\mathbf{1 3}$ probably due to the low-coordinated metal center consistent with the theoretical calculated results.

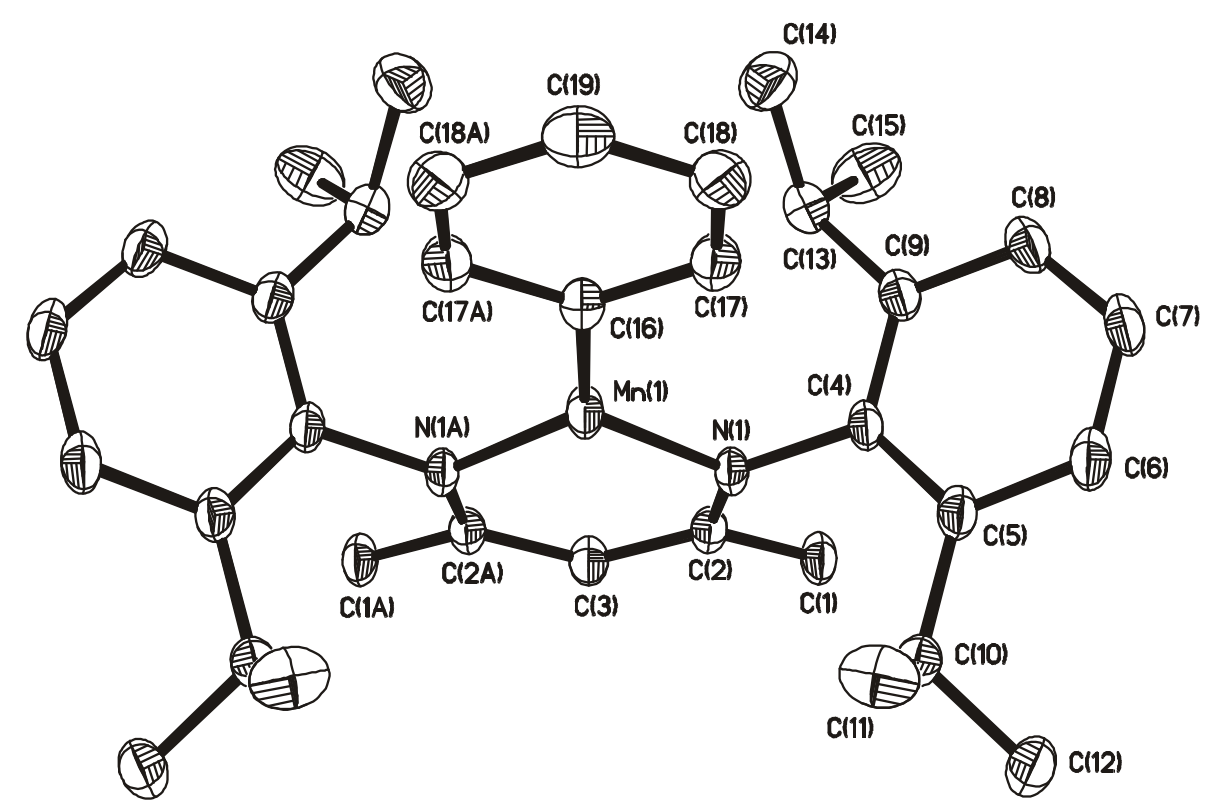

Figure 10. Molecular structure of $\mathbf{1 3}$ (30\% probability ellipsoids). Hydrogen atoms are omitted for clarity.

DFT calculations were carried out to get further insight into the geometry and electronic structure of compound 13. RI-BP86 (TZVP for Mn, SV(P) for the other atoms) with the program Turbomole $5.5^{52}$ was used throughout the calculations except for the localized orbital shown in Figure 11, where B3LYP (6-311G(d) for Mn and 6-31G(d) for the other atoms) in Gaussian $98^{53}$ was used. The reliability of RI-BP86 was tested by comparing the optimized geometry with the experimental structure of compound 13. The maximum deviation of bond length is less than $0.03 \AA$ and of the bond angle is less than $4^{\circ}$. These results show the reliability of the RI-BP86 program compared to the X-ray data of compound 13.

One aim of the theoretical study was to explain the co-planarity of the $\mathrm{Ph}$ ring with the chelating ligand. The result distinctively shows that the two rings in vertical position are less 
stable than in a planar arrangement by $2.9 \mathrm{kcal} / \mathrm{mol}$. However, if the Ar groups on the nitrogen are replaced by $\mathrm{H}$ atoms, the two rings in a vertical position are more stable than a co-planar arrangement by $57.4 \mathrm{kcal} / \mathrm{mol}$, which indicates that the co-planar arrangement of the two rings results from the influence of the Ar groups, not the conjugation between the two rings. The role of the Ar groups can be attributed to two aspects: one is steric repulsion. If the two rings are forced in vertical positions, several short distances between $\mathrm{H}(\mathrm{Ph})$ and $\mathrm{H}(\mathrm{Ar})$ can be found; the other is phenyl-phenyl interaction. In 13 the terminal $\mathrm{Ph}$ and the $\mathrm{Ar}$ groups are nearly in their optimized position for this kind of interaction. ${ }^{54}$

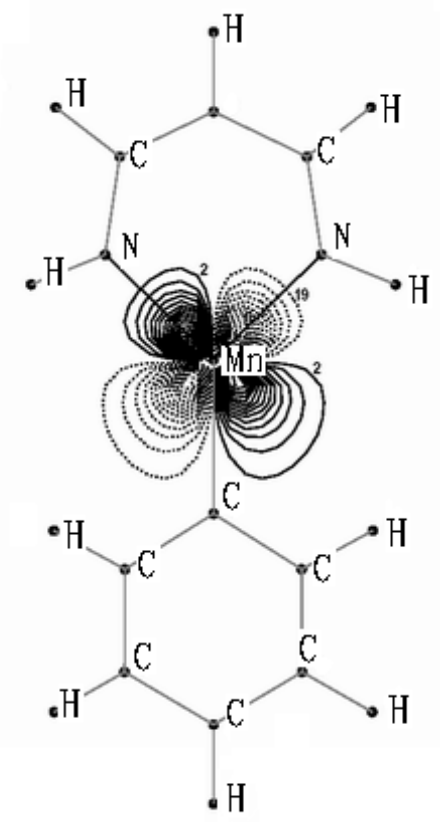

A

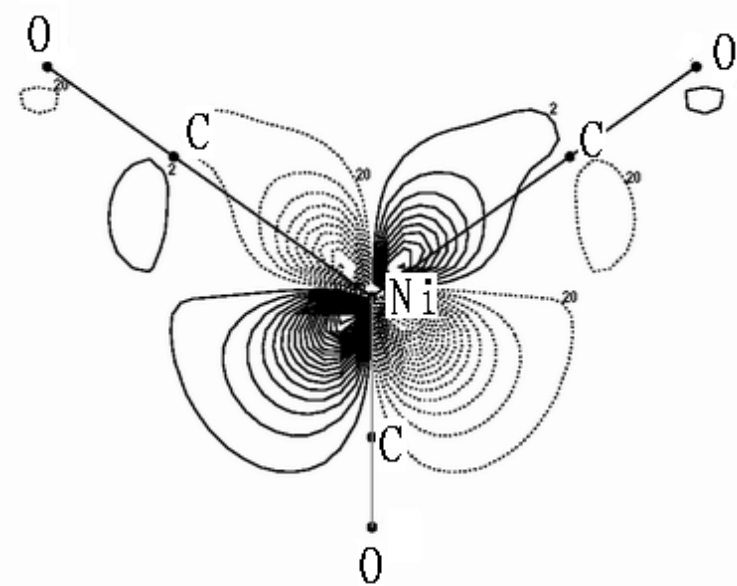

B

Figure 11. The most extended d orbital of the $\mathrm{Mn}$ in $\mathbf{1 3}(\mathrm{A})$ and of the $\mathrm{Ni}$ in $\mathrm{Ni}(\mathrm{CO})_{4}(\mathrm{~B})$.

The calculated results do not support the existence of significant $\mathrm{Mn}-\mathrm{C}$ and $\mathrm{Mn}-\mathrm{N}$ d- $\pi$ conjugation in 13. This is demonstrated by replacment of the terminal $\mathrm{Ph}$ group by $\mathrm{CH}_{3}$, where the Mn-C d- $\pi$ conjugation is impossible, while the Mn-C bond length almost does not change significantly (2.05 - $2.06 \AA)$. Compound 13 was calculated by the B3LYP method (the ligand is replaced by $\mathrm{C}_{3} \mathrm{H}_{5} \mathrm{~N}_{2}$ ) and the molecular orbital was localized by Boys methods, ${ }^{55 a}$ the most extended d orbital of Mn was drawn by MOLDEN 3.8 program ${ }^{55 b}$ (Figure 11). However, when the most extended $\mathrm{Ni} \mathrm{d}$ orbital of $\mathrm{Ni}(\mathrm{CO})_{4}$ is compared with that of $\mathrm{Mn}$ in $\mathbf{1 3}$, the latter $\mathrm{d}$ orbital is well localized around $\mathrm{Mn}$, while in $\mathrm{Ni}(\mathrm{CO})_{4}$ the $\mathrm{d}$ 
orbitals are reformed and overlap with other atoms. These results indicate that the $\mathrm{Mn}-\mathrm{C}$ and $\mathrm{Mn}-\mathrm{N}$ bonds have pure $\sigma$ character and the rather short $\mathrm{Mn}-\mathrm{C}$ and $\mathrm{Mn}-\mathrm{N}$ distances are attributed to the low coordination number of the central metal.

Table 6. Selected bond lengths $(\AA)$ and bond angles $\left({ }^{\circ}\right)$ for compounds $\mathbf{1 2}$ and $\mathbf{1 3}$

\begin{tabular}{lccr}
\hline \multicolumn{4}{c}{ Compound 12 } \\
\hline $\mathrm{Mn}(1)-\mathrm{N}(1)$ & $2.125(2)$ & $\mathrm{N}(1)-\mathrm{Mn}(1)-\mathrm{N}(2)$ & $89.68(6)$ \\
$\mathrm{Mn}(1)-\mathrm{N}(2)$ & $2.129(2)$ & $\mathrm{N}(1)-\mathrm{Mn}(1)-\mathrm{C}(30)$ & $117.53(8)$ \\
$\mathrm{Mn}(1)-\mathrm{C}(30)$ & $2.241(2)$ & $\mathrm{N}(2)-\mathrm{Mn}(1)-\mathrm{C}(30)$ & $117.18(8)$ \\
$\mathrm{Mn}(1)-\mathrm{C}(30 \mathrm{~A})$ & $2.306(2)$ & $\mathrm{N}(1)-\mathrm{Mn}(1)-\mathrm{C}(30 \mathrm{~A})$ & $114.41(7)$ \\
$\mathrm{Mn}(1)-\mathrm{Mn}(1 \mathrm{~A})$ & $2.809(1)$ & $\mathrm{N}(2)-\mathrm{Mn}(1)-\mathrm{C}(30 \mathrm{~A})$ & $114.72(8)$ \\
\hline & & $\mathrm{N}(1)-\mathrm{Mn}(1)-\mathrm{N}(1 \mathrm{~A})$ & $91.31(16)$ \\
$\mathrm{Mn}(1)-\mathrm{N}(1)$ & $2.041(3)$ & $\mathrm{N}(1)-\mathrm{Mn}(1)-\mathrm{C}(16)$ & $134.27(8)$ \\
$\mathrm{Mn}(1)-\mathrm{N}(1 \mathrm{~A})$ & $2.041(3)$ & $\mathrm{N}(1 \mathrm{~A})-\mathrm{Mn}(1)-\mathrm{C}(16)$ & $134.28(8)$ \\
$\mathrm{Mn}(1)-\mathrm{C}(16)$ & $2.077(6)$ & &
\end{tabular}

\subsubsection{Reactivity of Compound 9 and Formation of Compounds $\mathrm{LMnC}_{3} \mathrm{H}_{5}$ (THF) (14) and $[\mathrm{LMn}(\mu-\mathrm{CCPh})]_{2}(15)$}

Addition of $\mathrm{C}_{3} \mathrm{H}_{5} \mathrm{MgCl}$ and PhCCLi to 9 in toluene, respectively, at low temperature smoothly provided the monomeric compound $\mathrm{LMnC}_{3} \mathrm{H}_{5}(\mathrm{THF})$ (14) and the dimeric compound $[\mathrm{LMn}(\mu-\mathrm{CCPh})]_{2}$ (15) in moderate yields (Scheme 8). The efforts to identify other species were unsuccessful. Compared to the substitution reactions of the dimer $\mathbf{8}$ with MeLi and $\mathrm{PhLi}$, the reactions of 9 with $\mathrm{C}_{3} \mathrm{H}_{5} \mathrm{MgCl}$ and PhCCLi resulted in easily accessible products 14 and 15, which can be purified by recrystallization from hexane.

Complexes 14 and $\mathbf{1 5}$ are yellow crystalline solids soluble in THF. They are highly sensitive to air and moisture. In the EI-MS of 14, $\left[\mathrm{LMnC}_{3} \mathrm{H}_{5}\right]^{+}$is observed at $\mathrm{m} / \mathrm{z}, 537(8 \%)$ without the coordinated THF, followed by $\mathrm{m} / z 472[\mathrm{LMn}]^{+}$as the most intense peak. Interestingly, the molecular ion $\mathrm{M}^{+}$at $\mathrm{m} / z, 1146$ in the mass spectrum of $\mathbf{1 5}$ can be seen albeit with very low intensity (1\%), followed by $[1 / 2 \mathrm{M}]^{+} \mathrm{m} / \mathrm{z} 573(40 \%)$ and $[\mathrm{LMn}-\mathrm{H}]^{+} \mathrm{m} / \mathrm{z} 471$ (100\%). The vibration for the bridging $-\mathrm{C} \equiv \mathrm{C}$ - group in the IR spectrum of $\mathbf{1 5}$ appears at $2034 \mathrm{~cm}^{-1}$, which is consistent with the decrease of the bond strength of the $\mathrm{C} \equiv \mathrm{C}$ unit due to the $\pi$-interaction with the metal center. ${ }^{56}$ 


\section{Scheme 8}

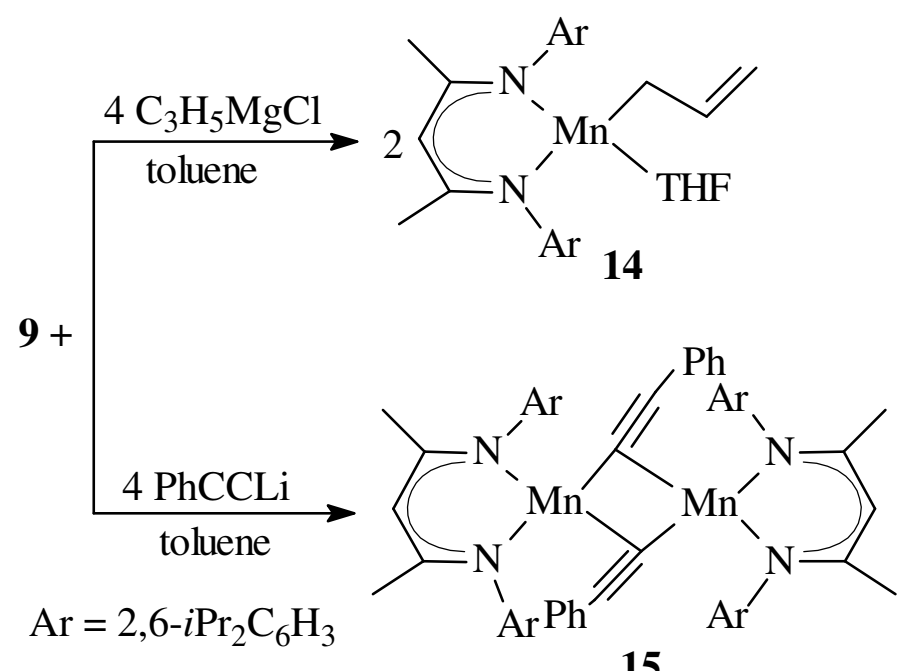

15

Complexes 14 and 15 were characterized by single-crystal X-ray diffraction. The structures are shown in Figures 12 and 13, respectively. Selected bond lengths and angles are given in Table 7.

Compound $\mathbf{1 4}$ is a monomric species with the allyl ligand bound to the four-coordinate manganese center in an $\eta^{1}$ arrangement. To the best of our knowledge, 2 is the first structurally characterized allyl-manganese complex with $\eta^{1}$ bonding of the ligand. The metal center is of distorted tetrahedral geometry surrounded by the allyl group, a THF molecule and the chelating ligand. The backbone of the chelating ligand is nearly planar with the manganese atom out of this plane $(0.53 \AA)$, which is nearly in orthogonal position with the plane formed by $\mathrm{Mn}(1), \mathrm{C}(6)$ and $\mathrm{O}(1)$. The Mn-C bond length $(2.13 \AA)$ is in the range of Mn-C single bonds and a little shorter than those in manganese complexes with allyl groups in an $\eta^{3}$ mode. ${ }^{57}$ The large difference between the distances of $\mathrm{C}(7)-\mathrm{C}(8)(1.31 \AA)$ and $\mathrm{C}(6)$ $\mathrm{C}$ (7) (1.44 $\AA$ ) shows there is no significant delocalization of $\pi$-electrons in the allyl group. The distance between $\mathrm{Mn}(1)$ and $\mathrm{C}(8)$ (3.88 ̊) do not support any bonding interaction. Interestingly, both the N-Mn-N angle (92.2 $)$ and the Mn-N bond lengths (av. $2.09 \AA$ ) in 14 are larger than the corresponding ones in $9\left(91.3^{\circ}\right.$ and $2.08 \AA$, respectively) due to the different trans effect.

The solid-state structure of $\mathbf{1 5}$ reveals a dimer formed by two bridging phenylethynyl groups, which is best described by assuming that $\mathrm{Mn}(1)-\mathrm{C}(30)$ is a $\sigma$-bond, and that the two monomer units are linked together through $\pi$-bonding by donation of $\pi$-electron density of one $\mathrm{C} \equiv \mathrm{C}$ bond to the empty orbital of the other metal center. To the best of our knowledge, 
compound $\mathbf{1 5}$ is the first structurally characterized dinuclear manganese complex containing bridging alkynyl groups. Similar to complexes 9 and 14, the manganese atom is out of the chelating ligand plane $(0.47 \AA)$. The central core contains an ideal planar four-membered $\mathrm{Mn}_{2} \mathrm{C}_{2}$ ring, which bisects and is perpendicular $\left(90.8^{\circ}\right)$ to the two chelating ligands around it. The distance between the two manganese atoms (3.12 $\AA$ ) is beyond a Mn-Mn bonding range and significantly longer than those in dimeric manganese alkyl complexes $[\operatorname{LMn}(\mu-\mathrm{Me})]_{2}$ (12) $(2.81 \AA)$ and $\mathrm{Mn}_{2}\left(\mathrm{CH}_{2} \mathrm{SiMe}_{3}\right)_{4}\left(\mathrm{PMe}_{3}\right)_{2}{ }^{48}(2.77 \AA)$. This indicates that the bridge bonding in $\mathbf{1 5}$ is different from those in other dimeric species. ${ }^{48}$ The carbon-carbon triple bond length $(1.23 \AA)$ is longer than the accepted average value of $1.21 \AA{ }^{58}$ reflecting the $\pi$ interaction between the triple bond and the metal center. Similar bond lengths are observed in $\left[\mathrm{CuCl}\left(\eta^{2}-\mathrm{PhCCMn}(\mathrm{CO})_{3}(\mathrm{dppe})\right)\right]^{59 \mathrm{a}}(1.23 \AA)$ and $\left\{\mathrm{Cu}\left[\eta^{2}-t \mathrm{BuCCMn}(\mathrm{CO})_{3}(\mathrm{dppe})\right]_{2}\right\} \mathrm{PF}_{6}^{59 b}$ $(1.24 \AA)$ having alkynyl-manganese groups $\pi$-bonded to the copper. Despite the $\pi$ interaction between the triple bond and the metal center in $\mathbf{1 5}$, the $\mathrm{Mn}(1 \mathrm{~A})-\mathrm{C}(30)-\mathrm{C}(31)$ unit remains almost linear $\left(177.0^{\circ}\right)$. The Mn-C bond lengths (av. $2.22 \AA$ ) are significantly longer than those (1.90 - 2.08 $\AA$ ) in manganese complexes with terminal alkynyl groups. ${ }^{16 a}$

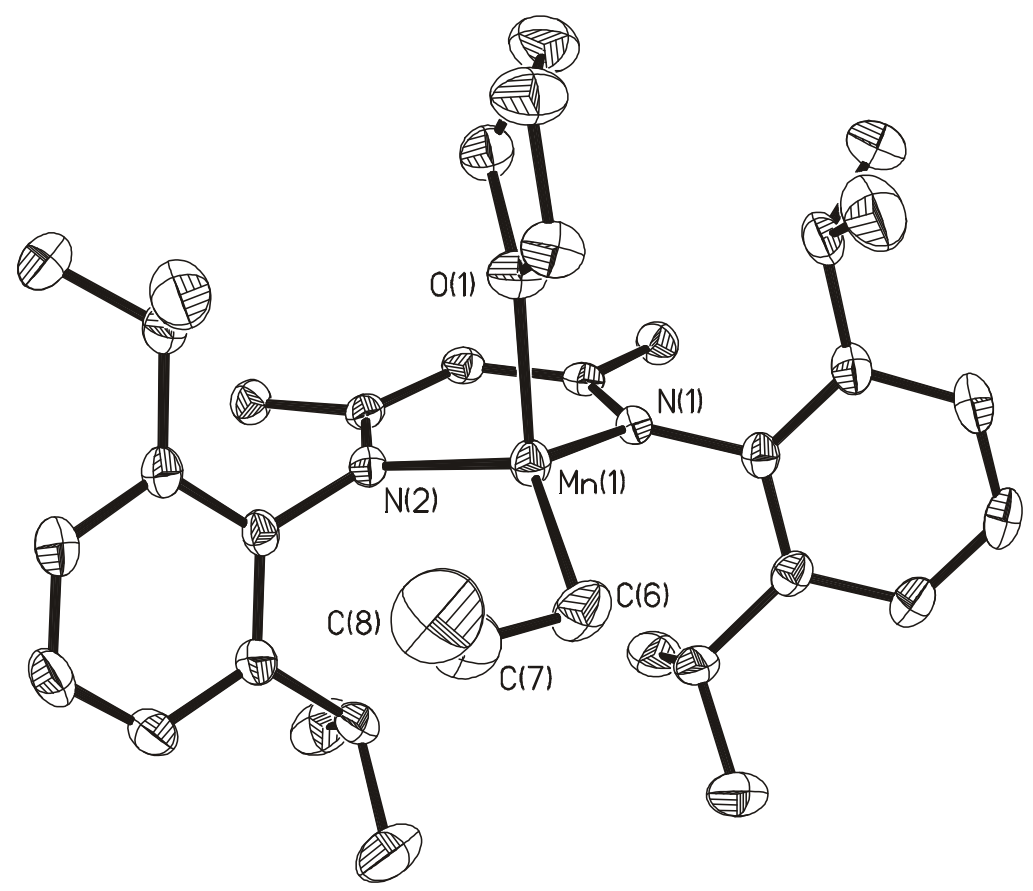

Figure 12. Molecular structure of $\mathbf{1 4}$ (50\% probability ellipsoids). Hydrogen atoms are omitted for clarity. 


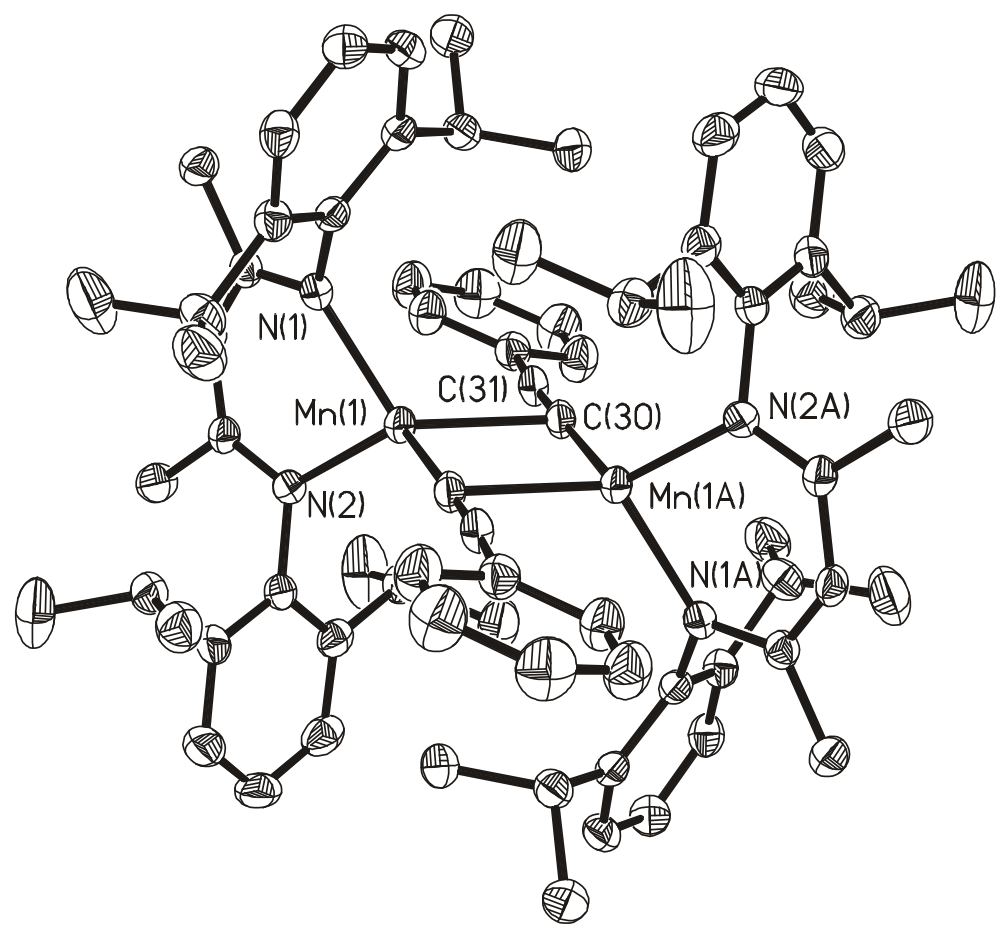

Figure 13. Molecular structure of $\mathbf{1 5}$ (50\% probability ellipsoids). Hydrogen atoms are omitted for clarity.

Table 7. Selected bond lengths $(\AA)$ and bond angles $\left({ }^{\circ}\right)$ for compounds $\mathbf{1 4}$ and $\mathbf{1 5}$

\begin{tabular}{lllr}
\hline \multicolumn{4}{c}{ Compound 14 } \\
\hline $\mathrm{Mn}(1)-\mathrm{N}(1)$ & $2.0915(16)$ & $\mathrm{N}(1)-\mathrm{Mn}(1)-\mathrm{N}(2)$ & $92.19(6)$ \\
$\mathrm{Mn}(1)-\mathrm{N}(2)$ & $2.0948(15)$ & $\mathrm{N}(1)-\mathrm{Mn}(1)-\mathrm{C}(6)$ & $123.58(7)$ \\
$\mathrm{Mn}(1)-\mathrm{C}(6)$ & $2.132(2)$ & $\mathrm{N}(2)-\mathrm{Mn}(1)-\mathrm{C}(6)$ & $123.35(8)$ \\
$\mathrm{Mn}(1)-\mathrm{O}(1)$ & $2.1632(14)$ & $\mathrm{N}(1)-\mathrm{Mn}(1)-\mathrm{O}(1)$ & $102.62(6)$ \\
$\mathrm{C}(7)-\mathrm{C}(8)$ & $1.305(4)$ & $\mathrm{N}(2)-\mathrm{Mn}(1)-\mathrm{O}(1)$ & $101.77(6)$ \\
$\mathrm{C}(6)-\mathrm{C}(7)$ & $1.444(3)$ & $\mathrm{C}(6)-\mathrm{Mn}(1)-\mathrm{O}(1)$ & $109.60(8)$ \\
\hline & & $\mathrm{N}(1)-\mathrm{Mn}(1)-\mathrm{N}(2)$ & \\
\hline $\mathrm{Mn}(1)-\mathrm{N}(1)$ & $2.0907(18)$ & $\mathrm{N}(1)-\mathrm{Mn}(1)-\mathrm{C}(30)$ & $119.51(8)$ \\
$\mathrm{Mn}(1)-\mathrm{N}(2)$ & $2.1045(18)$ & $\mathrm{N}(2)-\mathrm{Mn}(1)-\mathrm{C}(30)$ & $120.78(7)$ \\
$\mathrm{Mn}(1)-\mathrm{C}(30)$ & $2.298(2)$ & $\mathrm{C}(30)-\mathrm{Mn}(1)-\mathrm{C}(30 \mathrm{~A})$ & $90.55(8)$ \\
$\mathrm{Mn}(1)-\mathrm{C}(30 \mathrm{~A})$ & $2.133(2)$ & $\mathrm{N}(1)-\mathrm{Mn}(1)-\mathrm{C}(30 \mathrm{~A})$ & $116.68(8)$ \\
$\mathrm{Mn}(1 \mathrm{~A})-\mathrm{C}(30)$ & $2.133(2)$ & $\mathrm{N}(2)-\mathrm{Mn}(1)-\mathrm{C}(30 \mathrm{~A})$ & $122.72(8)$ \\
$\mathrm{Mn}(1)-\mathrm{Mn}(1 \mathrm{~A})$ & $3.1202(7)$ & $\mathrm{Mn}(1 \mathrm{~A})-\mathrm{C}(30)-\mathrm{C}(31)$ & $177.17(19)$ \\
$\mathrm{C}(30)-\mathrm{C}(31)$ & $1.226(3)$ &
\end{tabular}




\subsection{Synthesis and Structure of the Dinuclear Manganese Acetate 16}

\subsubsection{Synthesis and Spectroscopic Characterization of $[\mathrm{LMn}(\mu-\mathrm{MeCOO})]_{2}(16)$}

Dinuclear manganese complexes bridged by carboxylate groups have attracted great attention since such systems are known to exist at the active centers of some manganesecontaining enzymes. ${ }^{60}$ It was of interest to model the structures and functions of the manganese centers in such enzymes. The doubly carboxylate-bridged complex $[\operatorname{LMn}(\mu-$ $\mathrm{MeCOO})]_{2}$ (16) was prepared from 6 and $\mathrm{Mn}(\mathrm{MeCOO})_{2}$ in THF in good yield (Scheme 9). However, compound $\mathbf{1 6}$ could not be obtained when $\mathbf{5}$ was used instead of $\mathbf{6}$.

\section{Scheme 9}

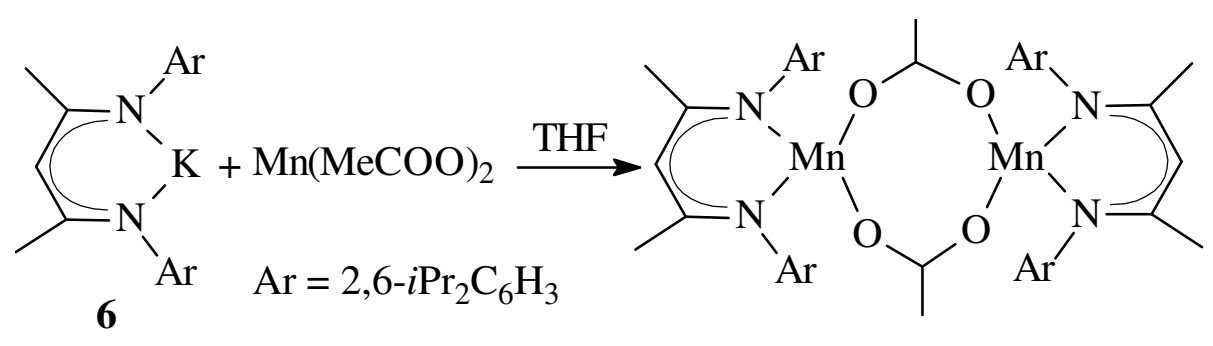

The molecular ion peak of the dimeric complex $\mathbf{1 6}$ in the mass spectrum is not observed, whereas half of the molecular mass $[1 / 2 \mathrm{M}]^{+}$is found at $\mathrm{m} / \mathrm{z} 531$ as the most intense peak. The IR spectrum of $\mathbf{1 6}$ displays the prominent vibrations for the O-C-O part of the bridging acetate groups $v_{a s}\left(1602 \mathrm{~cm}^{-1}\right)$ and $v_{s}\left(1437 \mathrm{~cm}^{-1}\right)$.

\subsubsection{X-ray Solid-state Structural Analysis of Complex 16}

Compound 16 crystallizes in the monoclinic space group $P 2_{1} / n$ with four molecules per unit cell. The structure of $\mathbf{1 6}$ is shown in Figure 14. The central manganese atoms are bonded to two nitrogen atoms each from the chelating ligands and two oxygen atoms from the two bridging acetates in a distorted tetrahedral fashion. To the best of our knowledge, compound $\mathbf{1 6}$ is the first example of a doubly carboxylate-bridged complex with fourcoordinate manganese(II). Similar to complexes 7 - 15, the manganese atoms in $\mathbf{1 6}$ are out of the chelating ligand planes (av. $0.64 \AA$ ). Complex 16 contains two peripheral six-membered $\mathrm{C}_{3} \mathrm{~N}_{2} \mathrm{Mn}$ rings and one central eight-membered $\mathrm{C}_{2} \mathrm{Mn}_{2} \mathrm{O}_{4}$ macrocycle. The six- and eightmembered rings are nearly orthogonal to each other as shown by a dihedral angle of $85.8^{\circ}$. 
The two acetates are in the bidentate $\mu_{1,3}$ syn-syn bridging mode, which is rare in the doubly carboxylate-bridged manganese(II) complexes. ${ }^{60}$ The Mn-O distances (av. $2.01 \AA$ ) for the acetate bridges in 16 compare well with those $(2.00-2.24 \AA)$ observed in the manganese complexes adopting the same $\mu_{1,3}$ mode. ${ }^{24}$ The non-bonding Mn-Mn distance (4.32 $\AA$ ) is in the range $(4.15-4.79 \AA)$ of those found in comparable manganese(II) complexes. $^{60}$

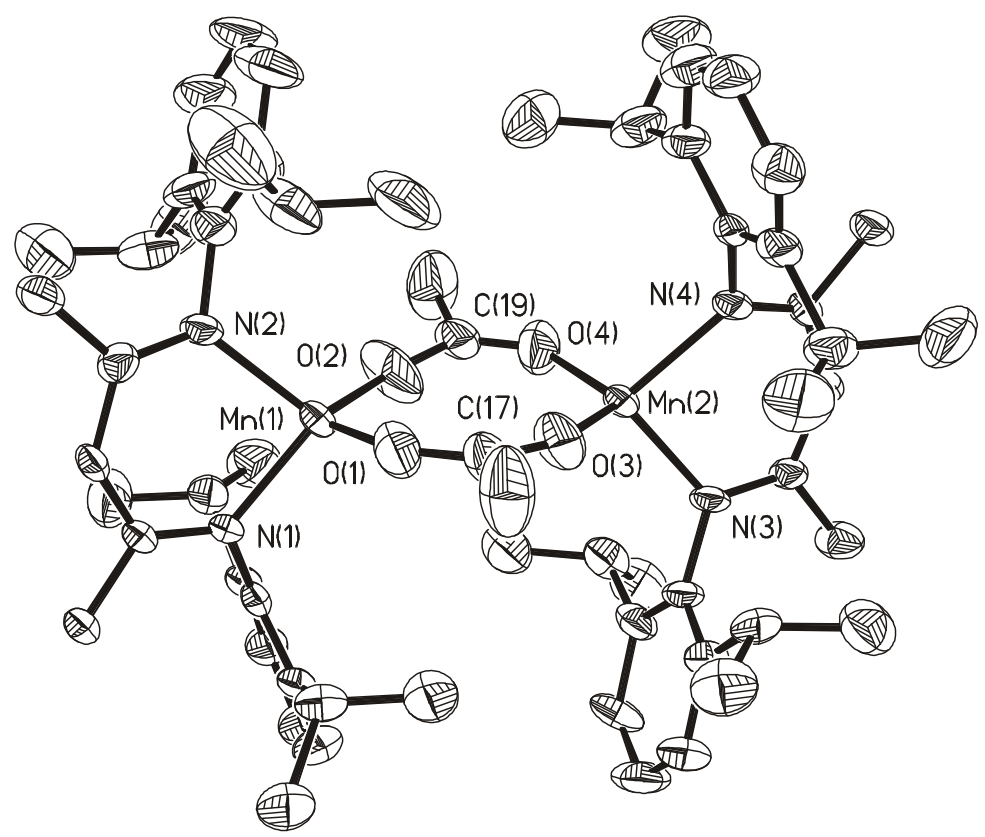

Figure 14. Molecular structure of $\mathbf{1 6}$ (50\% probability ellipsoids). Hydrogen atoms are omitted for clarity.

Table 8. Selected bond lengths $(\AA)$ and bond angles $\left({ }^{\circ}\right)$ for compound 16

\begin{tabular}{llll}
\hline $\mathrm{Mn}(1)-\mathrm{N}(1)$ & $2.075(6)$ & $\mathrm{N}(1)-\mathrm{Mn}(1)-\mathrm{N}(2)$ & $90.9(2)$ \\
$\mathrm{Mn}(1)-\mathrm{N}(2)$ & $2.077(6)$ & $\mathrm{N}(1)-\mathrm{Mn}(1)-\mathrm{O}(1)$ & $110.9(3)$ \\
$\mathrm{Mn}(1)-\mathrm{O}(1)$ & $2.014(7)$ & $\mathrm{N}(1)-\mathrm{Mn}(1)-\mathrm{O}(2)$ & $115.6(3)$ \\
$\mathrm{Mn}(1)-\mathrm{O}(2)$ & $1.991(7)$ & $\mathrm{N}(2)-\mathrm{Mn}(1)-\mathrm{O}(1)$ & $110.9(3)$ \\
$\mathrm{Mn}(2)-\mathrm{N}(3)$ & $2.082(6)$ & $\mathrm{N}(2)-\mathrm{Mn}(1)-\mathrm{O}(2)$ & $112.3(3)$ \\
$\mathrm{Mn}(2)-\mathrm{N}(4)$ & $2.086(6)$ & $\mathrm{O}(1)-\mathrm{Mn}(1)-\mathrm{O}(2)$ & $114.1(3)$ \\
$\mathrm{Mn}(2)-\mathrm{O}(3)$ & $2.012(7)$ & $\mathrm{O}(3)-\mathrm{Mn}(2)-\mathrm{O}(4)$ & $117.8(3)$ \\
$\mathrm{Mn}(2)-\mathrm{O}(4)$ & $2.031(7)$ & $\mathrm{N}(3)-\mathrm{Mn}(2)-\mathrm{N}(4)$ & $92.0(2)$ \\
$\mathrm{Mn}(1)-\mathrm{Mn}(2)$ & $4.319(7)$ & & \\
\hline
\end{tabular}




\subsection{Synthesis, Structure and Reactivity of Manganese Iodides 17 - 19 Containing the Bulky $\beta$-Diketiminate Ligand}

Organometallic iodide complexes have unique chemical properties due to the labile M-I bond compared to their $\mathrm{M}-\mathrm{Cl}$ congeners. ${ }^{61}$ Recent results in our group proved that aluminum iodide $\mathrm{LAlI}_{2}$ bearing the $\beta$-diketiminate ligand is a good starting material for some interesting reactions such as reduction and hydrolysis. For instance, we reported the monomeric $\mathrm{LAl}$ as a stable carbene analogue by reduction of $\mathrm{LAlI}_{2}$ with potassium. ${ }^{36}$ Furthermore, the aluminum dihydroxide $\mathrm{LAl}(\mathrm{OH})_{2}$ with terminal $\mathrm{OH}$ groups was obtained by hydrolysis of $\mathrm{LAlI}_{2}$ using a liquid $\mathrm{NH}_{3}$ /toluene two-phase system. ${ }^{37}$ Consequently we became interested in transition metals and investigated the behavior of $\mathrm{Mn}$ iodides bearing $\beta$-diketiminate ligands. However, the efforts to reduce $\operatorname{LMn}(\mu-\mathrm{I})_{2} \operatorname{Li}\left(\mathrm{OEt}_{2}\right)_{2}$ were unsuccessful with sodium or potassium, maybe due to the stability of the lithium salt. ${ }^{40 a}$ Therefore it was of interest to synthesize manganese iodides free of lithium salt and explore their reactivity.

\subsubsection{Synthesis and Spectroscopic Characterization of Complexes 17 - 19}

The reaction of $\mathrm{MnI}_{2}$ with one equiv. of $\mathrm{LLi}\left(\mathrm{OEt}_{2}\right)$ (5) in diethyl ether afforded the heterobimetallic complex $\operatorname{LMn}(\mu-\mathrm{I})_{2} \mathrm{Li}\left(\mathrm{OEt}_{2}\right)_{2} \cdot{ }^{40 \mathrm{a}}$ Attempts to remove the coordinated lithium salt from the manganese center were unsuccessful. However, the reaction of $\mathrm{MnI}_{2}$ with one equiv. of LK (6) in THF easily gave the monomeric compound LMnI(THF) (17) in high yield (87\%) with a coordinated THF at the metal center. The EI-MS of 17 exhibits $[\mathrm{LMnI}]^{+}(\mathrm{m} / z$ 599) as the most intense peak without the coordinated THF. The formula of 17 was confirmed by the crystal structure (Figure 15). Attempts to prepare the di- $\beta$-diketiminate complex by using 2 equiv. of 5 or $\mathbf{6}$ were unsuccessful.

\section{Scheme 10}

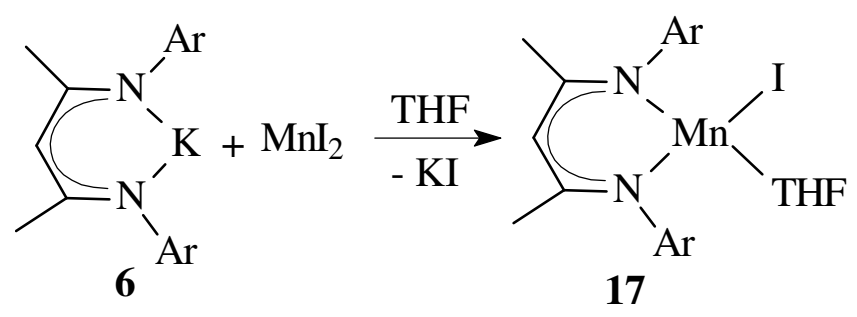


Refluxing 17 in toluene for $0.5 \mathrm{~h}$ and removing all the volatiles in vacuum afforded the dimeric compound $\left[\mathrm{LMn}(\mu \text {-I) }]_{2}\right.$ (18). Crystals suitable for X-ray analysis were obtained by recrystallization from toluene. The EI-MS of $\mathbf{1 8}$ does not exhibit the molecular ion peak $\mathrm{M}^{+}$ whereas half of the molecular mass $[\mathrm{LMnI}]^{+}$is observed at $\mathrm{m} / z 599(100 \%)$, which shows that $\mathbf{1 8}$ is monomeric in the gas phase and no indication of fragments containing $\mathrm{Mn}-\mathrm{Mn}$ species, which is consistent with the X-ray solid-state structural analysis. Compound $\mathbf{1 7}$ can also be obtained by dissolving 18 in THF (Scheme 11).

\section{Scheme 11}

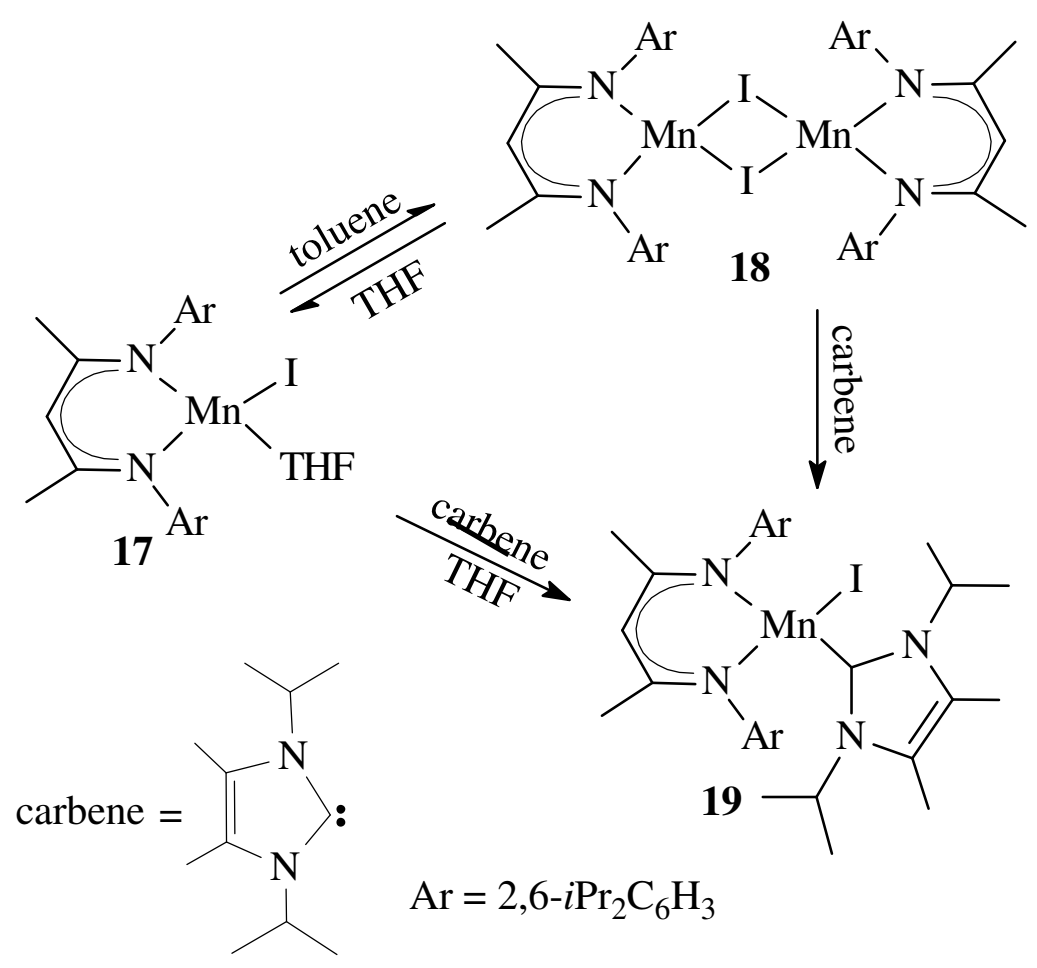

Compound $\mathbf{1 7}$ can be considered as an adduct of a Lewis acid LMnI and a weak Lewis base THF. On the one hand, displacement the THF by a strong Lewis base $\mathrm{C}[\mathrm{N}(i \mathrm{Pr}) \mathrm{C}(\mathrm{Me})]_{2}$ (1) readily afforded the carbene adduct $\operatorname{LMnI}\left\{\mathrm{C}[\mathrm{N}(i \mathrm{Pr}) \mathrm{C}(\mathrm{Me})]_{2}\right\}$ (19), which can also be obtained by adding $\mathbf{1}$ to the solution of $\mathbf{1 8}$ in toluene. On the other hand we were not able to prepare 18 by removing the carbene in $\mathbf{1 9}$, which shows that the $\mathrm{N}$-heterocyclic carbene is a much stronger $\sigma$-donor ligand. Compounds 17-19 are all soluble in polar solvents such as THF and toluene and have a poor solubility in hydrocarbon solvents. 


\subsubsection{X-ray Solid-state Structural Analyses of Complexes 17 and 18}

The X-ray solid-state structural analyses reveal that LMnI(THF) (17) is monomeric and $[\operatorname{LMn}(\mu-\mathrm{I})]_{2}(\mathbf{1 8})$ dimeric in the solid state (Figures 15 and 16). In both compounds the manganese centers are four-coordinate and display a distorted tetrahedral geometry. The backbone of the chelating ligand is nearly planar and the manganese atom is in both compounds out of the $\mathrm{C}_{3} \mathrm{~N}_{2}$ plane $(0.62 \AA$ in $\mathbf{1 7}$ and $0.43 \AA$ in 18).

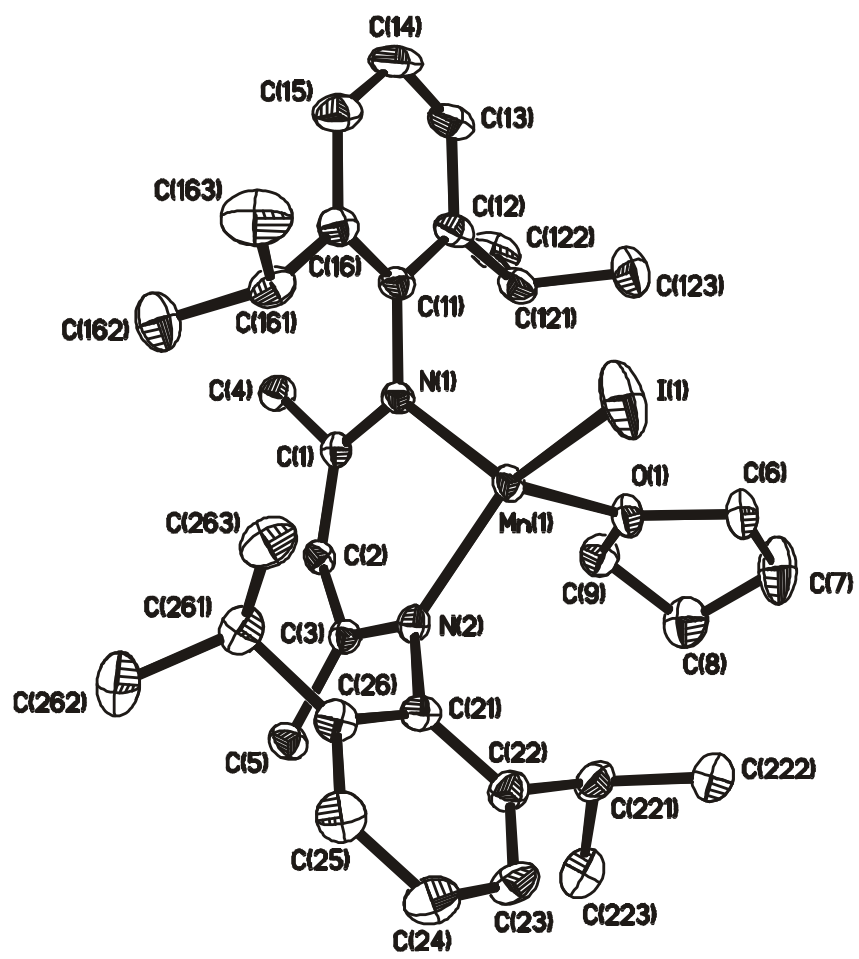

Figure 15. Molecular structure of $\mathbf{1 7}$ (30\% probability ellipsoids). Hydrogen atoms are omitted for clarity.

The terminal Mn-I distance (2.63 $\AA$ ) in $\mathbf{1 7}$ is comparable to the reported values for terminal Mn-I bonds such as those in $(\text { sima })_{2} \mathrm{MnI}^{62}(2.62 \AA)\left(\right.$ sima $\left.=\mathrm{NSiMe}_{3} \mathrm{CPhNSiMe}_{3}\right)$ and $\mathrm{MnI}_{2}\left(\mathrm{PEt}_{3}\right)_{2}{ }^{26}$ (av. 2.67) $\AA$ ), significantly shorter than the bridging Mn-I bonds in 18 (2.77 and $2.75 \AA$ ) and $\operatorname{LMn}(\mu-\mathrm{I})_{2} \operatorname{Li}\left(\mathrm{OEt}_{2}\right)_{2}{ }^{40 \mathrm{a}}(2.72$ and $2.73 \AA)$. The two manganese atoms are bridged by two iodine atoms in $\mathbf{1 8}$ and the distance between them is $3.62 \AA$, which is out of the range of a Mn-Mn bond. The $\mathrm{Mn}_{2} \mathrm{I}_{2}$ four-membered ring is exactly planar, bisecting and perpendicular to the two chelating ligands around it. 


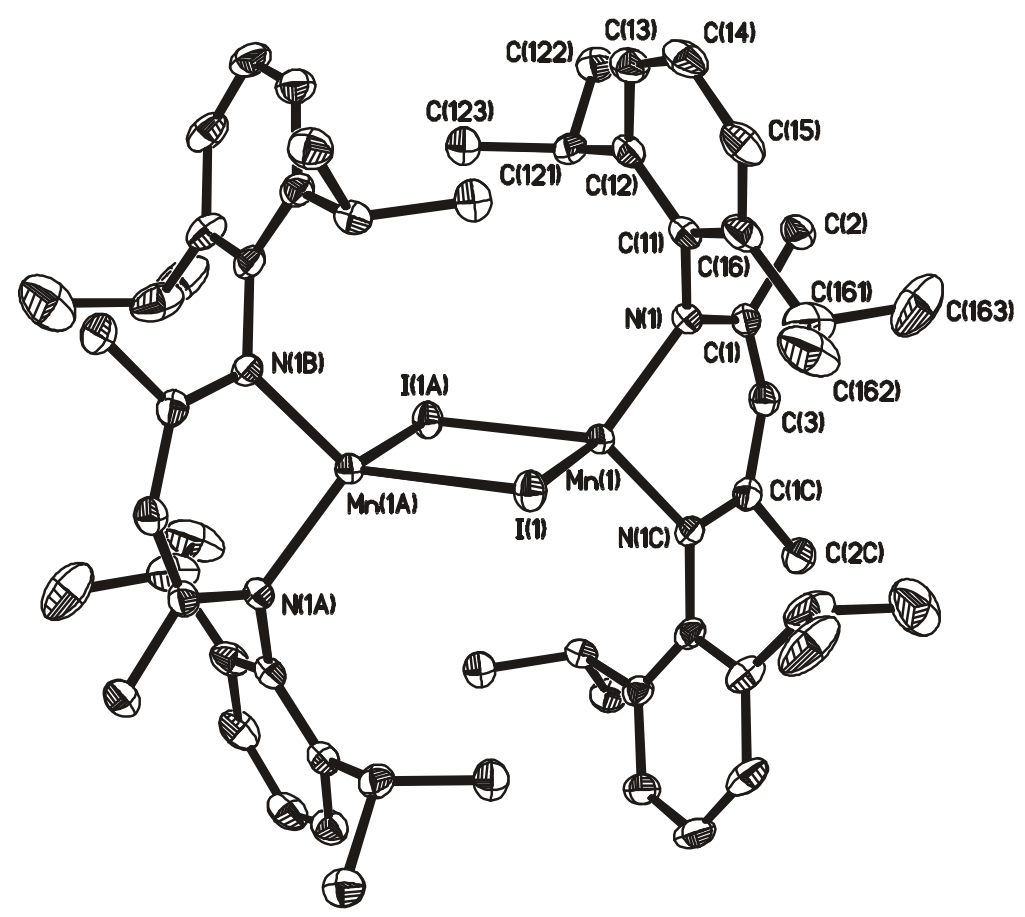

Figure 16. Molecular structure of $\mathbf{1 8}$ (30\% probability ellipsoids). Hydrogen atoms are omitted for clarity.

Table 9. Selected bond lengths $(\AA)$ and bond angles $\left(^{\circ}\right)$ for compounds $\mathbf{1 7}$ and $\mathbf{1 8}$

\begin{tabular}{llcr}
\hline \multicolumn{5}{c}{ Compound 17 } \\
\hline $\mathrm{Mn}(1)-\mathrm{N}(1)$ & $2.079(3)$ & $\mathrm{N}(2)-\mathrm{Mn}(1)-\mathrm{O}(1)$ & $104.28(12)$ \\
$\mathrm{Mn}(1)-\mathrm{N}(2)$ & $2.070(3)$ & $\mathrm{N}(1)-\mathrm{Mn}(1)-\mathrm{O}(1)$ & $101.90(1)$ \\
$\mathrm{Mn}(1)-\mathrm{O}(1)$ & $2.155(3)$ & $\mathrm{N}(2)-\mathrm{Mn}(1)-\mathrm{I}(1)$ & $124.79(9)$ \\
$\mathrm{Mn}(1)-\mathrm{I}(1)$ & $2.6272(8)$ & $\mathrm{N}(1)-\mathrm{Mn}(1)-\mathrm{I}(1)$ & $124.12(9)$ \\
$\mathrm{N}(2)-\mathrm{Mn}(1)-\mathrm{N}(1)$ & $93.56(13)$ & $\mathrm{I}(1)-\mathrm{Mn}(1)-\mathrm{O}(1)$ & $104.96(8)$ \\
\hline & & $\mathrm{N}(1)-\mathrm{Mn}(1)-\mathrm{I}(1)$ & $119.04(7)$ \\
$\mathrm{Mn}(1)-\mathrm{N}(1)$ & $2.067(2)$ & $\mathrm{N}(1 \mathrm{C})-\mathrm{Mn}(1)-\mathrm{I}(1)$ & $119.04(7)$ \\
$\mathrm{Mn}(1)-\mathrm{N}(1 \mathrm{C})$ & $2.067(2)$ & $\mathrm{N}(1)-\mathrm{Mn}(1)-\mathrm{I}(1 \mathrm{~A})$ & $113.02(7)$ \\
$\mathrm{Mn}(1)-\mathrm{I}(1)$ & $2.7484(8)$ & $\mathrm{I}(1)-\mathrm{Mn}(1)-\mathrm{I}(1 \mathrm{~A})$ & $98.14(2)$ \\
$\mathrm{Mn}(1)-\mathrm{I}(1 \mathrm{~A})$ & $2.7688(7)$ & $\mathrm{Mn}(1)-\mathrm{I}(1)-\mathrm{Mn}(1 \mathrm{~A})$ & $81.86(2)$ \\
$\mathrm{Mn}(1 \mathrm{~A})-\mathrm{I}(1)$ & $2.7688(7)$ & & \\
$\mathrm{N}(1)-\mathrm{Mn}(1)-\mathrm{N}(1 \mathrm{C})$ & $95.57(14)$ & & \\
\hline
\end{tabular}




\subsubsection{Reactivity of Compound 19 and the Derivative LMnNHAr $\left\{\mathrm{C}[\mathrm{N}(i \mathrm{Pr}) \mathrm{C}(\mathrm{Me})]_{2}\right\}(\mathbf{2 0})$}

Reduction of 19 by $\mathrm{Na} / \mathrm{K}$ alloy at room temperature unexpectedly resulted in the formation of the monomeric compound $\mathbf{2 0}$ in low yield. Efforts to identify other species were unsuccessful. Assuming that $\mathrm{Mn}$ (II) complexes are used as radical initiators for radical polymerization processes, ${ }^{63}$ it was tempting to propose that the formation of compound $\mathbf{2 0}$ is due to the partially decomposition of the intermediate radical $\left[\mathrm{LMnC}\{\mathrm{N}(i \operatorname{Pr}) \mathrm{C}(\mathrm{Me})\}_{2}\right]^{\bullet}$, which can not aggregate due to the presence of the bulky N-heterocyclic carbene. In the mass spectrum [LMnNHAr] ${ }^{+}$was observed at $\mathrm{m} / \mathrm{z}, 648(52 \%)$, followed by $[\mathrm{LMn}]^{+}(472$, $100 \%$ ). The elemental analyses are consistent with the solid-state structure. Compound 20 can also be prepared in good yield (76\%) by the reaction of 19 with LiNHAr (Scheme 12).

\section{Scheme 12}

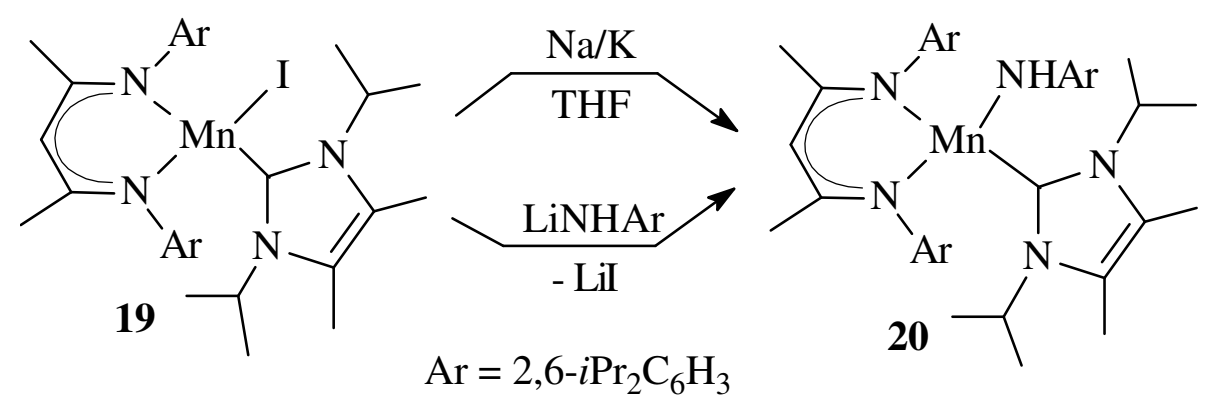

Compound 20 crystallizes in the monoclinic space group $P 2_{1} / c$ with four molecules per unit cell. The structure of $\mathbf{2 0}$ is shown in Figure 17. The central manganese atom is bonded to three nitrogen atoms and one carbene carbon in a distorted tetrahedral fashion. The Mn-C distance $(2.27 \AA)$ in $\mathbf{2 0}$ is in the normal range of those in the manganates $[\mathrm{Li}(\mathrm{TMEDA})]_{2}\left[\mathrm{MnR}_{4}\right]^{64}(2.22-2.28 \AA)\left(\mathrm{R}=\mathrm{Me}, \mathrm{Et}, \mathrm{Bu}\right.$ and $\left.\mathrm{CH}_{2} \mathrm{SiMe}_{3}\right)$. However it is significantly longer than the $\mathrm{Mn}-\mathrm{C}$ (carbene) distance in extensively studied manganese carbonyl carbene complexes $\mathrm{CpMn}(\mathrm{CO}){ }_{2} \mathrm{CXY}\left(\mathrm{X}=\mathrm{Y}=\mathrm{Me},{ }^{65} 1.87 \AA ; \mathrm{X}=\mathrm{Y}=\mathrm{Ph},{ }^{66} 1.89 \AA\right.$; $\mathrm{X}=\mathrm{F}, \mathrm{Y}=\mathrm{Ph},{ }^{67} 1.83 \AA ; \mathrm{X}=\mathrm{OEt}, \mathrm{Y}=\mathrm{Ph},{ }^{68} 1.87 \AA$ ). This may result from two reasons: one is the steric repulsion among the bulky substituents; the other is the very weak $\mathrm{Mn} \rightarrow \mathrm{C}$ back bonding in $\mathbf{2 0}$ due to the relatively high energy of the formal empty $\mathrm{p}(\pi)$ orbital of the Nheterocyclic carbene carbon, which is increased by the $\mathrm{N} \rightarrow \mathrm{C}$ bond. ${ }^{4 a, 69}$ In this respect, Nheterocyclic carbenes are different from the usual carbenes, which exhibit rather strong 
$\mathrm{M} \rightarrow \mathrm{C}$ back bonding. ${ }^{68,70}$ The manganese atom in $\mathbf{2 0}$ is out of the carbene plane $(0.41 \AA)$ and the dihedral angle between the carbene plane and the chelating ligand plane is $108.8^{\circ}$. The $\mathrm{Mn}(1)-\mathrm{N}(3)$ bond length in $\mathbf{2 0}$ is $2.06 \AA$ close to those reported in Mn(II) amides. ${ }^{71}$

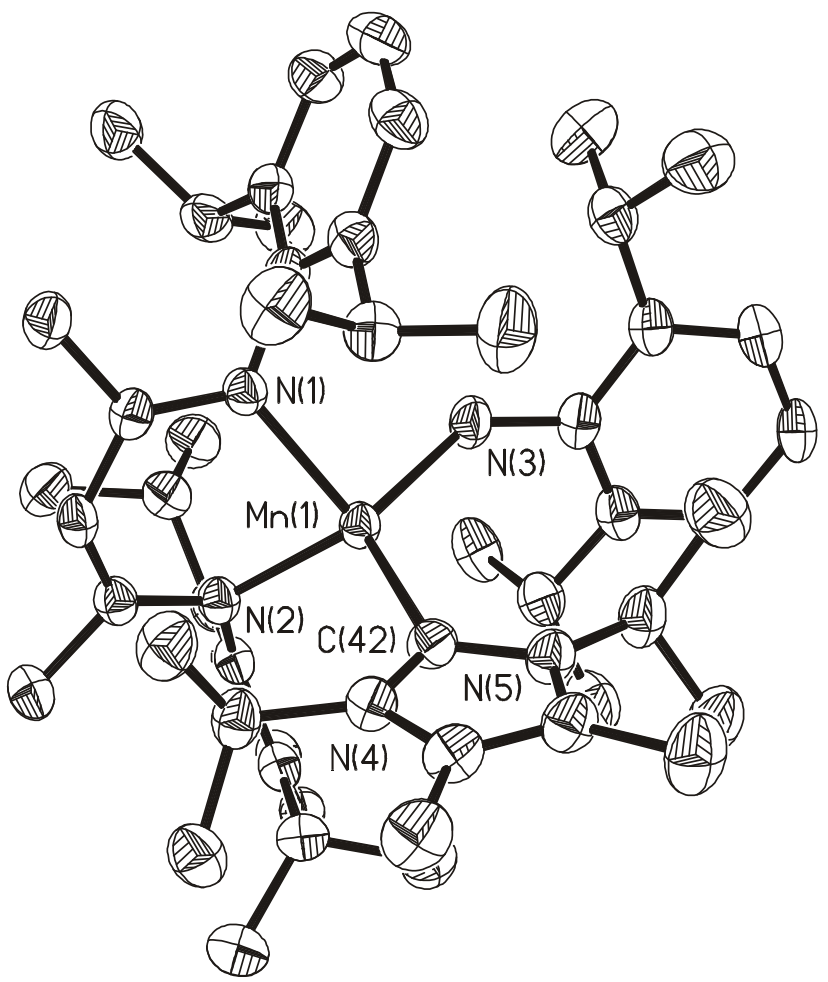

Figure 17. Molecular structure of 20 (50\% probability ellipsoids). Hydrogen atoms are omitted for clarity.

Table 10. Selected bond lengths $(\AA)$ and bond angles $\left(^{\circ}\right)$ for compound 20

\begin{tabular}{lllr}
\hline $\mathrm{Mn}(1)-\mathrm{N}(1)$ & $2.166(2)$ & $\mathrm{N}(3)-\mathrm{Mn}(1)-\mathrm{N}(1)$ & $99.25(7)$ \\
$\mathrm{Mn}(1)-\mathrm{N}(2)$ & $2.133(2)$ & $\mathrm{N}(2)-\mathrm{Mn}(1)-\mathrm{N}(1)$ & $88.94(7)$ \\
$\mathrm{Mn}(1)-\mathrm{N}(3)$ & $2.055(2)$ & $\mathrm{N}(3)-\mathrm{Mn}(1)-\mathrm{C}(42)$ & $117.46(8)$ \\
$\mathrm{Mn}(1)-\mathrm{C}(42)$ & $2.270(2)$ & $\mathrm{N}(2)-\mathrm{Mn}(1)-\mathrm{C}(42)$ & $111.68(8)$ \\
$\mathrm{N}(3)-\mathrm{Mn}(1)-\mathrm{N}(2)$ & $123.25(7)$ & $\mathrm{N}(1)-\mathrm{Mn}(1)-\mathrm{C}(42)$ & $109.83(7)$ \\
\hline
\end{tabular}




\subsection{Synthesis, Characterization and Reactivity of the First Complex with Three- coordinate Manganese(I) 21}

\subsubsection{Synthesis and Spectroscopic Characterization of $[\mathrm{LMn}]_{2}(21)$}

The reduction of the complex $[\operatorname{LMn}(\mu-\mathrm{I})]_{2}(\mathbf{1 8})$ with $\mathrm{Na} / \mathrm{K}$ alloy in toluene at room temperature affords $[\mathrm{LMn}]_{2}(\mathbf{2 1})$ with three-coordinate manganese(I) as dark red crystals in about $15 \%$ yield (Scheme 13). Compound 21 is thermally stable and melts without decomposition at $154-156{ }^{\circ} \mathrm{C}$. Interestingly, the molecular ion peak of 21 at $\mathrm{m} / \mathrm{z} 944$ can be seen, albeit in low intensity (5\%) in the EI mass spectrum. The most intense peak at $\mathrm{m} / \mathrm{z} 472$ corresponds to the monomeric unit.

\section{Scheme 13}

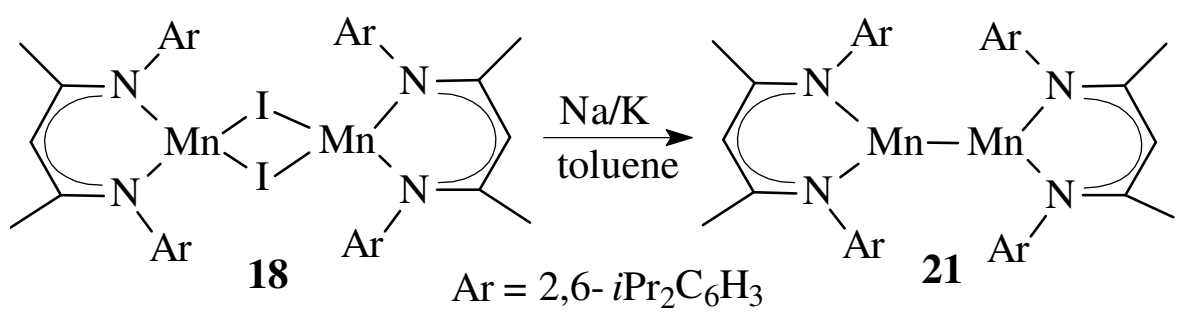

\subsubsection{X-ray Solid-state Structural Analysis of Compound 21}

Single crystals of $\mathbf{2 1}$ suitable for X-ray structural analysis were obtained from toluene at 4 ${ }^{\circ} \mathrm{C}$. The X-ray single-crystal structural analysis of $\mathbf{2 1}$ reveals its dimeric nature with a central $\mathrm{Mn}_{2}{ }^{2+}$ core (Figure 18). Each manganese is three-coordinated. The coordination environment around each manganese center consists of two nitrogen atoms of the chelating ligand and the other manganese atom in a perfectly trigonal planar environment and the sum of the bond angles around each manganese averages to $359.4^{\circ}$. Compound 21 contains two $\mathrm{C}_{3} \mathrm{~N}_{2} \mathrm{Mn}$ sixmembered rings, where the $\mathrm{C}_{3} \mathrm{~N}_{2}$ portions of the rings are planar, the manganese atoms are significantly out of the planes (av. $0.53 \AA$ ). The two six-membered rings are nearly orthogonal to each other as shown by a dihedral angle of $80.6^{\circ}$. The $\mathrm{Mn}-\mathrm{N}$ bonds (av. 2.10 $\AA$ ) are slightly longer than that observed in $\mathbf{1 8}$ (av. $2.07 \AA$ ). Interestingly, the angle N-Mn-N $\left(89.82^{\circ}\right)$ in 21 is more acute than that observed in $\mathbf{1 8}$ (av. 94.59 $9^{\circ}$. The Mn-Mn distance in 21 $(2.72 \AA)$ is significantly shorter than that in $\mathrm{Mn}_{2}(\mathrm{CO})_{10}{ }^{18}(2.90 \AA)$ with a formal oxidation state of 0 , a little longer than that in $\mathrm{Mn}_{2}(\mathrm{CO})_{7}\left(\mu-\mathrm{S}_{2}\right)^{72}(2.67 \AA)$ with a formal oxidation state 
of +1 , which compares well to that observed in $\mathrm{Mn}_{2}\left(\mathrm{CH}_{2} \mathrm{CMe}_{2} \mathrm{Ph}\right)_{4}{ }^{46}(2.72 \AA)$ with a formal oxidation state of +2 . This indicates that the $\mathrm{Mn}-\mathrm{Mn}$ bond in $\mathbf{2 1}$ is weak and considered to be highly reactive.

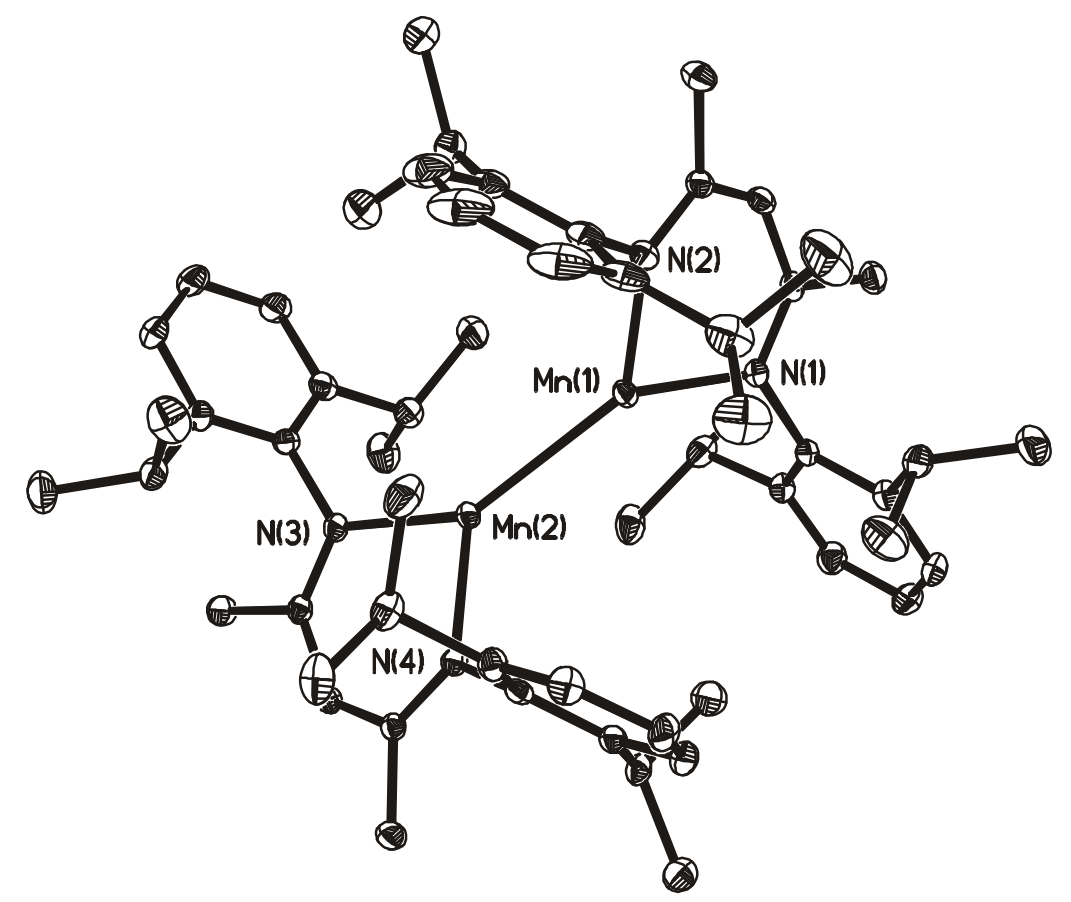

Figure 18. Molecular structure of 21 (30\% probability ellipsoids). Hydrogen atoms are omitted for clarity.

Table 11. Selected bond lengths $(\AA)$ and bond angles $\left({ }^{\circ}\right)$ for compound 21

\begin{tabular}{lllr}
\hline $\mathrm{Mn}(1)-\mathrm{N}(1)$ & $2.097(2)$ & $\mathrm{N}(1)-\mathrm{Mn}(1)-\mathrm{N}(2)$ & $89.72(9)$ \\
$\mathrm{Mn}(1)-\mathrm{N}(2)$ & $2.101(2)$ & $\mathrm{N}(1)-\mathrm{Mn}(1)-\mathrm{Mn}(2)$ & $139.96(6)$ \\
$\mathrm{Mn}(1)-\mathrm{Mn}(2)$ & $2.721(1)$ & $\mathrm{N}(2)-\mathrm{Mn}(1)-\mathrm{Mn}(2)$ & $129.67(6)$ \\
$\mathrm{Mn}(2)-\mathrm{N}(3)$ & $2.116(2)$ & $\mathrm{N}(3)-\mathrm{Mn}(2)-\mathrm{N}(4)$ & $89.92(8)$ \\
$\mathrm{Mn}(2)-\mathrm{N}(4)$ & $2.094(2)$ & $\mathrm{N}(3)-\mathrm{Mn}(2)-\mathrm{Mn}(1)$ & $141.26(6)$
\end{tabular}

\subsubsection{Reactivity of Compound 21 and the Derivative $[\mathrm{LMn}(\mu-\mathrm{O})]_{2}(22)$}

Stirring a mixture of $\mathbf{2 1}$ and excess $\mathrm{KMnO}_{4}$ in toluene at room temperature for $2 \mathrm{~d}$ smoothly afforded the dimeric oxide $[\operatorname{LMn}(\mu-\mathrm{O})]_{2}(\mathbf{2 2})$ as red crystals. Interestingly, the molecular ion peak of 22 in the EI-MS appears as the most intense peak at $m / z 976$. 


\section{Scheme 14}

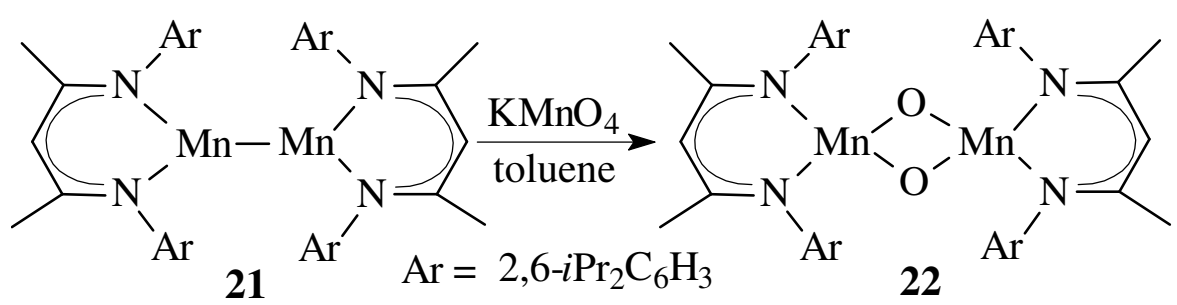

The molecular structure of $\mathbf{2 2}$ is shown in Figure 19. This compound contains two peripheral six-membered $\mathrm{C}_{3} \mathrm{~N}_{2} \mathrm{Mn}$ rings and one central four-membered $\mathrm{Mn}_{2} \mathrm{O}_{2}$ ring. Each manganese center is tetrahedrally coordinated. The dihedral angle between the six- and the four-membered rings is $39.9^{\circ}$. Compound 22 is the first example of bis $(\mu-\mathrm{O})$ complexes with four-coordinate $\mathrm{Mn}(\mathrm{III})$ centers. The Mn-O distances in 22 average to $1.82 \AA$ and are in the normal range $(1.79-1.86 \AA)$ for Mn-O bond lengths observed in other compounds. ${ }^{73}$ The Mn-Mn distance in 22 is $2.66 \AA$, which is the shortest separation observed in $\operatorname{bis}(\mu-\mathrm{O})$ dimanganese(III) complexes. ${ }^{73}$

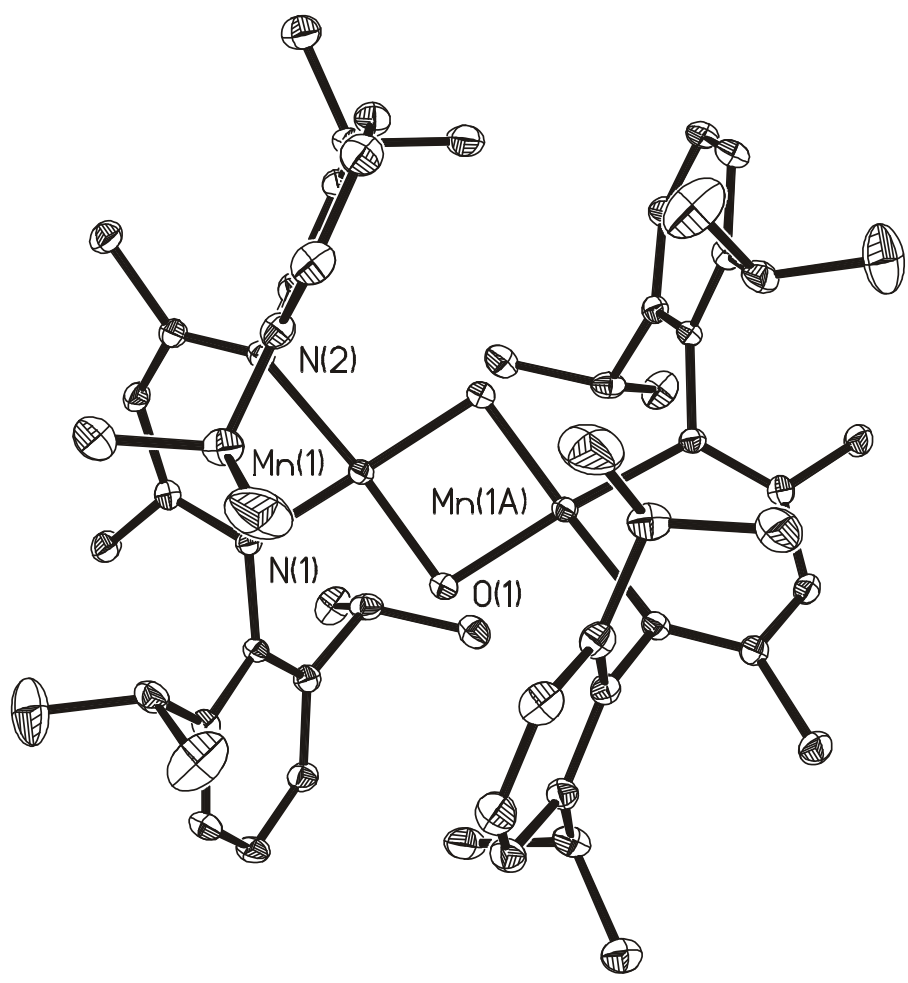

Figure 19. Molecular structure of 22 (30\% probability ellipsoids). Hydrogen atoms are omitted for clarity. 
Table 12. Selected bond lengths $(\AA)$ and bond angles $\left(^{\circ}\right)$ for compound 22

\begin{tabular}{lllr}
\hline $\mathrm{Mn}(1)-\mathrm{N}(1)$ & $2.013(2)$ & $\mathrm{N}(1)-\mathrm{Mn}(1)-\mathrm{N}(2)$ & $90.28(8)$ \\
$\mathrm{Mn}(1)-\mathrm{N}(2)$ & $2.013(2)$ & $\mathrm{N}(1)-\mathrm{Mn}(1)-\mathrm{O}(1)$ & $96.64(8)$ \\
$\mathrm{Mn}(1)-\mathrm{O}(1)$ & $1.809(2)$ & $\mathrm{N}(2)-\mathrm{Mn}(1)-\mathrm{O}(1)$ & $157.90(9)$ \\
$\mathrm{Mn}(1)-\mathrm{O}(1 \mathrm{~A})$ & $1.827(2)$ & $\mathrm{O}(1)-\mathrm{Mn}(1)-\mathrm{O}(1 \mathrm{~A})$ & $85.99(7)$ \\
$\mathrm{Mn}(1)-\mathrm{Mn}(1 \mathrm{~A})$ & $2.659(1)$ & $\mathrm{N}(1)-\mathrm{Mn}(1)-\mathrm{O}(1 \mathrm{~A})$ & $156.26(8)$ \\
\hline
\end{tabular}

\subsection{Synthesis and Structure of the Dinuclear Manganese Compound Containing a Bulky Diamide Ligand}

Considering the recent success in the synthesis of complexes of main-group elements, transition metals and lanthanides with unusual properties with the bulky $\beta$-diketiminate ligand $\left[\mathrm{HC}(\mathrm{CMeNAr})_{2}\right]\left(\mathrm{Ar}=2,6-i \mathrm{Pr}_{2} \mathrm{C}_{6} \mathrm{H}_{3}\right),{ }^{35}$ we were interested in investigating the behavior of the bulky chelating diamide ligand $\left[\mathrm{ArN}\left(\mathrm{CH}_{2}\right)_{3} \mathrm{NAr}\right]^{2-}$, comparable in steric properties with the $\beta$-diketiminate ligand and expected to result in interesting new organometallic chemistry. The bulky chelating diamide ligand $\left[\mathrm{ArN}\left(\mathrm{CH}_{2}\right)_{3} \mathrm{NAr}\right]^{2-}$ was previously used by McConville and co-workers as a non-Cp ligand to prepare group 4 complexes, which can catalyze olefin polymerization under 'living' conditions. ${ }^{74}$ Cloke and Roesky et al. reported on lanthanide complexes bearing this ligand. ${ }^{75}$ Recently we isolated the aluminum hydride $\left[\mathrm{ArN}\left(\mathrm{CH}_{2}\right)_{3} \mathrm{NAr}\right] \mathrm{LAlH}\left(\mathrm{NMe}_{3}\right)$ and its derivatives $\left\{\left[\mathrm{ArNH}\left(\mathrm{CH}_{2}\right)_{3} \mathrm{NAr}\right] \mathrm{Al}\right\}_{2}(\mu-\mathrm{E})_{2}(\mathrm{E}=\mathrm{S}, \mathrm{Se}$ and $\mathrm{Te})$ by hydrogen transfer from chalcogen to nitrogen. $^{76}$

\subsubsection{Synthesis and Spectroscopic Characterization of $\left[\mathrm{ArN}\left(\mathrm{CH}_{2}\right)_{3} \mathrm{NAr}\right]\left[\mathrm{Li}\left(\mathrm{OEt}_{2}\right)\right]_{2}$} (23) and $\mathrm{Mn}_{2}\left[\mathrm{ArN}\left(\mathrm{CH}_{2}\right)_{3} \mathrm{NAr}\right]_{2}(24)$

The lithiation of $\operatorname{ArNH}\left(\mathrm{CH}_{2}\right)_{3} \mathrm{NHAr}$ with 2 equiv. of MeLi in diethyl ether smoothly proceeded to afford $\left[\mathrm{ArN}\left(\mathrm{CH}_{2}\right)_{3} \mathrm{NAr}\right]\left[\mathrm{Li}\left(\mathrm{OEt}_{2}\right)\right]_{2}$ (23) as colorless crystals in high yield (Scheme 15). The existence of the coordinated diethyl ether molecules has been confirmed by ${ }^{1} \mathrm{H}$ NMR, elemental analysis, and X-ray solid-state structural analysis. The dilithium salt $\mathbf{2 3}$ is soluble in diethyl ether and stable under an inert atmosphere and is a useful reagent for metathesis reactions with metal halides. 


\section{Scheme 15}
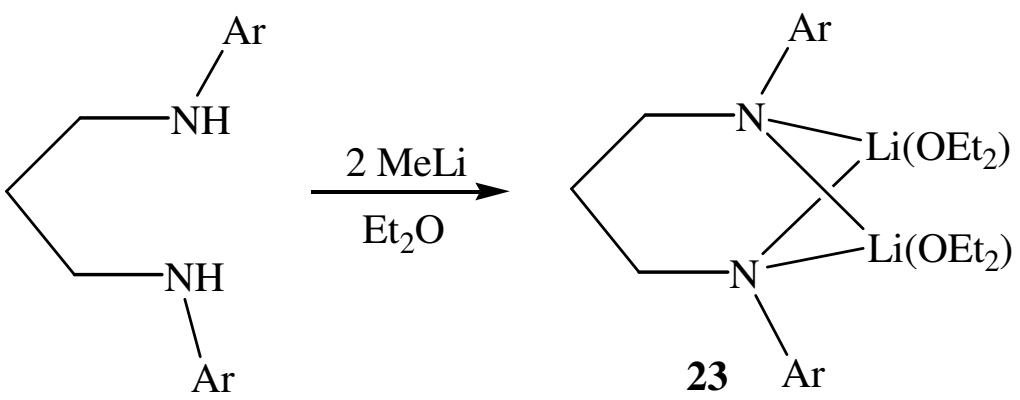

$\mathrm{Ar}=2,6-i \mathrm{Pr}_{2} \mathrm{C}_{6} \mathrm{H}_{3}$

The reaction of $\mathbf{2 3}$ with one equiv. of anhydrous $\mathrm{MnCl}_{2}$ in diethyl ether at low temperature smoothly provided the dimeric compound $\mathrm{Mn}_{2}\left[\mathrm{ArN}\left(\mathrm{CH}_{2}\right)_{3} \mathrm{NAr}\right]_{2}(\mathbf{2 4})$ in good yield (Scheme 16). The same compound was obtained even when 2 equiv. of $\mathrm{MnCl}_{2}$ were employed. Complex 24 is soluble in $\mathrm{CH}_{2} \mathrm{Cl}_{2}$ and THF and has a moderate solubility in diethyl ether and toluene. Compound $\mathbf{2 3}$ is a colorless solid while $\mathbf{2 4}$ is a yellow-green crystalline solid. Complexes 23 and $\mathbf{2 4}$ have been characterized by EI-MS, ${ }^{1} \mathrm{H}$ NMR, IR and X-ray solid-state structural analysis. The molecular ion peak of $\mathbf{2 4}$ in the EI mass spectrum is observed at $\mathrm{m} / \mathrm{z}$ $894(49 \%)$, followed by the most intense peak at $m / z 705\left[\mathrm{M}-\mathrm{CH}_{2} \mathrm{NAr}\right]^{+}$.

\section{Scheme 16}

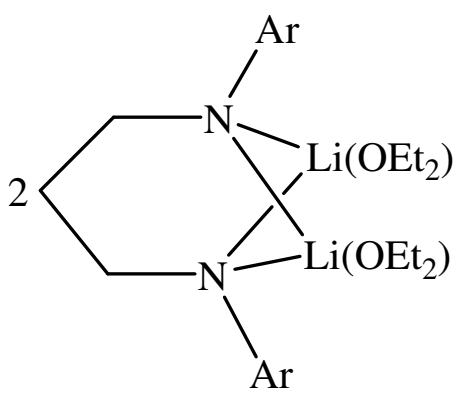

23

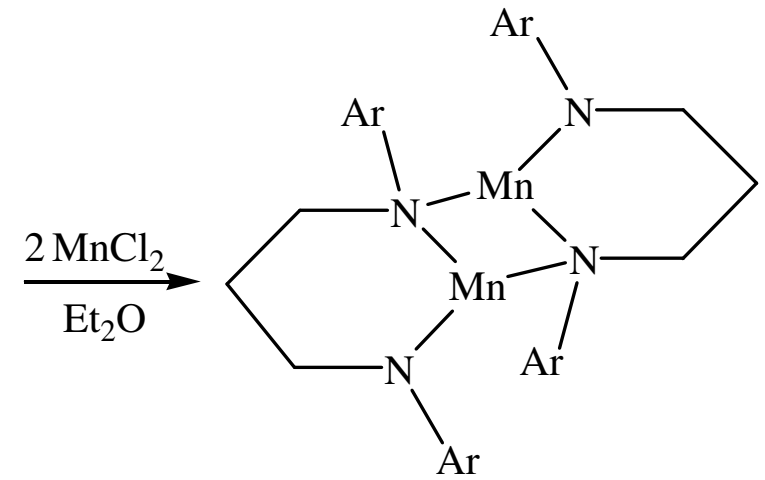

24

$$
\mathrm{Ar}=2,6-i \mathrm{Pr}_{2} \mathrm{C}_{6} \mathrm{H}_{3}
$$

\subsubsection{X-ray Solid-state Structural Analyses of Compounds 23 and 24}

The X-ray solid-state structural analysis of $\mathbf{2 3}$ (Figure 20) reveals a monomer with two three-coordinated lithium atoms. Each of the lithium atoms is bonded to two nitrogen atoms of the chelating ligand and one oxygen atom of the coordinated ether. It is better to describe the coordination sphere of the $\mathrm{Li}$ atoms as trigonal planar rather than trigonal pyramidal. 
Two $\mathrm{C}_{3} \mathrm{~N}_{2} \mathrm{Li}$ six-membered rings are formed, one displays a boat conformation while the other is in a chair conformation. The interplanar angle between the central two $\mathrm{LiN}_{2}$ planes is $43.8^{\circ}$. The Li-N distances are in the normal range $1.94-2.15 \AA^{71}$ In addition, there are some very close contacts between $\operatorname{Li}(1), \operatorname{Li}(2)$ and various carbon and hydrogen atoms from the chelating ligand: $\mathrm{Li}(1)-\mathrm{H}(26 \mathrm{a}) 2.29(4) \AA, \mathrm{Li}(2)-\mathrm{C}(2) 2.36(2) \AA$, and $\mathrm{Li}(2)-\mathrm{H}(2 \mathrm{a}) 2.02(4) \AA$. Similar contacts have been observed in $\left[\mathrm{LiArN}\left(\mathrm{CH}_{2}\right)_{2} \mathrm{NArLi}\right]_{2}{ }^{71}$

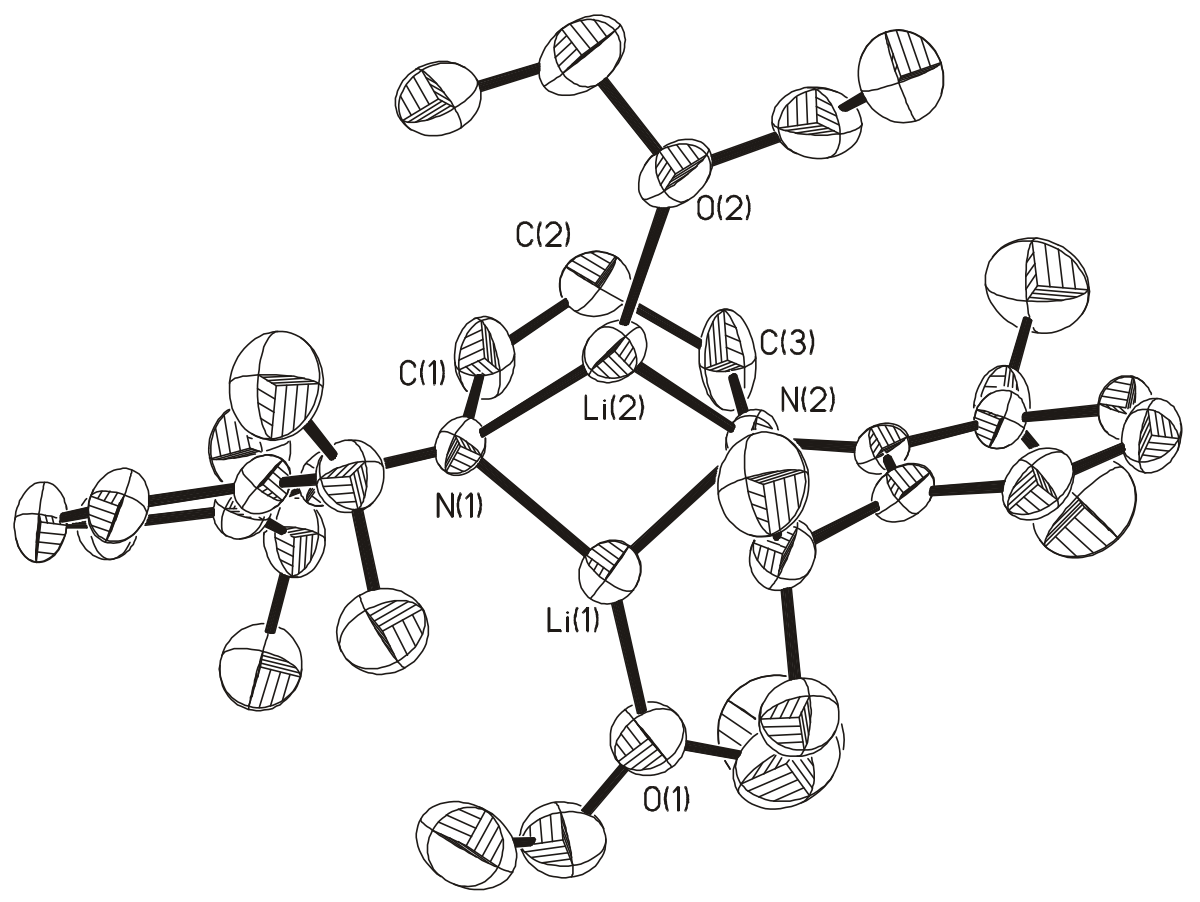

Figure 20. Molecular structure of $\mathbf{2 3}$ (50\% probability ellipsoids). Hydrogen atoms are omitted for clarity.

$\mathrm{Mn}_{2}\left[\mathrm{ArN}\left(\mathrm{CH}_{2}\right)_{3} \mathrm{NAr}\right]_{2}$ (24) crystallizes in the triclinic space group $P-1$. The dimer is formed through two bridging nitrogen atoms. The central core contains a nonplanar $\mathrm{Mn}_{2} \mathrm{~N}_{2}$ four-membered ring, which is in a butterfly configuration with the dihedral angle of $28.6^{\circ}$. This arrangement is caused by the strain of the bulky aryl groups. Each metal atom is surrounded by three nitrogen atoms and out of this plane formed by them about $0.33 \AA$, so that both metal atoms are in a trigonal pyramidal geometry. The two ligands chelate two metal atoms to fuse two six-membered $\mathrm{MnN}_{2} \mathrm{C}_{3}$ rings, which display a boat conformation with the two metal atoms at the stern and the corresponding opposite carbon atoms at the bow. The manganese atom is about $0.17 \AA$ out of the plane formed by the two carbon and two nitrogen atoms. The opposite carbon atom is about $0.72 \AA$ out of the plane. 
The ligand in complex $\mathbf{2 4}$ is both chelating and bridging, so that one of the nitrogen atoms is three-coordinate and the other four-coordinate. To the best of our knowledge, complex 24 is the first example with the diamide ligand in such a bonding mode. The terminal Mn-N distances (av. $1.93 \AA$ ) are significantly shorter than those of the corresponding bridging ones (av. Mn-N 2.10 $\AA$ ). The terminal and bridging Mn-N distances in 24 are about $0.06 \AA$ shorter than the corresponding distances in the dimeric silylamide $\mathrm{Mn}_{2}\left[\mathrm{~N}\left(\mathrm{SiMe}_{3}\right)_{2}\right]_{4}{ }^{77}$ The terminal Mn-N bond lengths are even shorter than those found in amides with two coordinate metal centers $\mathrm{Mn}\left[\mathrm{N}\left(\mathrm{SiMePh}_{2}\right)_{2}\right]_{2}(1.99 \AA) .{ }^{78}$ This possibly results from the strong $\mathrm{N} \rightarrow$ Si interaction in the silylamide. ${ }^{79}$

The Mn-Mn distance in complex 24 is $2.69 \AA$, which indicates that there is some bonding interaction between the metal centers. The distance is significantly shorter than those in the commonly planar $\mathrm{Mn}_{2} \mathrm{~N}_{2}$ four-membered rings. ${ }^{77,79}$

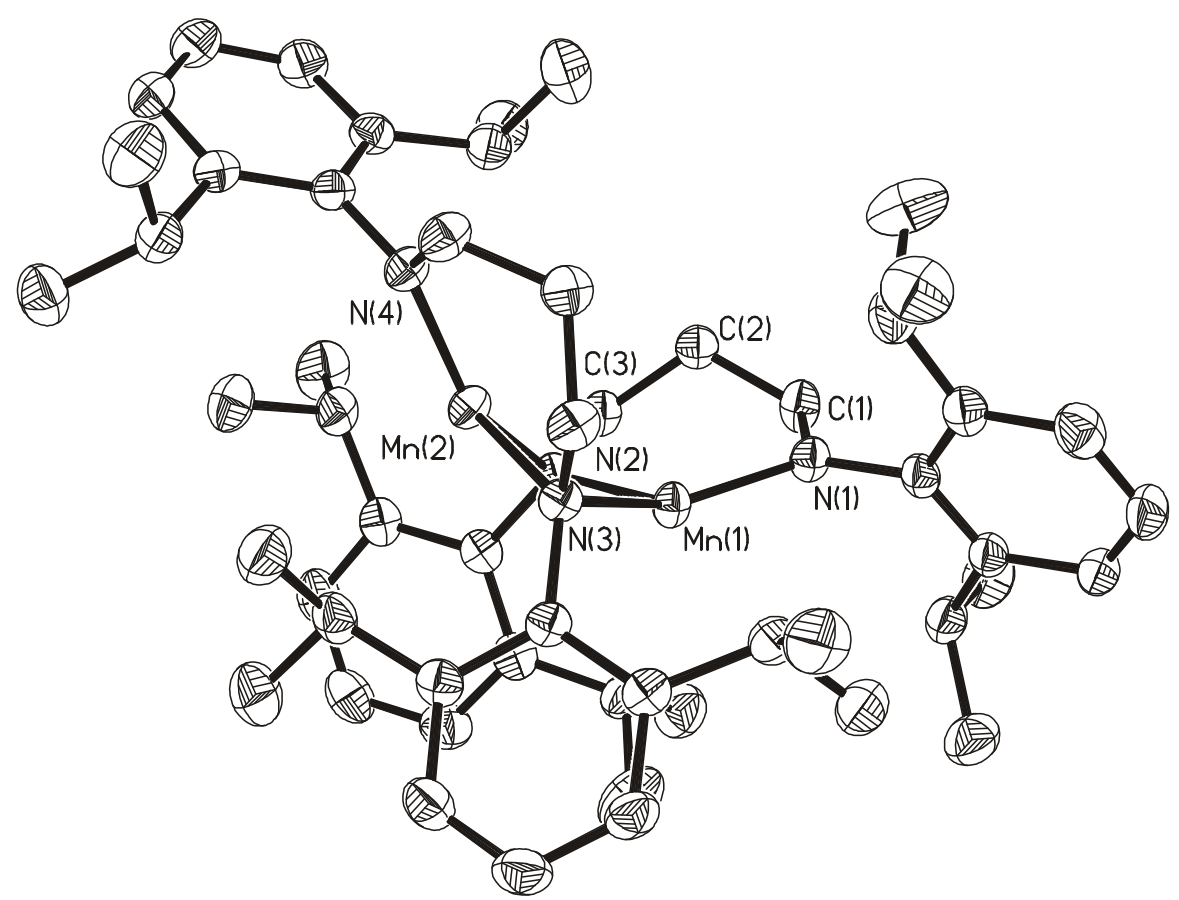

Figure 21. Molecular structure of 24 (50\% probability ellipsoids). Hydrogen atoms are omitted for clarity. 


\subsubsection{Magnetic Susceptibility Measurement of Compound 24}

The temperature dependence of the molar magnetic susceptibility $\chi_{\mathrm{m}}$ and $\chi_{\mathrm{m}} \mathrm{T}$ for compound 24 is displayed in Figure 22. The plots of $\chi_{m} \mathrm{~T}(\mathrm{~T})$-T for the compound indicate the magnetic behavior with antiferromagnetic exchange interaction between the nearest neighboring spins. The value of $\chi_{\mathrm{m}} \mathrm{T}$ at $300 \mathrm{~K}$ is estimated to $6.82 \mathrm{emu} \cdot \mathrm{K} \cdot \mathrm{mol}^{-1}$, which is lower than those of the spin-only value ( $\mathrm{s}=5 / 2 \mathrm{Mn}(\mathrm{II})_{2}$ dimer). This reveals that there exists antiferromagnetic exchange interaction between the two metal atoms.

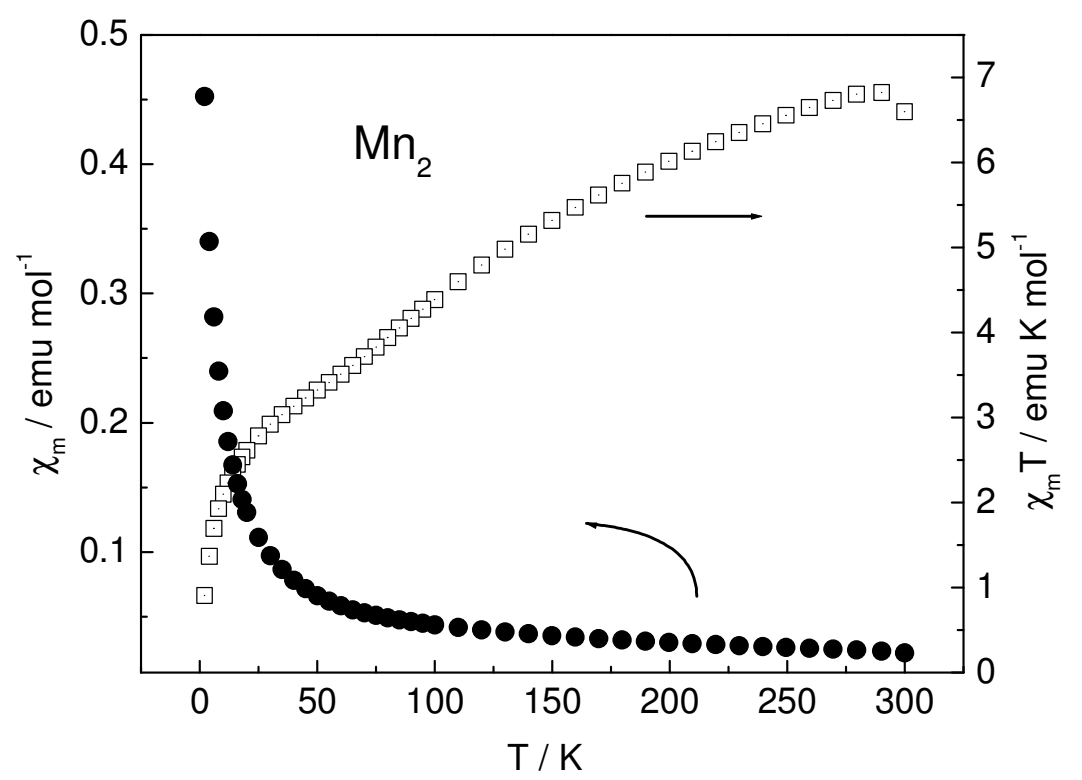

Figure 22. The plots of $\chi_{m}(T)-T$ and $\chi_{m} T(T)-T$ for compound 24 . 
Table 13. Selected bond lengths [ $\AA$ ] and bond angles $\left[^{\circ}\right]$ for compounds 23 and 24

\begin{tabular}{|c|c|c|c|}
\hline \multicolumn{4}{|c|}{ Compound 23} \\
\hline $\mathrm{Li}(1)-\mathrm{O}(1)$ & $1.894(11)$ & $\mathrm{O}(1)-\mathrm{Li}(1)-\mathrm{N}(2)$ & $118.3(5)$ \\
\hline $\mathrm{Li}(1)-\mathrm{N}(1)$ & $1.999(10)$ & $\mathrm{N}(1)-\mathrm{Li}(1)-\mathrm{N}(2)$ & $96.8(5)$ \\
\hline $\mathrm{Li}(1)-\mathrm{N}(2)$ & $1.971(10)$ & $\mathrm{O}(1)-\mathrm{Li}(1)-\mathrm{Li}(2)$ & $163.6(6)$ \\
\hline $\operatorname{Li}(1)-\operatorname{Li}(2)$ & $2.514(13)$ & $\mathrm{N}(1)-\mathrm{Li}(1)-\mathrm{Li}(2)$ & $51.9(3)$ \\
\hline $\mathrm{Li}(2)-\mathrm{N}(1)$ & $2.028(10)$ & $\mathrm{N}(2)-\mathrm{Li}(1)-\mathrm{Li}(2)$ & $52.4(3)$ \\
\hline $\mathrm{Li}(2)-\mathrm{N}(2)$ & $2.039(10)$ & $\mathrm{O}(2)-\mathrm{Li}(2)-\mathrm{N}(1)$ & $144.0(5)$ \\
\hline $\mathrm{Li}(2)-\mathrm{O}(2)$ & $1.949(10)$ & $\mathrm{O}(2)-\mathrm{Li}(2)-\mathrm{N}(2)$ & $114.2(5)$ \\
\hline $\mathrm{O}(1)-\mathrm{Li}(1)-\mathrm{N}(1)$ & $142.8(6)$ & $\mathrm{N}(1)-\mathrm{Li}(2)-\mathrm{N}(2)$ & $93.7(4)$ \\
\hline \multicolumn{4}{|c|}{ Compound 24} \\
\hline $\mathrm{Mn}(1)-\mathrm{N}(1)$ & $1.932(2)$ & $\mathrm{N}(1)-\mathrm{Mn}(1)-\mathrm{N}(2)$ & $106.79(10)$ \\
\hline $\operatorname{Mn}(1)-N(2)$ & $2.126(3)$ & $\mathrm{N}(1)-\mathrm{Mn}(1)-\mathrm{N}(3)$ & $146.55(9)$ \\
\hline $\mathrm{Mn}(1)-\mathrm{N}(3)$ & $2.078(3)$ & $\mathrm{N}(2)-\mathrm{Mn}(1)-\mathrm{N}(3)$ & $96.72(10)$ \\
\hline $\operatorname{Mn}(1)-\operatorname{Mn}(2)$ & $2.690(2)$ & $\mathrm{N}(1)-\mathrm{Mn}(1)-\mathrm{Mn}(2)$ & $133.93(8)$ \\
\hline $\mathrm{Mn}(2)-\mathrm{N}(2)$ & $2.093(3)$ & $\mathrm{N}(2)-\mathrm{Mn}(1)-\mathrm{Mn}(2)$ & $49.86(8)$ \\
\hline $\operatorname{Mn}(2)-N(3)$ & $2.128(3)$ & $\mathrm{N}(3)-\mathrm{Mn}(1)-\mathrm{Mn}(2)$ & $51.07(8)$ \\
\hline $\operatorname{Mn}(2)-N(4)$ & $1.935(2)$ & $\operatorname{Mn}(1)-N(2)-M n(2)$ & $79.20(9)$ \\
\hline
\end{tabular}




\section{Summary and Outlook}

\subsection{Summary}

In this thesis, $\mathrm{N}$-heterocyclic carbenes, $\beta$-diketiminates and diamide ligands have been employed as supporting moieties for manganese compounds. The experimental results demonstrate that steric bulk and additional intramolecular coordination of these ligands can stabilize some unusual and unique compounds, which otherwise are inaccessible. In addition, these compounds may be useful as starting materials for further reactions.

The stable N-heterocyclic carbene adducts $\left\{[\mathrm{C}(\mathrm{Me}) \mathrm{N}(i \mathrm{Pr})]_{2} \mathrm{C}\right\}_{2} \mathrm{MnX}_{2}(\mathrm{X}=\mathrm{Cl}(\mathbf{2}), \mathrm{I}(\mathbf{3})$, $\mathrm{MeCOO}$ (4)) were obtained from the reactions of the $\mathrm{N}$-heterocyclic carbene $[\mathrm{C}(\mathrm{Me}) \mathrm{N}(i \mathrm{Pr})]_{2} \mathrm{C}(\mathbf{1})$ and the corresponding manganese(II) reagents in THF, respectively. The X-ray solid-state structural analyses show that all complexes $\mathbf{2}-\mathbf{4}$ are monomeric and the $\mathrm{N}$-heterocyclic carbene ligands in these complexes are differently arranged around the central metal atoms.

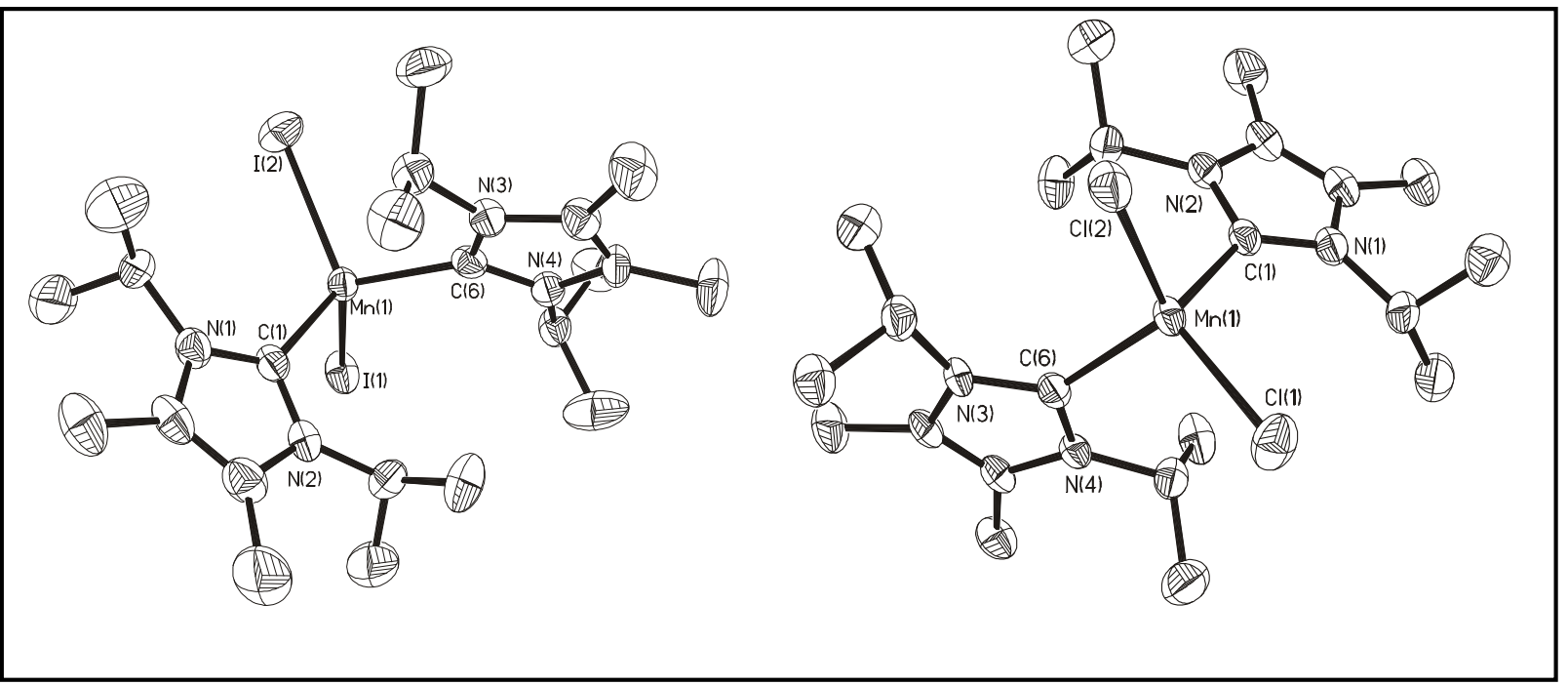

Structures of $\mathbf{2}$ and $\mathbf{3}$

The metalate compound $\mathrm{LMn}(\mu-\mathrm{Cl})_{2} \mathrm{Li}\left(\mathrm{OEt}_{2}\right)_{2}(7)\left(\mathrm{L}=\mathrm{HC}(\mathrm{CMeNAr})_{2}, \mathrm{Ar}=2,6-i \mathrm{PrC}_{6} \mathrm{H}_{3}\right)$ and dimeric compound $[\mathrm{LMn}(\mu-\mathrm{Cl})]_{2}(\mathbf{8})$ were synthesized from the reaction of $\mathrm{MnCl}_{2}$ with $\operatorname{LLi}\left(\mathrm{OEt}_{2}\right)$ (5) and LK (6) in diethyl ether, respectively. However, the reaction of $\mathrm{MnCl}_{2}(\mathrm{THF})_{1.5}$ and $\mathrm{LK}$ (6) afforded the trinuclear complex $\operatorname{LMn}(\mu-\mathrm{Cl})_{2} \mathrm{Mn}(\mathrm{THF})_{2}(\mu-$ $\mathrm{Cl})_{2} \mathrm{MnL}(9)$ in THF. This obviously indicates the reaction is solvent dependent. Attempts to prepare the di- $\beta$-diketiminate complex by using 2 equiv. of 5 or $\mathbf{6}$ were unsuccessful. The 
molecular structures of compounds 7 - 9 have been determined by X-ray solid-state structural analyses.

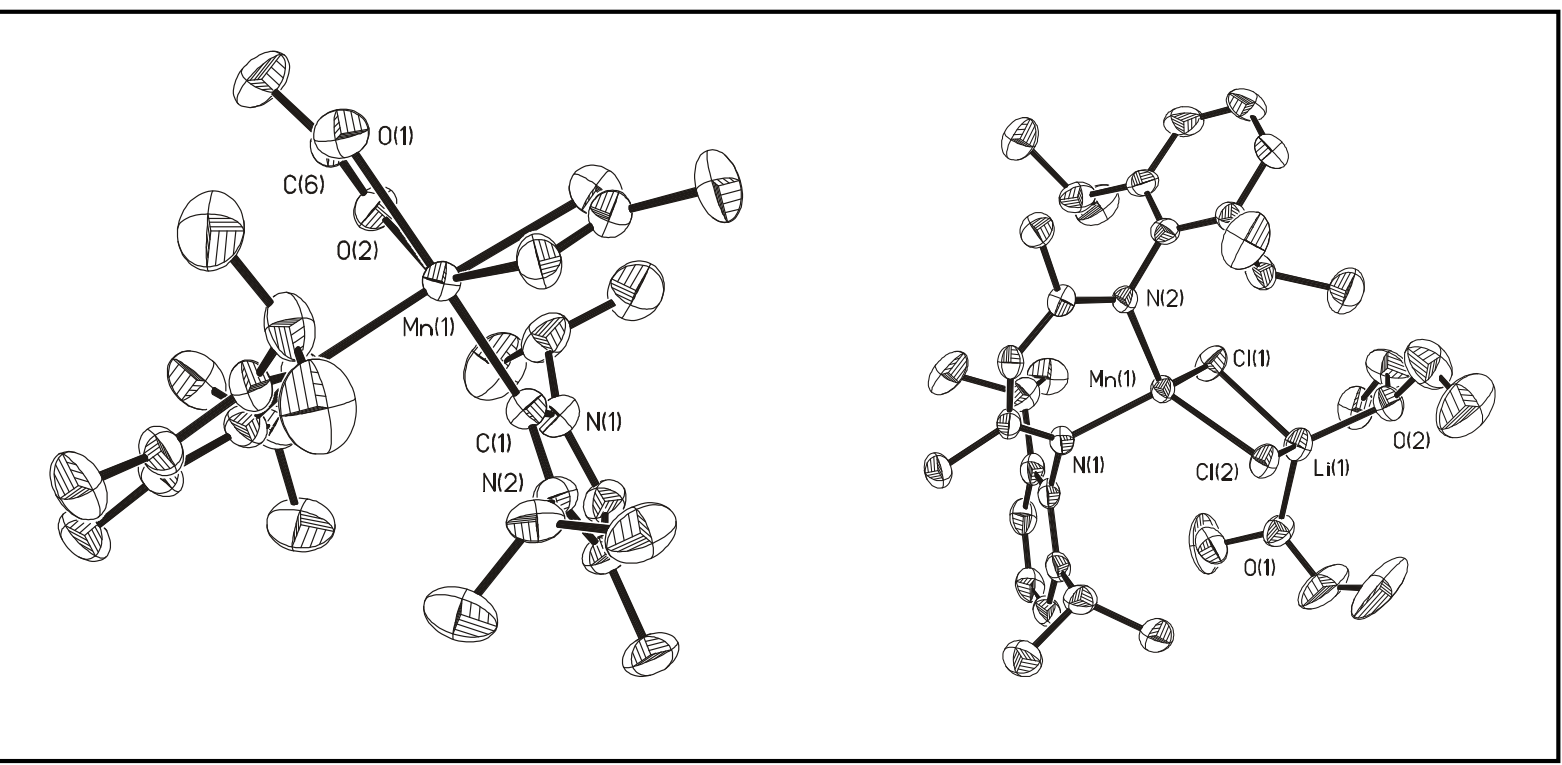

Structures of $\mathbf{4}$ and 7
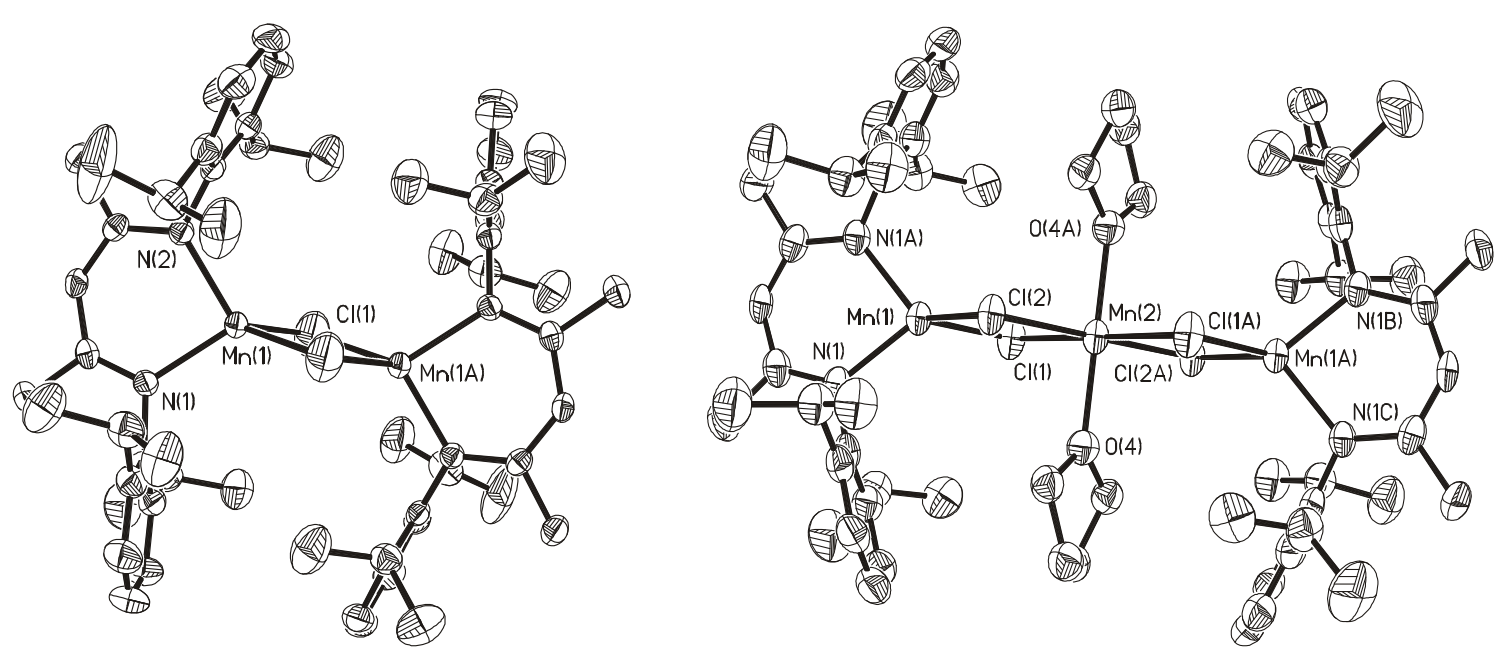

Structures of $\mathbf{8}$ and $\mathbf{9}$

When the N-heterocyclic carbene $[\mathrm{C}(\mathrm{Me}) \mathrm{N}(i \mathrm{Pr})]_{2} \mathrm{C}(\mathbf{1})$ was employed as the acceptor for the proton of $\mathrm{LH}$, the novel ionic compound $\left[\mathrm{LMnCl}_{2}\right]\left[\{\mathrm{C}(\mathrm{Me}) \mathrm{N}(i \mathrm{Pr})\}_{2} \mathrm{CH}\right](\mathbf{1 0})$ was easily obtained in high yield from the reaction of $\mathrm{LH}, \mathrm{MnCl}_{2}$ (THF) ${ }_{1.5}$ and $\mathbf{1}$ in THF. 
Treatment of $\mathbf{8}$ with $\mathrm{CpNa}, \mathrm{MeLi}$ and $\mathrm{PhLi}$ resulted in the formation of the organomanganese(II) complexes $\mathrm{LMnCp}(\mathrm{THF})(\mathbf{1 1}),[\mathrm{LMn}(\mu-\mathrm{Me})]_{2}(\mathbf{1 2})$ and $\mathrm{LMnPh}(\mathbf{1 3})$, respectively. Compound $\mathbf{1 1}$ is a rare example of a half-sandwich manganese(II) complex with the metal center of 17 valence electrons. Compound $\mathbf{1 2}$ is the first structurally characterized manganese alkyl complex containing bridging methyl groups. The structure of 13 shows a coplanar arrangement of the phenyl group and the chelating ligand around the three-coordinate metal center.
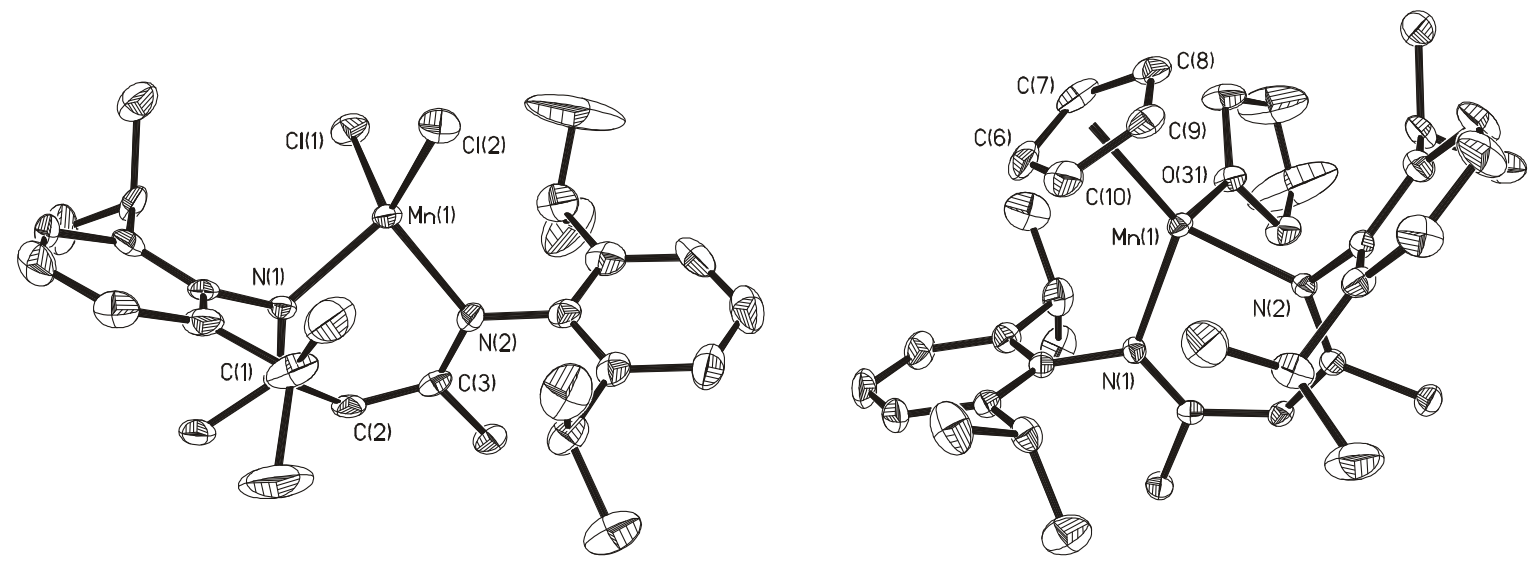

Structure of the anion of $\mathbf{1 0}$

Structure of $\mathbf{1 1}$
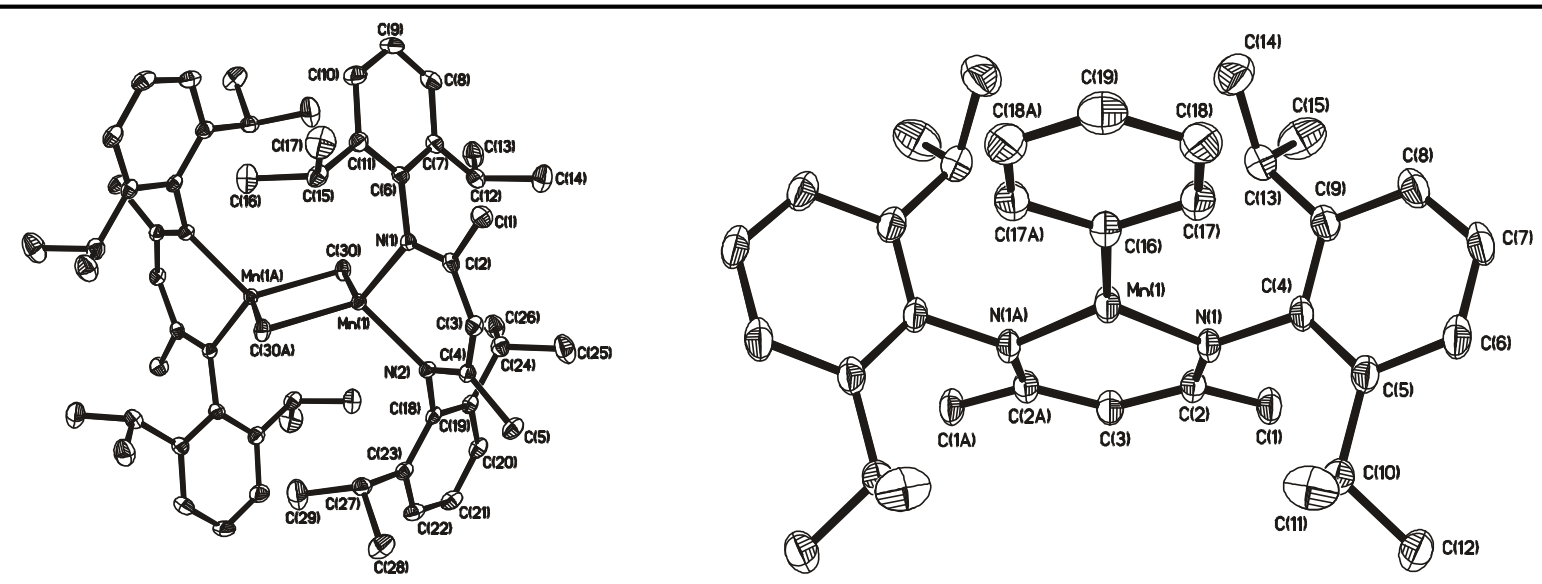

Structures of 12 and 13

The reactivity of 9 was examined. Addition of $\mathrm{C}_{3} \mathrm{H}_{5} \mathrm{MgCl}$ and PhCCLi to 9 in toluene, respectively, readily provided the monomeric compound $\mathrm{LMnC}_{3} \mathrm{H}_{5}(\mathrm{THF})$ (14) and the dimer $[\mathrm{LMn}(\mu-\mathrm{CCPh})]_{2}(\mathbf{1 5})$. Attempts to identify other species were unsuccessful. Compound 14 
is the first structurally characterized manganese complex with an $\eta^{1}$ bonding allyl group. The structure of $\mathbf{1 5}$ reveals a dimer formed by two bridging phenylethynyl groups, which is the first structurally characterized dinuclear manganese complex containing bridging alkynyl groups.

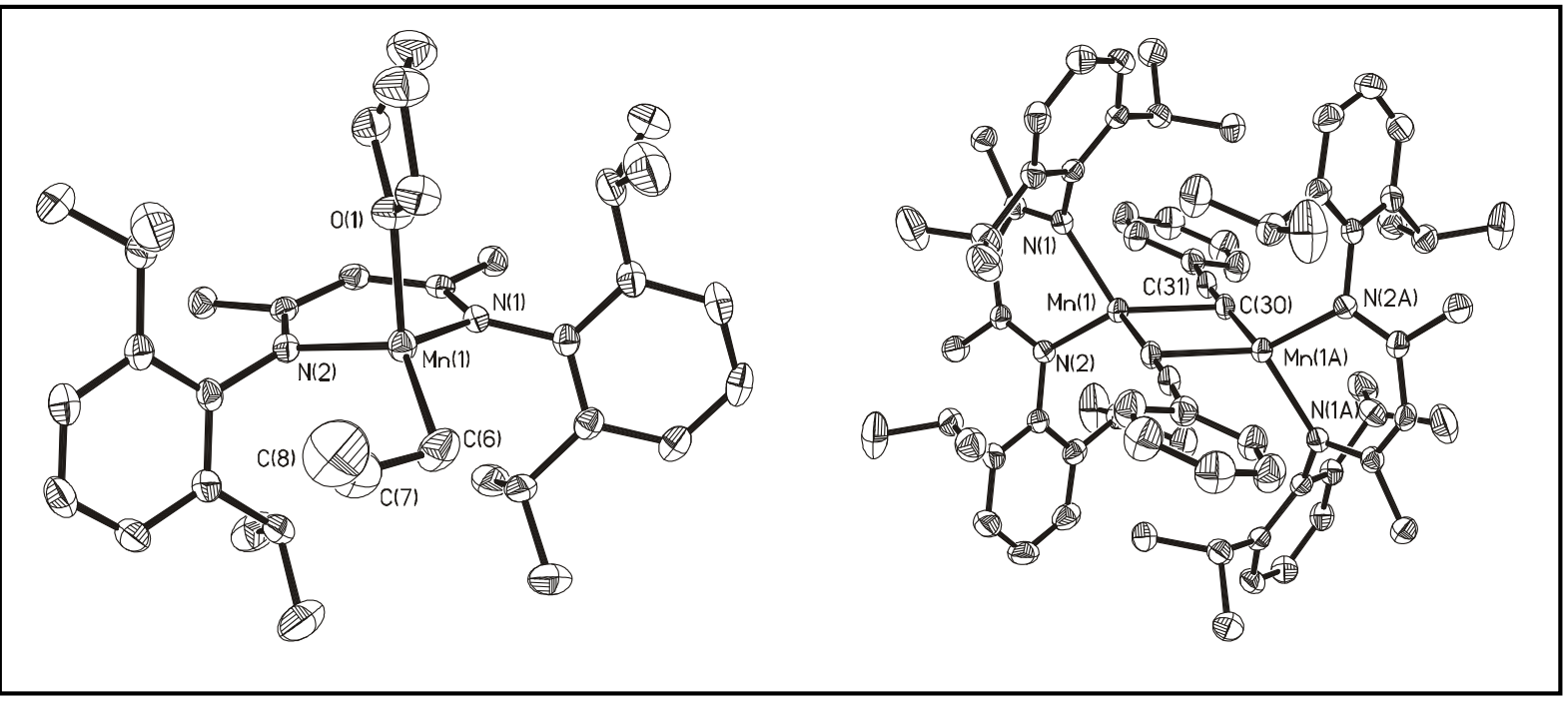

\section{Structures of $\mathbf{1 4}$ and $\mathbf{1 5}$}

$[\mathrm{LMn}(\mu-\mathrm{MeCOO})]_{2}(\mathbf{1 6})$, the first example of a doubly carboxylate-bridged complex with four-coordinate manganese(II), was prepared from the reaction of 6 and $\mathrm{Mn}(\mathrm{MeCOO})_{2}$ in THF. The structure of $\mathbf{1 6}$ is shown below.
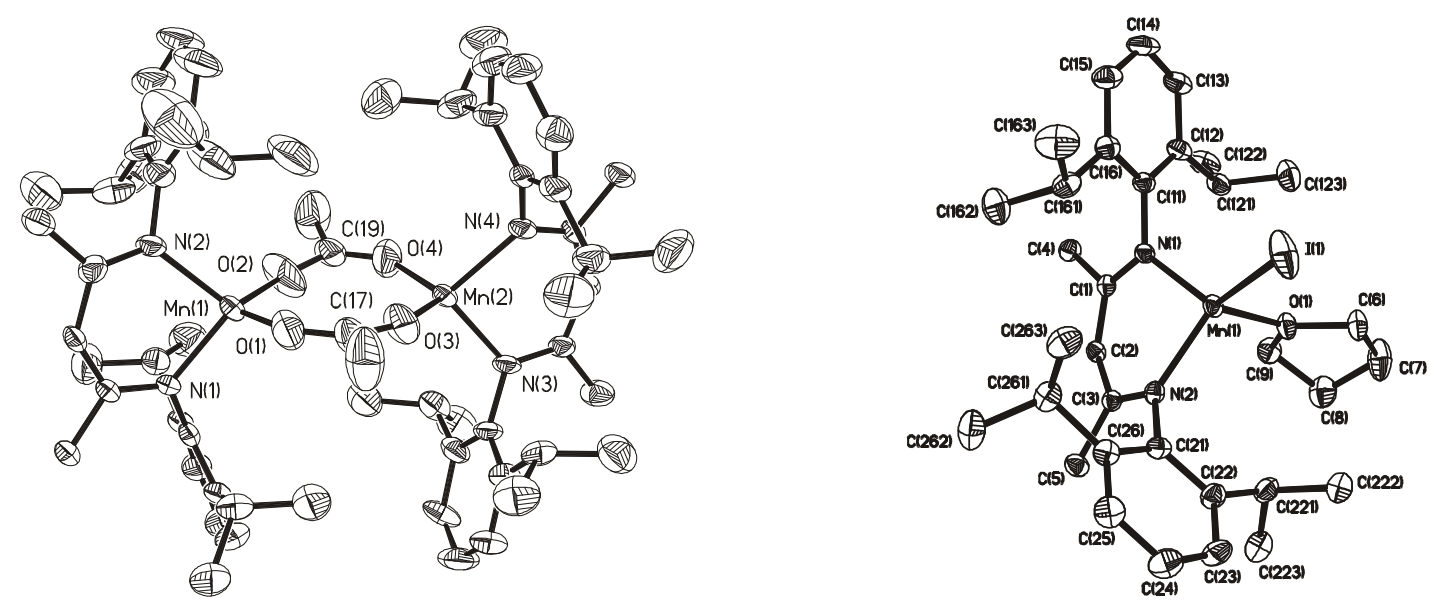

Structures of 16 and 17 
The monomeric compound LMnI(THF) (17) was isolated from the reaction of LK (6) and $\mathrm{MnI}_{2}$ in THF. Refluxing 17 in toluene and removal of the volatiles in vacuum afforded the dimer $\left[\operatorname{LMn}(\mu \text {-I) }]_{2}\right.$ (18). Compound 17 can also be obtained by dissolving 18 in THF. Displacement of the THF by the strong Lewis base $[\mathrm{C}(\mathrm{Me}) \mathrm{N}(i \mathrm{Pr})]_{2} \mathrm{C}(\mathbf{1})$ readily afforded the carbene adduct $\mathrm{LMnI}\left\{\mathrm{C}[\mathrm{N}(i \operatorname{Pr}) \mathrm{C}(\mathrm{Me})]_{2}\right\}(\mathbf{1 9})$, which can also be obtained by adding 1 to the solution of 18 in toluene. Complexes 17 and 18 have been characterized by X-ray solid-state structural analyses.

Reduction of 19 by $\mathrm{Na} / \mathrm{K}$ alloy, unexpectedly, resulted in the formation of the monomer LMnNHAr $\left\{\mathrm{C}\left[(\mathrm{N}(i \mathrm{Pr}) \mathrm{C}(\mathrm{Me})]_{2}\right\}(\mathbf{2 0})\right.$, which can also be prepared by the reaction of $\mathbf{1 9}$ with LiNHAr. The Mn-C distance is comparable to those in complexes 2 - 4.
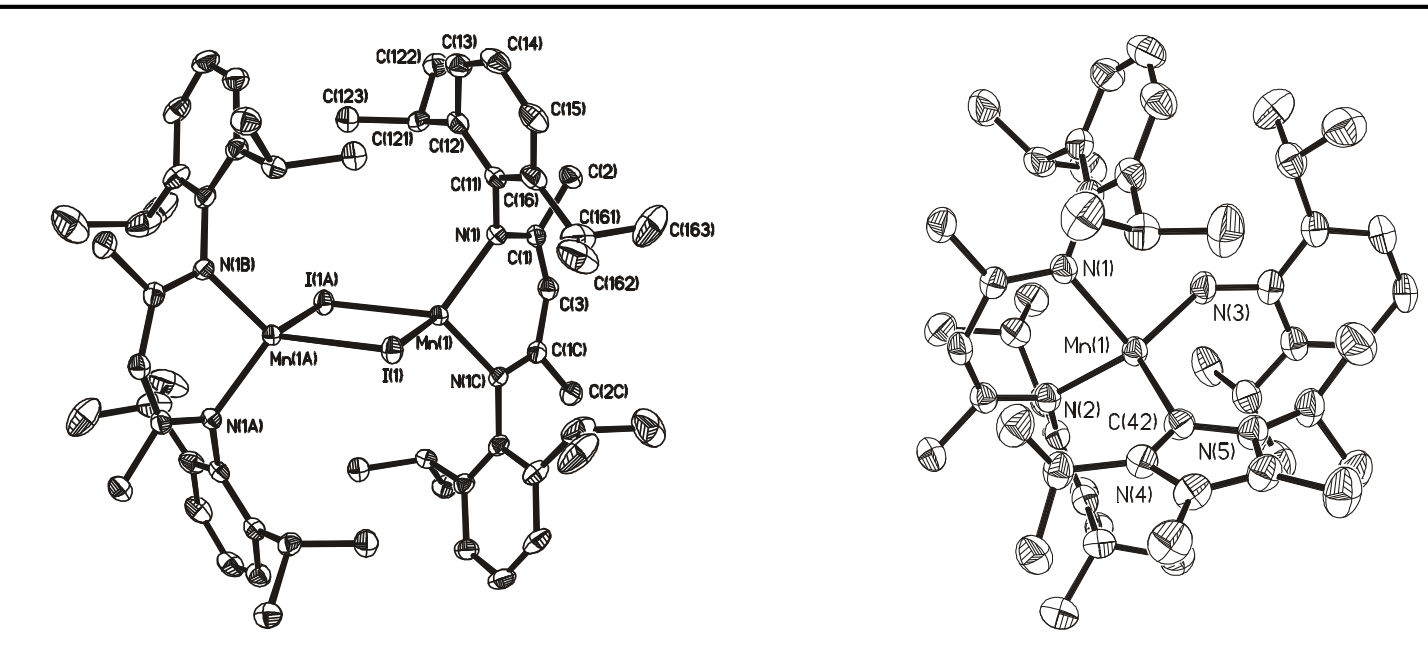

Structures of $\mathbf{1 8}$ and $\mathbf{2 0}$

Reduction of the dimeric iodide $[\operatorname{LMn}(\mu-\mathrm{I})]_{2}$ (18) with $\mathrm{Na} / \mathrm{K}$ alloy in toluene, as anticipated, afforded the first compound with three-coordinate manganese(I) $[\mathrm{LMn}]_{2}(\mathbf{2 1})$ containing a Mn-Mn bond. A mixture of 21 and excess $\mathrm{KMnO}_{4}$ in toluene afforded the dimeric oxide $[\operatorname{LMn}(\mu-\mathrm{O})]_{2}(\mathbf{2 2})$, which is the first example of a doubly oxo-bridged complex with four-coordinate $\mathrm{Mn}(\mathrm{III})$ centers.

The reaction of $\mathrm{ArNH}\left(\mathrm{CH}_{2}\right)_{3} \mathrm{NHAr}$ with 2 equiv. of MeLi in diethyl ether resulted in the formation of the monomeric dilithium salt $\left[\mathrm{ArN}\left(\mathrm{CH}_{2}\right)_{3} \mathrm{NAr}\right]\left[\mathrm{Li}\left(\mathrm{OEt}_{2}\right)\right]_{2}(\mathbf{2 3})$ in high yield. Further reaction of 23 with $\mathrm{MnCl}_{2}$ affords the complex $\mathrm{Mn}_{2}\left[\mathrm{ArN}\left(\mathrm{CH}_{2}\right)_{3} \mathrm{NAr}\right]_{2}$ (24) with three-coordinate metal centers. Both compounds 23 and 24 were characterized by X-ray solid-state structural analyses. The two complexes contain nonplanar $\mathrm{M}_{2} \mathrm{~N}_{2}$ central cores. 

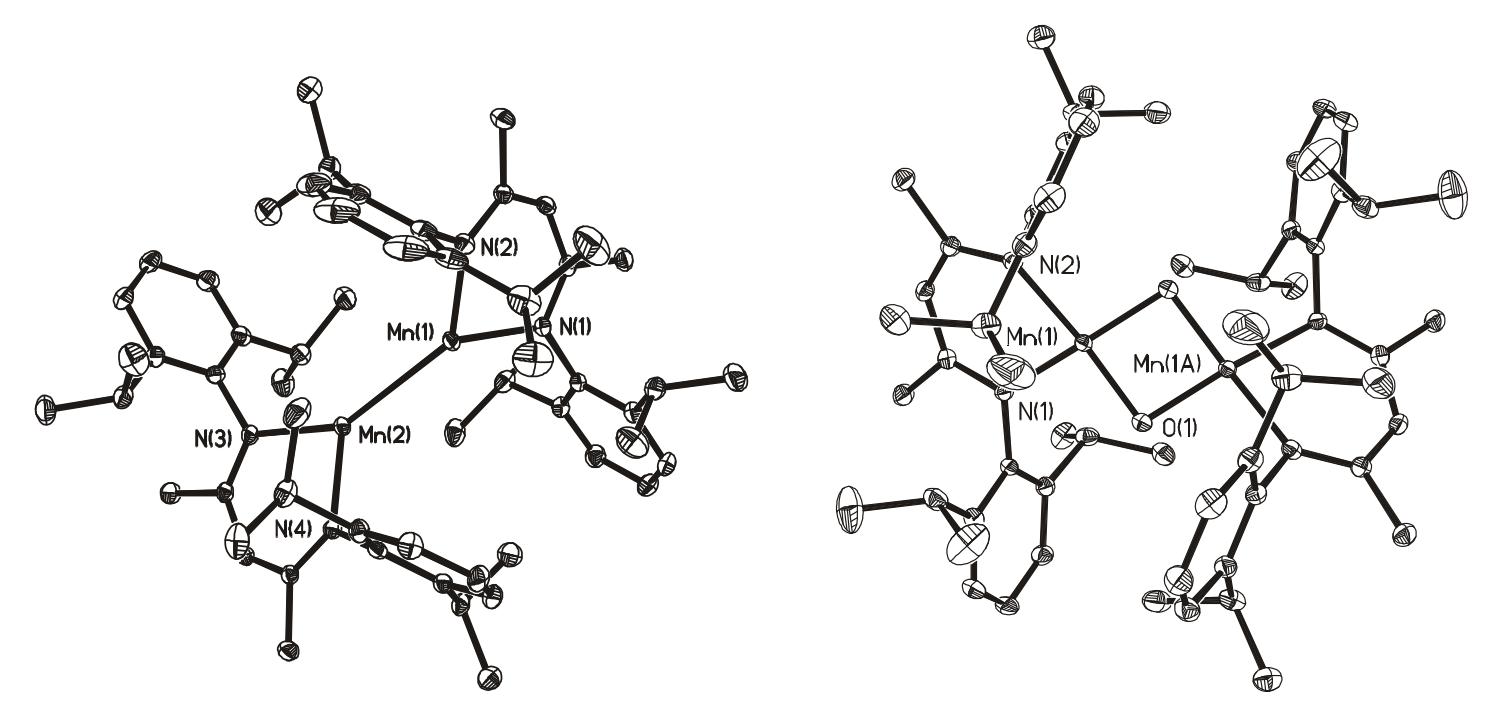

Structures of $\mathbf{2 1}$ and $\mathbf{2 2}$
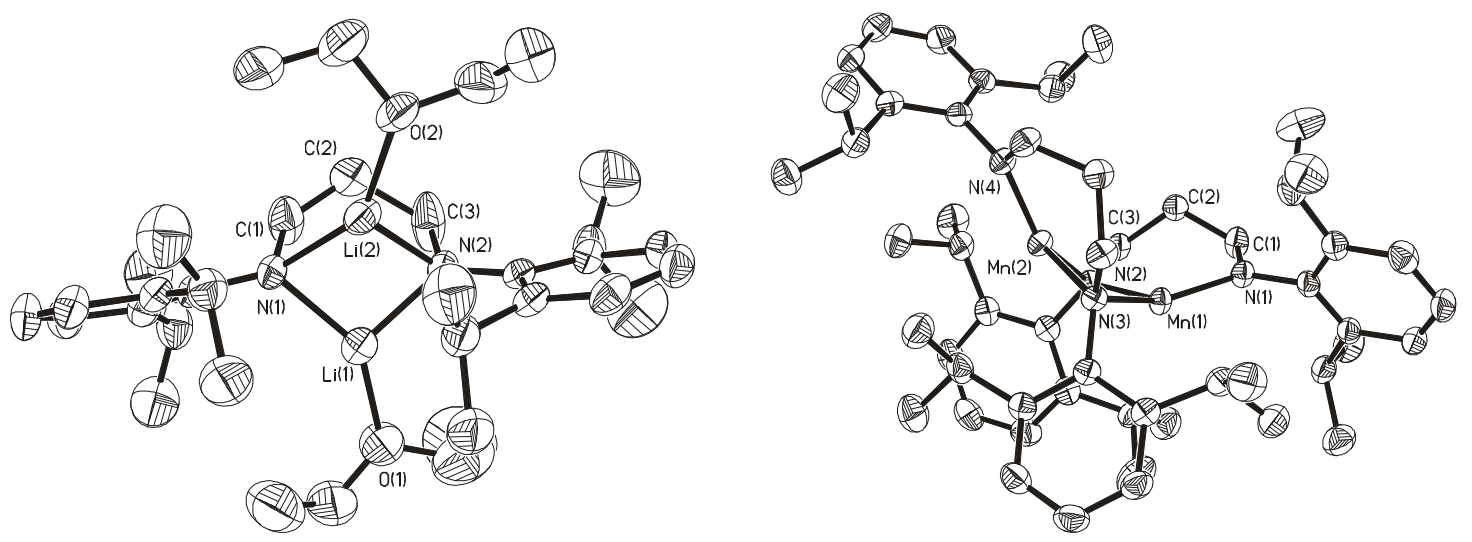

Structures of $\mathbf{2 3}$ and $\mathbf{2 4}$ 


\subsection{Outlook}

The focus of the work reported here has been on the synthesis, structure and reactivity of manganese compounds bearing N-heterocyclic carbenes, bulky diketiminates and diamide ligands. Some important compounds, for instance, the N-heterocyclic carbene adducts, the organomanganese complexes, and the first compound with three-coordinate manganese(I), were synthesized and structurally characterized for the first time. The reactivities of such compounds were checked preliminarily.

A continuation of this work would be:

- Further reactions of the manganese N-heterocyclic carbene complexes;

- Exploration of possible applications of the organomanganese complexes in organic synthesis and catalysis;

- Synthesis of compounds involving $\left[\mathrm{Mn}(\mu \text {-E) }]_{2}\right.$ cores $(\mathrm{E}=\mathrm{S}, \mathrm{Se}, \mathrm{Te})$. 


\section{Experimental Section}

\subsection{General procedures}

All experimental manipulations, unless otherwise stated, were carried out in an oxygenfree dry dinitrogen atmosphere using Schlenk glassware and techniques. ${ }^{80}$ The handling of solid samples and the preparation of samples for spectral measurements were carried out inside a MBraun MB150-GI glove-box where the $\mathrm{O}_{2}$ and $\mathrm{H}_{2} \mathrm{O}$ levels were normally kept below $1 \mathrm{ppm}$. The glassware used in all the manipulations was oven-dried at $150{ }^{\circ} \mathrm{C}$ for a minimum of $5 \mathrm{~h}$ before use, cooled to ambient temperature in vacuo, and flushed with nitrogen.

Melting points were determined in sealed capillaries on a Bühler SPA-1 apparatus.

Elemental analyses were carried out by the Analytical Laboratory of the Institute of Inorganic Chemistry at the Universität Göttingen.

${ }^{1} \mathrm{H},{ }^{7} \mathrm{Li}$, and ${ }^{13} \mathrm{C}$ NMR spectra $\left(\mathrm{CDCl}_{3}\right.$ or $\mathrm{C}_{6} \mathrm{D}_{6}$ solutions) were recorded on Bruker AM250, AM-300 and AM-500 instruments. ${ }^{7} \mathrm{Li}$ NMR spectra were recorded ${ }^{1} \mathrm{H}$ decoupled. The chemical shifts were reported in ppm with reference to external standards, more explicitly, $\mathrm{SiMe}_{4}$ for ${ }^{1} \mathrm{H}$ and ${ }^{13} \mathrm{C}$ nucleus and $\mathrm{LiCl} / \mathrm{D}_{2} \mathrm{O}$ for ${ }^{7} \mathrm{Li}$ nucleus. All NMR grade solvents were dried prior to use and the samples for measurements were freshly prepared in the glove-box.

EI-mass spectra were obtained on Finnigan MAT 8230 and Varian MAT CH5 spectrometers. Only the highest peak of the respective isotopic distribution is given.

IR spectra were recorded on a Bio-Rad Digilab FTS-7 spectrometer as Nujol mulls on $\mathrm{KBr}$ plates. Intensities were abbreviated as follows: vs (very strong), s (strong), m (medium), w (weak).

EPR spectra were recorded on a Bruker Elexsys E $500 X$-band spectrometer. All samples were measured as crystalline powders in an argon atmosphere at room temperature using a modulation frequency of $100 \mathrm{KHz}, 3-5 \mathrm{G}$ modulation amplitude, about $9.42 \mathrm{GHz}$ microwave frequency and microwave power in the range between 2 and $10 \mathrm{~mW}$ as spectrometer settings.

The magnetic susceptibility measurements were carried out with a Quantum-DesignMPMS-5S-SQUID-Magnetometer in the range from $300 \mathrm{~K}$ to $2 \mathrm{~K}$. The powdered sample was placed in a gel bucket and fixed in a non-magnetic sample holder. 
$X$-ray structure determinations: Crystals were mounted on glass fibers in a rapidly cooled perfluoropolyether. Diffraction data of structures $2,3,4,7,8,10,16,17,18,23$ and 24 were collected on a Stoe-Siemens-Huber four-circle diffractometer coupled to a Siemens CCD area detector and data of structures $9,11,12,13,14,20,21$ and 22 were collected on a Stoe IPDS II-array detector system using Mo-K $\mathrm{K}_{\alpha}$ radiation $(\lambda=0.71073 \AA)$. Data of structure 15 were collected on a Bruker three-circle diffractometer equipped with a SMART 6000 CCD detector using $\mathrm{Cu}-\mathrm{K}_{\alpha}$ radiation $(\lambda=1.54178 \AA)$. The structures were solved by direct methods using the program SHELXS- $97^{81}$ and refined using $F^{2}$ on all data by full-matrixleast-squares with SHELXL-97. ${ }^{82}$ All non-hydrogen atoms were refined anisotropically. All hydrogen atoms were included in the model at geometrically calculated positions and refined using a riding model. Crystal data for all the compounds related to the data collection, structure solution, and refinement are summarized in the tables of Section 6.

\subsection{Starting materials}

The starting materials, $[\mathrm{C}(\mathrm{Me}) \mathrm{N}(i \mathrm{Pr})]_{2} \mathrm{C}^{83} \quad(\mathbf{1}), \quad \mathrm{LH}^{84} \quad \mathrm{LLi}^{8}\left(\mathrm{OEt}_{2}\right)^{38} \quad(\mathbf{5}) \quad(\mathrm{L}=$ $\left.\left\{\mathrm{HC}(\mathrm{CMeNAr})_{2}\right\}, \operatorname{Ar}=2,6-i \mathrm{PrC}_{6} \mathrm{H}_{3}\right), \operatorname{ArNH}\left(\mathrm{CH}_{2}\right)_{3} \mathrm{NHAr}^{74 \mathrm{c}}$ and $\mathrm{MnCl}_{2}(\mathrm{THF})_{1.5}{ }^{85}$ were synthesized as described in the literature. Anhydrous $\mathrm{MnCl}_{2}$ was obtained by dehydration of $\mathrm{MnCl}_{2}\left(\mathrm{H}_{2} \mathrm{O}\right)_{4}{ }^{86}$ Other chemicals used in this work were purchased from Aldrich Chemical Co, ACROS, and Fluka Co and used without further purification. The NMR spectra of the manganese complexes are not available due to the paramagnetic property of manganese(II).

\subsection{Synthesis}

\subsubsection{Synthesis of $\left\{[\mathrm{C}(\mathrm{Me}) \mathrm{N}(\mathrm{iPr})]_{2} \mathrm{C}\right\}_{2} \mathrm{MnCl}_{2}(2)$}

THF (40 mL) was added to a mixture of $1(0.72 \mathrm{~g}, 4 \mathrm{mmol})$ and $\mathrm{MnCl}_{2}(\mathrm{THF})_{1.5}(0.47 \mathrm{~g}, 2$ mmol) at room temperature. The suspension was stirred for $13 \mathrm{~h}$. The solvent was concentrated to ca. $3 \mathrm{~mL}$ and the colorless precipitate was collected by filtration. 
2: Yield: 0.88 g (91 \%). Mp: $268-270{ }^{\circ} \mathrm{C} . \mathrm{C}_{22} \mathrm{H}_{40} \mathrm{Cl}_{2} \mathrm{MnN}_{4}$ (486.42): calcd. C 54.27, H 8.22, N, 11.51; found C 54.3, H 8.2, N 11.5. IR (Nujol mull, $\left.\mathrm{cm}^{-1}\right): \widetilde{v}=1629(\mathrm{~m}), 1552(\mathrm{w}), 1401$ (m), 1376 (s), 1360 (s), 1262 (w), 1218 (m), 1168 (w), 1136 (m), 1107 (w), 1070 (m), 1023 (w), $968(w), 931(w), 905(w), 885(w), 803(w), 751(\mathrm{~m}), 722(\mathrm{~m}), 674(\mathrm{w}), 544(\mathrm{~m}), 412$ (w).

\subsubsection{Synthesis of $\left\{[\mathrm{C}(\mathrm{Me}) \mathrm{N}(i \mathrm{Pr})]_{2} \mathrm{C}\right\}_{2} \mathrm{MnI}_{2}(3)$}

The procedure is the same as that described for 2 with $\mathrm{MnI}_{2}(0.62 \mathrm{~g}, 2 \mathrm{mmol})$ instead of the $\mathrm{MnCl}_{2}(\mathrm{THF})_{1.5}$.

3: Yield: 1.03 g (77 \%). Mp: 273 - $283{ }^{\circ} \mathrm{C} . \mathrm{C}_{22} \mathrm{H}_{40} \mathrm{I}_{2} \mathrm{MnN}_{4}$ (669.32): calcd. C 39.46, H 5.98, $\mathrm{N}$ 8.37; found C 39.5, H 6.0, N 8.3. IR (Nujol mull, $\mathrm{cm}^{-1}$ ): $\widetilde{v}=1629$ (m), 1552 (w), 1398 (m), 1377 (s), 1364 (s), 1291 (w), 1262 (w), 1219 (m), 1191 (w), 1168 (w), 1136 (m), 1109 (w), $1071(\mathrm{~m}), 1023(\mathrm{w}), 968(\mathrm{w}), 931(\mathrm{w}), 905(\mathrm{w}), 886(\mathrm{w}), 848(\mathrm{w}), 803(\mathrm{w}), 750(\mathrm{~m}), 722$ (m).

\subsubsection{Synthesis of $\left\{[\mathrm{C}(\mathrm{Me}) \mathrm{N}(i \mathrm{Pr})]_{2} \mathrm{C}\right\}_{2} \mathrm{Mn}(\mathrm{MeCOO})_{2}$ (4)}

THF (40 mL) was added to a mixture of $1(0.72 \mathrm{~g}, 4 \mathrm{mmol})$ and $\mathrm{Mn}(\mathrm{MeCOO})_{2}(0.34 \mathrm{~g}, 2$ mmol) at room temperature. A clear solution was obtained immediately and stirred for $6 \mathrm{~h}$. The solution was concentrated to ca. $5 \mathrm{~mL}$ and kept at $-26{ }^{\circ} \mathrm{C}$ for $3 \mathrm{~d}$ to give colorless crystals of 4 .

4: Yield: 0.86 g (81 \%). Mp: 156 - $158{ }^{\circ} \mathrm{C} . \mathrm{C}_{26} \mathrm{H}_{46} \mathrm{MnN}_{4} \mathrm{O}_{4}$ (532.96): calcd. C 58.54, $\mathrm{H}$ 8.63, $\mathrm{N}$ 10.51; found C 58.6, H 8.7, N 10.1. IR (Nujol mull, $\mathrm{cm}^{-1}$ ): $\tilde{v}=1750$ (w), 1695 (w), 1628 (s), 1599 (vs), 1573 (s), 1406 (s), 1323 (m), 1260 (m), 1238 (w), 1222 (m), 1195 (w), 1167 (w), $1138(\mathrm{~m}), 1112(\mathrm{~m}), 1073(\mathrm{w}), 1048(\mathrm{w}), 10231(\mathrm{w}), 917(\mathrm{w}), 908(\mathrm{w}), 888(\mathrm{w}), 804(\mathrm{~s})$, $751(\mathrm{~m}), 722(\mathrm{~m}), 658$ (s), $648(\mathrm{w}), 616(\mathrm{~m}), 544(\mathrm{~m}), 483(\mathrm{w}), 457(\mathrm{w}), 411(\mathrm{w})$. 


\subsubsection{Synthesis of LK (6)}

A suspension of $\mathrm{KH}(0.18 \mathrm{~g}, 4.5 \mathrm{mmol})$ and $\mathrm{LH}(1.67 \mathrm{~g}, 4 \mathrm{mmol})$ in diethyl ether $(50 \mathrm{~mL})$ was stirred at room temperature for $1 \mathrm{~d}$. After filtration, the light yellow filtrate was concentrated to ca. $5 \mathrm{~mL}$ and kept at $-26{ }^{\circ} \mathrm{C}$ for $24 \mathrm{~h}$ to afford a crystalline solid.

6: Yield: $1.59 \mathrm{~g}(87 \%) .{ }^{1} \mathrm{H}$ NMR and elemental analyses are consistent with those in the literature. ${ }^{39}$

\subsubsection{Synthesis of $\mathrm{LMn}(\mu-\mathrm{Cl})_{2} \operatorname{Li}\left(\mathrm{OEt}_{2}\right)_{2}(7)$}

$\operatorname{LLi}\left(\mathrm{OEt}_{2}\right)(5)(1.0 \mathrm{~g}, 2 \mathrm{mmol})$ in diethyl ether $(15 \mathrm{~mL})$ was added to a suspension of $\mathrm{MnCl}_{2}(0.25 \mathrm{~g}, 2 \mathrm{mmol})$ in diethyl ether $(40 \mathrm{~mL})$ at $-78{ }^{\circ} \mathrm{C}$. The mixture was warmed to room temperature and stirred for $14 \mathrm{~h}$. The resulting precipitate was removed by filtration. The solution was concentrated to a volume of $10 \mathrm{~mL}$. Yellow crystals of 7 were obtained at $26{ }^{\circ} \mathrm{C}$ after $2 \mathrm{~d}$.

7: Yield: $1.13 \mathrm{~g}(81 \%)$. Mp: $>270{ }^{\circ} \mathrm{C}$ (dec.). $\mathrm{C}_{37} \mathrm{H}_{61} \mathrm{Cl}_{2} \mathrm{LiMnN}_{2} \mathrm{O}_{2}$ (698.66): calcd. C 63.55, H 8.73, N 4.01; found C 63.1, H 8.5, N 4.5. EI-MS: $m / z$ (\%) 507 (100) [M-LiCl( $\left.\left(\mathrm{OEt}_{2}\right)_{2}\right]^{+}$. IR (Nujol mull, $\mathrm{cm}^{-1}$ ): $\tilde{v}=1624(\mathrm{w}), 1539$ (w), $1523(\mathrm{~m}), 1398(\mathrm{~m}), 1366(\mathrm{w}), 1316(\mathrm{~m}), 1262$ (m), $1231(\mathrm{w}), 1176(\mathrm{w}), 1099$ (m), 1056 (w), 1022 (m), 934 (w), 873 (w), $853(\mathrm{w}), 795(\mathrm{~m})$, $759(w), 722(w), 636(w), 600(w), 527(w), 452(w)$.

\subsubsection{Synthesis of $[\mathrm{LMn}(\mu-\mathrm{Cl})]_{2}(8)$}

LK (6) $(0.91 \mathrm{~g}, 2 \mathrm{mmol})$ in diethyl ether $(15 \mathrm{~mL})$ was added to a suspension of $\mathrm{MnCl}_{2}$ $(0.25 \mathrm{~g}, 2 \mathrm{mmol})$ in diethyl ether $(40 \mathrm{~mL})$ at $-78{ }^{\circ} \mathrm{C}$. The mixture was warmed to room temperature and stirred for $14 \mathrm{~h}$. The resulting precipitate was removed by filtration. The solution was concentrated to a volume of $10 \mathrm{~mL}$. Yellow crystals of $\mathbf{8}$ were obtained after 1 d at $-26^{\circ} \mathrm{C}$.

8: Yield: 0.88 g (87 \%). Mp: > $400{ }^{\circ} \mathrm{C} . \mathrm{C}_{58} \mathrm{H}_{82} \mathrm{Cl}_{2} \mathrm{Mn}_{2} \mathrm{~N}_{4}$ (1016.06): calcd. C 68.54, H 8.13, N 5.52; found C 68.8, H 8.2, N 5.2. EI-MS: $m / z(\%) 507$ (100) $[1 / 2 \mathrm{M}]^{+}$. IR (Nujol mull, $\mathrm{cm}^{-}$ 
$\left.{ }^{1}\right): \tilde{V}=1656(\mathrm{w}), 1623(\mathrm{w}), 1592(\mathrm{w}), 1553(\mathrm{w}), 1528(\mathrm{w}), 1326(\mathrm{w}), 1292(\mathrm{w}), 1261(\mathrm{~m})$, 1175 (m), 1098 (m), 1025 (m), 936 (w), 801 (m), 758 (w), 722 (w), $664(\mathrm{w}), 618(\mathrm{w}), 541$ (w), $466(\mathrm{w})$.

\subsubsection{Synthesis of $\mathrm{LMn}(\mu-\mathrm{Cl})_{2} \mathrm{Mn}(\mathrm{THF})_{2}(\mu-\mathrm{Cl})_{2} \mathrm{MnL}(9)$}

LK (6) $(0.91 \mathrm{~g}, 2 \mathrm{mmol})$ in THF (15 mL) was added to a suspension of $\mathrm{MnCl}_{2}(\mathrm{THF})_{1.5}$ $(0.70 \mathrm{~g}, 3 \mathrm{mmol})$ in $\mathrm{THF}(40 \mathrm{~mL})$ at $-78{ }^{\circ} \mathrm{C}$. The mixture was warmed to room temperature and stirred for $14 \mathrm{~h}$. The precipitate was removed by filtration. The solution was concentrated to ca. $10 \mathrm{~mL}$ and kept at $4{ }^{\circ} \mathrm{C}$ for $24 \mathrm{~h}$ to give yellow crystals. The crystals were collected by filtration and the mother liquor was concentrated to ca. $5 \mathrm{~mL}$ and kept at $26^{\circ} \mathrm{C}$ for $24 \mathrm{~h}$ to give additional crystals.

9: Yield: $1.28 \mathrm{~g}$ (81 \%). Mp: $>400{ }^{\circ} \mathrm{C} . \mathrm{C}_{66} \mathrm{H}_{98} \mathrm{Cl}_{4} \mathrm{Mn}_{3} \mathrm{~N}_{4} \mathrm{O}_{2}$ (1286.51): calcd. C 61.56, $\mathrm{H}$ 7.62, N 4.35; found C 61.6, H 7.5, N 4.2. EI-MS: $m / z$ (\%) 507 (100) [LMnCl] $]^{+}$IR (Nujol mull, $\left.\mathrm{cm}^{-1}\right): \tilde{v}=1525(\mathrm{~m}), 1400(\mathrm{w}), 1316(\mathrm{~s}), 1292(\mathrm{w}), 1263$ (s), 1230 (w), 1176 (w), 1100 (s), 1098 (m), 1075 (m), 1056 (m), 1022 (s), 934 (w), 852 (w), 794 (s), 758 (m), 721 (w), $636(\mathrm{w}), 527(\mathrm{w}), 468(\mathrm{w}), 452(\mathrm{w})$.

\subsubsection{Synthesis of $\left[\mathrm{LMnCl}_{2}\right]\left[\{\mathrm{C}(\mathrm{Me}) \mathrm{N}(\mathrm{iPr})\}_{2} \mathrm{CH}\right](10)$}

THF (40 mL) was added to a mixture of $\mathrm{MnCl}_{2}$ (THF) 1.5 (0.47 g, $\left.2 \mathrm{mmol}\right), \mathrm{LH}(0.83 \mathrm{~g}, 2$ $\mathrm{mmol})$ and $[\mathrm{C}(\mathrm{Me}) \mathrm{N}(i \mathrm{Pr})]_{2} \mathrm{C}(0.36 \mathrm{~g}, 2 \mathrm{mmol})$ at room temperature. The resulting suspension was stirred for $12 \mathrm{~h}$ and a clear yellow solution was obtained. The solution was concentrated to ca. $10 \mathrm{~mL}$ and kept at $4{ }^{\circ} \mathrm{C}$. Yellow crystals were obtained after $3 \mathrm{~d}$.

10: Yield: $1.23 \mathrm{~g}(85 \%)$. Mp: $>210{ }^{\circ} \mathrm{C}$ (dec.). $\mathrm{C}_{40} \mathrm{H}_{62} \mathrm{Cl}_{2} \mathrm{MnN}_{4}$ (724.78): calcd. C 66.23, $\mathrm{H}$ 8.55, N 7.73; found C 65.9, H 8.8, N 7.5. EI-MS: $m / z$ (\%) 723 (2) $[\mathrm{M}-\mathrm{H}]^{+}, 507$ (43) $[\mathrm{LMnCl}]^{+}, 202(100)\left[\mathrm{ArNCCH}_{3}\right]^{+}, 181(52)\left[\{\mathrm{C}(\mathrm{Me}) \mathrm{N}(i \mathrm{Pr})\}_{2} \mathrm{CH}\right]^{+} . \mathrm{IR}$ (Nujol mull, $\left.\mathrm{cm}^{-1}\right)$ : $\tilde{V}=3126(\mathrm{w}), 3058(\mathrm{w}), 1663(\mathrm{w}), 1628(\mathrm{w}), 1551(\mathrm{~m}), 1542(\mathrm{~m}), 1516(\mathrm{~m}), 1438(\mathrm{~s}), 1400$ (s), 1321 (s), 1263 (s), 1232 (m), 1193 (w), 1177 (m), 1143 (w), 1101 (s), 1056 (w), 1023 (s), $962(\mathrm{w}), 936(\mathrm{~m}), 868(\mathrm{w}), 849(\mathrm{w}), 799(\mathrm{~s}), 792(\mathrm{~s}), 764(\mathrm{~m}), 758(\mathrm{~m}), 721(\mathrm{w}), 652(\mathrm{w})$, $630(\mathrm{w})$. 


\subsubsection{Synthesis of $\mathrm{LMnCp}(\mathrm{THF})$ (11)}

CpNa (0.6 mL, 2.0 M in THF, $1.2 \mathrm{mmol})$ was added to a solution of $8(0.51 \mathrm{~g}, 0.5 \mathrm{mmol})$ in THF $(20 \mathrm{~mL})$ at $-78{ }^{\circ} \mathrm{C}$. The mixture was allowed to warm to room temperature and stirred for $14 \mathrm{~h}$. All volatiles were removed in vacuum and the residue was extracted with toluene $(15 \mathrm{~mL})$. The yellow solution was concentrated to ca. $10 \mathrm{~mL}$ and kept at room temperature for $2 \mathrm{~d}$ to give yellow crystals. The crystals were collected by filtration and the filtrate was concentrated and kept at $4{ }^{\circ} \mathrm{C}$ for $7 \mathrm{~d}$ to give additional crystals.

11: Total yield: $0.52 \mathrm{~g}(86 \%)$. Mp: 210 - $212{ }^{\circ} \mathrm{C} . \mathrm{C}_{38} \mathrm{H}_{54} \mathrm{MnN}_{2} \mathrm{O}$ (609.77): calcd. C 74.88, $\mathrm{H}$ 8.87, N 4.60; found C 74.5, H 8.8, N 4.6. EI-MS: $m / z$ (\%) 537 (100) [M] $]^{+}, 472$ (92) [LMn] $]^{+}$ IR (Nujol mull, cm ${ }^{-1}$ ): $\widetilde{v}=1653(\mathrm{w}), 1542$ (w), 1521 (m), 1401 (m), 1315 (m), 1262 (s), 1231 (w), 1172 (w), 1098 (s), 1056 (m), 1028 (s), 933 (w), 872 (w), 846 (w), 793 (s), 765 (w), $751(\mathrm{~m}), 721(\mathrm{~m}), 667(\mathrm{w}), 601(\mathrm{w}), 466(\mathrm{w})$.

\subsubsection{Synthesis of $[\mathrm{LMn}(\mu-\mathrm{Me})]_{2}(12)$}

MeLi $(1.5 \mathrm{~mL}, 1.6 \mathrm{M}$ in diethyl ether, $2.4 \mathrm{mmol})$ was added to a suspension of $\mathbf{8}(1.01 \mathrm{~g}, 1$ mmol) in toluene $(40 \mathrm{~mL})$ at $-78{ }^{\circ} \mathrm{C}$. The mixture was allowed to warm to room temperature and stirred for $14 \mathrm{~h}$. All the volatiles were removed in vacuum and the residue was extracted with hexane $(2 \times 20 \mathrm{~mL})$. The yellow solution was concentrated to ca. $20 \mathrm{~mL}$ and kept at room temperature for $24 \mathrm{~h}$ to give yellow solids of $\mathbf{1 2}$ containing a small amount of $\mathbf{8}$. Recrystallization of the solid from pentane was repeated two times and crystals were obtained. The crystals were collected by filtration and the filtrate was concentrated and kept at $4{ }^{\circ} \mathrm{C}$ for one week to give additional crystals.

12: Total yield: $0.51 \mathrm{~g}(52 \%)$. Mp: 190 - $192{ }^{\circ} \mathrm{C} . \mathrm{C}_{60} \mathrm{H}_{88} \mathrm{Mn}_{2} \mathrm{~N}_{4}$ (975.22): calcd. C 73.83, $\mathrm{H}$ 9.02, N 5.74; found C 73.3, H 8.8, N 5.6. EI-MS: $m / z$ (\%) 487 (6) [LMnMe] $]^{+}, 472$ (100) $[\mathrm{LMn}]^{+}$. IR (Nujol mull, $\mathrm{cm}^{-1}$ ): $\tilde{v}=1658$ (w), 1624 (w), 1589 (w), 1552 (w), 1525 (w), 1314 (w), 1261 (m), $1174(\mathrm{w}), 1098$ (w), 1040 (w), $1021(\mathrm{w}), 936$ (w), 798 (m), 759 (w), 721 (w), $662(w), 563(w)$. 


\subsubsection{Synthesis of LMnPh (13)}

The precedure is the same as that described for $\mathbf{1 2}$ with $\mathrm{PhLi}(2.4 \mathrm{~mL}, 1.0 \mathrm{M}$ in diethyl and cyclohexane, $2.4 \mathrm{mmol}$ ) instead of MeLi.

13: Yield: $0.71 \mathrm{~g}(65 \%)$. Mp: 230 - $232{ }^{\circ} \mathrm{C} . \mathrm{C}_{35} \mathrm{H}_{46} \mathrm{MnN}_{2}$ (549.68): calcd. C 76.41, H 8.37,

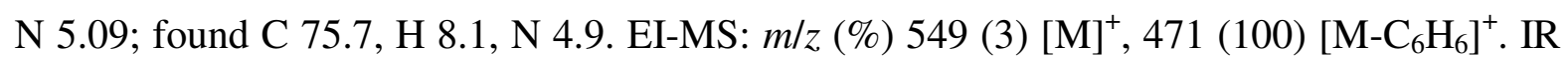
(Nujol mull, $\mathrm{cm}^{-1}$ ): $\tilde{v}=1660$ (w), 1640 (w), 1625 (w), 1590 (w), 1553 (w), 1531 (w), 1312 (w), 1261 (m), 1170 (w), 1095 (m), 1021 (m), 937 (w), 873 (w), 799 (m), 761 (w), 724 (w), $674(w), 643(w), 613(w), 604(w), 583(w), 525(w), 463(w)$.

\subsubsection{Synthesis of $\mathrm{LMnC}_{3} \mathrm{H}_{5}$ (THF) (14)}

$\mathrm{C}_{3} \mathrm{H}_{5} \mathrm{MgCl}(1.1 \mathrm{~mL}, 2.0 \mathrm{M}$ in THF, $2.2 \mathrm{mmol})$ was added to a suspension of 9 (0.64 g, 0.5 $\mathrm{mmol})$ in toluene $(20 \mathrm{~mL})$ at $-78{ }^{\circ} \mathrm{C}$. The mixture was allowed to warm to room temperature and stirred for $14 \mathrm{~h}$. All volatiles were removed in vacuum and the residue was extracted with hexane $(2 \times 15 \mathrm{~mL})$. The yellow solution was concentrated to ca. $15 \mathrm{~mL}$ and kept at 4 ${ }^{\circ} \mathrm{C}$ for $48 \mathrm{~h}$ to give yellow crystals. The crystals were collected by filtration and the filtrate was concentrated and kept at $-26^{\circ} \mathrm{C}$ for $7 \mathrm{~d}$ to give additional crystals of $\mathbf{1 4}$.

14: Total yield: $0.25 \mathrm{~g}$ (43 \%). Mp: $>173{ }^{\circ} \mathrm{C}$ (dec.). $\mathrm{C}_{36} \mathrm{H}_{54} \mathrm{MnN}_{2} \mathrm{O}$ (585.75): calcd. C 73.75, H 9.22, N 4.78; found C 74.1, H 9.0, N 4.6. EI-MS: $m / z$ (\%) 513 (8) [M-THF] ${ }^{+}, 472$ (100) $[\mathrm{LMn}]^{+}$. IR (Nujol mull, $\mathrm{cm}^{-1}$ ): $\tilde{v}=1653$ (w), 1521 (m), 1401 (m), 1317 (m), 1262 (s), 1175 (w), 1098 (s), 1021 (m), 933 (w), 847 (w), 794 (m), 760 (w), 738 (w), 722 (m), 693 (w), 663 (w).

\subsubsection{Synthesis of $[\mathrm{LMn}(\mu-\mathrm{CCPh})]_{2}(15)$}

PhCCLi (2.2 mL, 1.0 M in THF, $2.2 \mathrm{mmol})$ was added to a suspension of 9 (0.64 g, 0.5 $\mathrm{mmol})$ in toluene $(20 \mathrm{~mL})$ at $-78^{\circ} \mathrm{C}$. The mixture was allowed to warm to room temperature and stirred for $14 \mathrm{~h}$. All volatiles were removed in vacuum and the residue was extracted with hexane $(2 \times 15 \mathrm{~mL})$. The yellow solution was concentrated to ca. $15 \mathrm{~mL}$ and kept at 4 ${ }^{\circ} \mathrm{C}$ for $48 \mathrm{~h}$ to give yellow crystals. The crystals were collected by filtration and the filtrate was concentrated and kept at $-26^{\circ} \mathrm{C}$ for $4 \mathrm{~d}$ to give additional crystals of $\mathbf{1 5}$. 
15: Total yield: $0.32 \mathrm{~g}(56 \%) . \mathrm{Mp}:>170{ }^{\circ} \mathrm{C}$ (dec.). $\mathrm{C}_{74} \mathrm{H}_{92} \mathrm{Mn}_{2} \mathrm{~N}_{4}$ (1147.4): calcd. C 77.39, H 8.02, N 4.88; found C 77.1, H 8.5, N 4.7. EI-MS: $m / z$ (\%) 1146 (1) [M] $]^{+}, 573$ (40) $[1 / 2 \mathrm{M}]^{+}, 471(100)[\mathrm{LMn}-\mathrm{H}]^{+}$. IR (Nujol mull, $\left.\mathrm{cm}^{-1}\right): \tilde{v}=2034(\mathrm{w}), 1524(\mathrm{~m}), 1317(\mathrm{~m})$, 1260 (s), 1177 (w), 1098 (s), 1056 (m), 1021 (s), $931(\mathrm{w}), 865$ (w), $756(\mathrm{w}), 721(\mathrm{~m})$.

\subsubsection{Synthesis of $[\mathrm{LMn}(\mu-\mathrm{MeCOO})]_{2}(16)$}

LK (6) (0.91 g, $2 \mathrm{mmol})$ in THF (10 mL) was added to a suspension of $\mathrm{Mn}(\mathrm{MeCOO})_{2}$ $(0.35 \mathrm{~g}, 2 \mathrm{mmol})$ in $\mathrm{THF}(30 \mathrm{~mL})$ at $-78{ }^{\circ} \mathrm{C}$. The mixture was warmed to room temperature and stirred for $12 \mathrm{~h}$. The resulting precipitate was removed by filtration. The solution was concentrated to a volume of $5 \mathrm{~mL}$. Yellow crystals were obtained at $-26{ }^{\circ} \mathrm{C}$ after $7 \mathrm{~d}$.

16: Yield: $0.80 \mathrm{~g}(75 \%)$. Mp: $>330{ }^{\circ} \mathrm{C}$ (dec.). $\mathrm{C}_{62} \mathrm{H}_{88} \mathrm{Mn}_{2} \mathrm{~N}_{4} \mathrm{O}_{4}$ (1063.24): calcd. C 70.00, $\mathrm{H}$ 8.28, N 5.27; found C 69.7, H 8.2, N 5.0. EI-MS: $m / z$ (\%) 531 (100) [1/2M] $]^{+}$. IR (Nujol mull, $\left.\mathrm{cm}^{-1}\right): \widetilde{v}=1602(\mathrm{~s}), 1544(\mathrm{~m}), 1519(\mathrm{~m}), 1437(\mathrm{~s}), 1380(\mathrm{~m}), 1317(\mathrm{~m}), 1262(\mathrm{w}), 1177$ (w), $1099(w), 1021(w), 933(w), 851(w), 793(w), 759(w), 643(w)$.

\subsubsection{Synthesis of LMnI(THF) (17)}

A solution of $\mathbf{6}(0.91 \mathrm{~g}, 2 \mathrm{mmol})$ in THF $(10 \mathrm{~mL})$ was added to a suspension of $\mathrm{MnI}_{2}(0.62$ $\mathrm{g}, 2 \mathrm{mmol})$ in THF $(35 \mathrm{~mL})$ at $-78{ }^{\circ} \mathrm{C}$. The mixture was allowed to warm to room temperature and stirred for $14 \mathrm{~h}$. The precipitate was removed by filtration. The filtrate was concentrated to ca. $5 \mathrm{~mL}$ and kept at $-26^{\circ} \mathrm{C}$ for $24 \mathrm{~h}$ to give yellow crystals of $\mathbf{1 7}$.

17: Yield: $1.17 \mathrm{~g}(87 \%)$. Mp: 379 - $381{ }^{\circ} \mathrm{C} . \mathrm{C}_{33} \mathrm{H}_{49} \mathrm{IMnN}_{2} \mathrm{O}$ (670.84): calcd. C 59.03, $\mathrm{H}$ 7.30, N 4.17; found C 59.0, H 7.2, N 4.2. EI-MS: $m / z$ (\%) 599 (100) [LMnI] $]^{+}$IR (Nujol mull, $\left.\mathrm{cm}^{-1}\right): \tilde{v}=1624(\mathrm{w}), 1552(\mathrm{w}), 1520.62(\mathrm{~m}), 1314(\mathrm{~m}), 1262(\mathrm{~m}), 1174(\mathrm{w}), 1100(\mathrm{w})$, $1024(\mathrm{~m}), 935(\mathrm{w}), 870(\mathrm{w}), 852(\mathrm{w}), 794(\mathrm{~m}), 757(\mathrm{w}), 721(\mathrm{w}), 600(\mathrm{w}), 524(\mathrm{w}), 468(\mathrm{w})$.

\subsubsection{Synthesis of $[\operatorname{LMn}(\mu-\mathrm{I})]_{2}(18)$}

A solution of $17(1.34 \mathrm{~g}, 2 \mathrm{mmol})$ in toluene $(40 \mathrm{~mL})$ was refluxed for $0.5 \mathrm{~h}$. All volatiles were removed in vacuum and bright yellow microcrystals of $\mathbf{1 8}$ were obtained. 
18: Yield: $1.15 \mathrm{~g}(96 \%)$. Mp: $271-273{ }^{\circ} \mathrm{C}$ (dec.). $\mathrm{C}_{58} \mathrm{H}_{82} \mathrm{I}_{2} \mathrm{Mn}_{2} \mathrm{~N}_{4}$ (1197.68): calcd. C 58.11, H 6.84, N 4.67; found C 58.3, H 6.9, N 4.9. EI-MS: $m / z$ (\%) 599 (100) [LMnI] ${ }^{+}$IR (Nujol mull, $\left.\mathrm{cm}^{-1}\right): \widetilde{v}=1657(\mathrm{w}), 1625(\mathrm{w}), 1552(\mathrm{w}), 1262(\mathrm{~m}), 1097(\mathrm{~m}), 1023(\mathrm{~m}), 875(\mathrm{w}), 800$ (m), $722(\mathrm{w}), 659(\mathrm{w}), 536(\mathrm{w}), 468(\mathrm{w})$.

\subsubsection{Synthesis of $\operatorname{LMnI}\left\{\mathrm{C}[\mathrm{N}(\mathrm{iPr}) \mathrm{C}(\mathrm{Me})]_{2}\right\}(19)$}

A solution of $\mathrm{C}[\mathrm{N}(i \mathrm{Pr}) \mathrm{C}(\mathrm{Me})]_{2}(0.18 \mathrm{~g}, 1 \mathrm{mmol})$ in THF $(10 \mathrm{~mL})$ was added to a THF $(20$ $\mathrm{mL})$ solution of $17(0.67 \mathrm{~g}, 1 \mathrm{mmol})$ at room temperature. The resulting solution was stirred for $1 \mathrm{~h}$. After removal of all volatiles in vacuum a yellow solid was obtained.

19: Yield: $0.76 \mathrm{~g}\left(98 \%\right.$ ). Mp: $>271{ }^{\circ} \mathrm{C}$ (dec.). $\mathrm{C}_{40} \mathrm{H}_{61} \mathrm{IMnN}_{4}$ (778.8): calcd. C 61.63, H 7.83, N 7.19; found C 61.8, H 8.0, N 7.2. EI-MS: m/z (\%) 599 (100) [LMnI] ${ }^{+}$. IR (Nujol mull, cm ${ }^{-}$ $\left.{ }^{1}\right): \tilde{v}=1625(\mathrm{~m}), 1552(\mathrm{~s}), 1505(\mathrm{~m}), 1318(\mathrm{~m}), 1261$ (s), $1232(\mathrm{w}), 1218(\mathrm{w}), 1190(\mathrm{w})$, 1171 (m), 1105 (m), 1071 (w), 1020 (m), 936 (w), 929 (w), 793 (s), 763 (m), 758 (m), 722 $(\mathrm{m})$.

\subsubsection{Synthesis of LMnNHAr $\left\{\mathrm{C}[\mathrm{N}(i \operatorname{Pr}) \mathrm{C}(\mathrm{Me})]_{2}\right\}(20)$}

Route a: A solution of $\mathbf{1 9}(0.78 \mathrm{~g}, 1 \mathrm{mmol})$ in THF (20 mL) was added to a suspension of $\mathrm{Na} / \mathrm{K}$ alloy (Na $0.01 \mathrm{~g}, 0.5 \mathrm{mmol} ; \mathrm{K} 0.04 \mathrm{~g}, 1 \mathrm{mmol})$ in THF $(10 \mathrm{~mL})$. The mixture was stirred for $6 \mathrm{~d}$ at room temperature. All volatiles were removed in vacuum and the residue was extracted with $n$-hexane $(10 \mathrm{~mL})$. Yellow crystals of $\mathbf{2 0}$ were obtained after cooling for one week at $4{ }^{\circ} \mathrm{C}$. The crystals were collected by filtration and the mother liquor was concentrated to ca. $4 \mathrm{~mL}$ and kept at $4{ }^{\circ} \mathrm{C}$ for $3 \mathrm{~d}$ to give yellow crystals.

20: Total yield: 0.19 g (23\%). Mp: 170 - $172{ }^{\circ} \mathrm{C} . \mathrm{C}_{52} \mathrm{H}_{79} \mathrm{MnN}_{5}$ (829.14): calcd. C 75.26, H 9.53, N 8.44; found C 74.8, H 9.9, N 8.8. EI-MS: $m / z(\%) 472$ (100) [LMn] ${ }^{+}, 648$ (52) [LMnNHAr] $^{+}$. IR (Nujol mull, $\mathrm{cm}^{-1}$ ): $\tilde{v}=3173(\mathrm{w}), 1633$ (w), 1588 (w), 1543 (w), 1512 (m), 1420 (s), 1406 (m), 1316 (m), 1261 (m), 1169 (m), 1102 (w), 1019 (w), 929 (w), 886 (w), $841(w), 794(m), 758(w), 737(m), 722(m), 600(w), 565(w), 543(w)$. 
Route b: A THF (10 mL) solution of LiNHAr (0.18 g, $1 \mathrm{mmol})$ was added to a THF (20 $\mathrm{mL})$ solution of $19(0.78 \mathrm{~g}, 1 \mathrm{mmol})$ at $-78{ }^{\circ} \mathrm{C}$. The mixture was allowed to warm to room temperature and stirred for $14 \mathrm{~h}$. After removal of all volatiles in vacuum the residue was extracted with diethyl ether $(10 \mathrm{~mL})$. After filtration, the yellow filtrate was concentrated to ca. $5 \mathrm{~mL}$ and stored at $-26{ }^{\circ} \mathrm{C}$ for $3 \mathrm{~d}$ to give yellow crystals. Yield: $0.63 \mathrm{~g}$ (76 \%). The spectroscopical characterization of the compound corresponds to that of the compound prepared by route $a$.

\subsubsection{Synthesis of $[\mathrm{LMn}]_{2}(21)$}

At room temperature, a suspension of $18(0.60 \mathrm{~g}, 0.5 \mathrm{mmol})$ in toluene $(30 \mathrm{~mL})$ was added to a $\mathrm{Na} / \mathrm{K}$ alloy ( $\mathrm{Na} 0.01 \mathrm{~g}, 0.5 \mathrm{mmol} ; \mathrm{K} 0.04 \mathrm{~g}, 1 \mathrm{mmol}$ ). The mixture was stirred at room temperature for $4 \mathrm{~d}$ and a red solution was obtained. After filtration, the solution was concentrated to ca. $10 \mathrm{~mL}$. Dark red crystals were obtained at $4{ }^{\circ} \mathrm{C}$ after $7 \mathrm{~d}$.

21: Yield: 0.07 g (15\%). Mp: 154 - $156{ }^{\circ} \mathrm{C} . \mathrm{C}_{58} \mathrm{H}_{82} \mathrm{Mn}_{2} \mathrm{~N}_{4}$ (945.16): calcd. C 73.65, H 8.68, N 5.93; found C 73.6, H 8.7, N 5.7. EI-MS: $m / z$ (\%) $944(5)[\mathrm{M}]^{+}, 472(100)[1 / 2 \mathrm{M}]^{+}$. IR (Nujol mull, $\mathrm{cm}^{-1}$ ): $\tilde{v}=1698(\mathrm{w}), 1654$ (w), 1624 (w), 1577 (w), 1555 (w), 1261 (s), 1092 (s), $1019(\mathrm{~s}), 937(\mathrm{w}), 866(\mathrm{w}), 799(\mathrm{~s}), 762(\mathrm{w}), 722(\mathrm{w}), 667(\mathrm{w}), 614(\mathrm{w}), 568(\mathrm{w})$.

\subsubsection{Synthesis of $[\operatorname{LMn}(\mu-\mathrm{O})]_{2}(22)$}

$\mathrm{KMnO}_{4}(0.5 \mathrm{~g}, 3.2 \mathrm{mmol})$ was added to a solution of $21(0.2 \mathrm{~g}, 0.2 \mathrm{mmol})$ in toluene (20 $\mathrm{mL}$ ) at room temperature. The mixture was stirred at room temperature for $2 \mathrm{~d}$. Unreacted $\mathrm{KMnO}_{4}$ was removed by filtration. The solvent was removed and the residue was extracted with diethyl ether. Red crystals were obtained at $4{ }^{\circ} \mathrm{C}$ after $4 \mathrm{~d}$.

22: Yield: 0.14 g (72\%). Mp: 213 - $215{ }^{\circ} \mathrm{C} . \mathrm{C}_{58} \mathrm{H}_{82} \mathrm{Mn}_{2} \mathrm{~N}_{4} \mathrm{O}_{2}$ (977.16): calcd. C 71.23, H 5.94, N 5.73; found C 70.9, H 5.7, N 5.5. EI-MS: $m / z$ (\%) 976 (100) [M] ${ }^{+}$. IR (Nujol mull, $\left.\mathrm{cm}^{-1}\right): \tilde{v}=1659(\mathrm{w}), 1623(\mathrm{w}), 1592(\mathrm{w}), 1552(\mathrm{w}), 1528(\mathrm{w}), 1261$ (s), 1094 (s), 1025 (s), $936(\mathrm{w}), 919(\mathrm{w}), 842(\mathrm{w}), 801(\mathrm{~s}), 761(\mathrm{w}), 720(\mathrm{w}), 699(\mathrm{w}), 668(\mathrm{w}), 607(\mathrm{w}), 514(\mathrm{w})$, $467(\mathrm{w})$. 


\subsubsection{Synthesis of $\left[\operatorname{ArN}\left(\mathrm{CH}_{2}\right)_{3} \mathrm{NAr}\right]\left[\mathrm{Li}\left(\mathrm{OEt}_{2}\right)\right]_{2}(23)$}

To a diethyl ether $(35 \mathrm{~mL})$ solution of $\operatorname{ArNH}\left(\mathrm{CH}_{2}\right)_{3} \mathrm{NHAr}(1.58 \mathrm{~g}, 4 \mathrm{mmol}) \mathrm{MeLi}(5.5$ $\mathrm{mL}, 1.6 \mathrm{M}$ in diethyl ether, $8.8 \mathrm{mmol}$ ) was added at $-78{ }^{\circ} \mathrm{C}$. The mixture was warmed to room temperature and stirred for additional $14 \mathrm{~h}$. The precipitate was removed by filtration. The filtrate was concentrated to ca. $10 \mathrm{~mL}$ and kept at $-26{ }^{\circ} \mathrm{C}$ for $24 \mathrm{~h}$ to give colorless crystals. The crystals were collected by filtration and the mother liquor was concentrated to ca. $4 \mathrm{~mL}$ and kept at $-26^{\circ} \mathrm{C}$ for $24 \mathrm{~h}$ to give colorless crystals.

23: Total yield: $2.04 \mathrm{~g}$ (92 \%). Mp: $>110{ }^{\circ} \mathrm{C}$ (dec.). $\mathrm{C}_{35} \mathrm{H}_{60} \mathrm{Li}_{2} \mathrm{~N}_{2} \mathrm{O}_{2}$ (554.75): calcd. C 75.78, $\mathrm{H}$ 10.90, N 5.05; found C 75.9, $\mathrm{H} 11.0, \mathrm{~N} 4.9 .{ }^{1} \mathrm{H}$ NMR $\left(250 \mathrm{MHz}, \mathrm{C}_{6} \mathrm{D}_{6}, \mathrm{ppm}\right): \delta=6.91-$ $7.22\left(\mathrm{~m}, \mathrm{C}_{6} \mathrm{H}_{3}, 6 \mathrm{H}\right), 3.38$ (sept, $\mathrm{CHMe}_{2}, 4 \mathrm{H}$ ), 3.12 (t, $\mathrm{MeCH} \mathrm{H}_{2} \mathrm{O}, 8 \mathrm{H}$ ), 3.00-3.25 (m, $\left.\mathrm{NCH}_{2} \mathrm{CH}_{2}, 4 \mathrm{H}\right), 1.79$ (b, $\left.\mathrm{NCH}_{2} \mathrm{CH}_{2}, 2 \mathrm{H}\right) 1.34$ (d, Me $\left.2 \mathrm{CH}, 12 \mathrm{H}\right), 1.23\left(\mathrm{~d}, \mathrm{Me}_{2} \mathrm{CH}, 12 \mathrm{H}\right)$ 0.95 (t, $\left.\mathrm{MeCH}_{2} \mathrm{O}, 12 \mathrm{H}\right) .{ }^{7} \mathrm{Li} \mathrm{NMR}\left(300 \mathrm{MHz}, \mathrm{C}_{6} \mathrm{D}_{6}, \mathrm{ppm}\right): 1.90$.

\subsubsection{Synthesis of $\mathrm{Mn}_{2}\left[\mathrm{ArN}\left(\mathrm{CH}_{2}\right)_{3} \mathrm{NAr}\right]_{2}(24)$}

A solution of $23(1.1 \mathrm{~g}, 2 \mathrm{mmol})$ in diethyl ether $(10 \mathrm{~mL})$ was added to a suspension of $\mathrm{MnCl}_{2}(0.25 \mathrm{~g}, 2 \mathrm{mmol})$ in diethyl ether $(30 \mathrm{~mL})$ at $-78{ }^{\circ} \mathrm{C}$. The mixture was warmed to room temperature and stirred for additional $14 \mathrm{~h}$. The precipitate was removed by filtration and extracted by dichloromethane $(10 \mathrm{~mL})$. A yellow-green solid was obtained by removing the solvent in vacuum. The mother liquor was concentrated to ca. $10 \mathrm{~mL}$ and yellow-green crystals were obtained at room temperature after $5 \mathrm{~d}$.

24: Total yield: $0.64 \mathrm{~g}$ (72 \%). Mp: $>220{ }^{\circ} \mathrm{C}$ (dec.). $\mathrm{C}_{54} \mathrm{H}_{80} \mathrm{Mn}_{2} \mathrm{~N}_{4}$ (895.10): calcd. C 72.39, H 8.94, N 6.26; found C 72.2, H 8.9, N 6.2. EI-MS: $m / z(\%)=894$ (49) [M] $]^{+}, 705$ (100) [M$\left.\mathrm{CH}_{2} \mathrm{NAr}\right]^{+}, 447(68)[1 / 2 \mathrm{M}]^{+} . \mathrm{IR}\left(\right.$ Nujol mull, $\mathrm{cm}^{-1}$ ): $\tilde{v}=1426(\mathrm{w}), 1308(\mathrm{w}), 1260(\mathrm{w})$, 1243 (w), $1169(w), 1092$ (w), 1073 (w), 1041(w), 1019 (w), 857 (w), $800(w), 786(w), 722$ (w). 


\section{Handling and Disposal of Solvents and Residual Wastes}

- The recovered solvents were distilled or condensed into cold traps under vacuum, collected in halogen-free or halogen-containing solvent containers, and stored for disposal.

- Deuterated solvents for NMR were classified into halogen-free and halogen-containing solvents and were disposed as heavy metal wastes and halogen-containing wastes, respectively.

- The heavy metal residues were dissolved in nitric acid and were stored after neutralization in the containers for heavy metal wastes.

- Drying agents such as $\mathrm{KOH}, \mathrm{CaCl}_{2}$, and $\mathrm{P}_{4} \mathrm{O}_{10}$ were hydrolyzed and deposited as acid or base wastes.

- Whenever possible, sodium metal used for drying solvents was collected for recycling. ${ }^{87,88}$ The non-reusable sodium metal was carefully hydrolyzed in cold ethanol and poured into the base-bath used for cleaning glassware.

- Ethanol and acetone used for solid $\mathrm{CO}_{2}$ cold-baths were subsequently used for cleaning glassware.

- The acid-bath used for cleaning glassware was neutralized with $\mathrm{Na}_{2} \mathrm{CO}_{3}$ and the resulting $\mathrm{NaCl}$ solution was washed-off into the water drainage.

- The residue of the base bath used for glassware cleaning was poured into the container for base wastes.

Amount of various types of disposable wastes generated during this work:

Metal containing wastes $10 \mathrm{~L}$

Halogen-containing solvent wastes $12 \mathrm{~L}$

Halogen-free solvent wastes $35 \mathrm{~L}$

Acid wastes $12 \mathrm{~L}$

Base wastes $20 \mathrm{~L}$ 


\section{Crystal Data and Refinement Details}

\section{Compound}

Empirical formula

Formula weight

Temperature

Wavelength

Crystal system

Space group

Unit cell dimensions

Volume

Z

Density (calculated)

Absorption coefficient

$F(000)$

Crystal size

$\theta$ range for data collection

Index ranges

Reflections collected

Independent reflections

Refinement method

Data / restrains / parameters

Goodness-of-fit on $F^{2}$

Final $R$ indices $[I>2 \sigma(I)]$

$R$ (all data)

Largest diff. peak and hole

\section{2}

$\mathrm{C}_{22} \mathrm{H}_{40} \mathrm{Cl}_{2} \mathrm{MnN}_{4}$

486.42

200(2) K

$0.71073 \AA$

monoclinic

$P 2(1) / n$

$a=11.2852(17) \AA$

$b=14.867(3) \AA \quad \beta=90.24(2)^{\circ}$

$c=15.321(3) \AA$

2570.6(9) $\AA^{3}$

4

1.257 $\mathrm{Mgm}^{-3}$

$0.736 \mathrm{~mm}^{-1}$

1036

$1.00 \times 0.30 \times 0.20 \mathrm{~mm}^{3}$

$3.54-22.53^{\circ}$

$-12 \leq \mathrm{h} \leq 12,-16 \leq \mathrm{k} \leq 10,-12 \leq 1 \leq 16$

3570

$3348(R($ int $)=0.0671)$

Full-matrix least-squares on $F^{2}$

3348 / 0 / 274

1.081

$R 1=0.0460, w R 2=0.1150$

$R 1=0.0544, w R 2=0.1233$

0.673 and $-0.854 \mathrm{e} \cdot \AA^{-3}$ 


\section{Compound}

Empirical formula

Formula weight

Temperature

Wavelength

Crystal system

Space group

Unit cell dimensions

Volume

Z

Density (calculated)

Absorption coefficient

$F(000)$

Crystal size

$\theta$ range for data collection

Index ranges

Reflections collected

Independent reflections

Refinement method

Data / restrains / parameters

Goodness-of-fit on $F^{2}$

Final $R$ indices $[I>2 \sigma(I)]$

$R$ (all data)

Largest diff. peak and hole

\section{3}

$\mathrm{C}_{22} \mathrm{H}_{40} \mathrm{I}_{2} \mathrm{MnN}_{4}$

669.32

200(2) K

0.71073

monoclinic

$P 2(1) / n$

$a=11.2771(13) \AA$

$b=16.054(3) \AA \quad \beta=90.399(14)^{\circ}$

$c=15.705(3) \AA$

2843.1(8) $\AA^{3}$

4

$1.564 \mathrm{Mgm}^{-3}$

$2.650 \mathrm{~mm}^{-1}$

1324

$0.80 \times 0.60 \times 0.30 \mathrm{~mm}^{3}$

$3.61-25.01^{\circ}$

$-13 \leq \mathrm{h} \leq 13,-3 \leq \mathrm{k} \leq 19,-18 \leq 1 \leq 18$

6010

$4994(R($ int $)=0.0660)$

Full-matrix least-squares on $F^{2}$

4994 / 0 / 274

1.065

$R 1=0.0411, w R 2=0.1077$

$R 1=0.0440, w R 2=0.1111$

1.161 and $-1.433 \mathrm{e} \cdot \AA^{-3}$ 


\section{Compound}

Empirical formula

Formula weight

Temperature

Wavelength

Crystal system

Space group

Unit cell dimensions

Volume

Z

Density (calculated)

Absorption coefficient

$F(000)$

Crystal size

$\theta$ range for data collection

Index ranges

Reflections collected

Independent reflections

Refinement method

Data / restrains / parameters

Goodness-of-fit on $F^{2}$

Final $R$ indices $[I>2 \sigma(I)]$

$R$ (all data)

Largest diff. peak and hole
4 incl. THF

$\mathrm{C}_{30} \mathrm{H}_{54} \mathrm{MnN}_{4} \mathrm{O}_{5}$

605.71

203(2) K

0.71073

monoclinic

$C 2 / c$

$a=12.970(2) \AA$

$b=14.374(3) \AA \quad \beta=106.070(10)^{\circ}$

$c=19.322(2) \AA$

3461.5(10) $\AA^{3}$

4

$1.162 \mathrm{Mgm}^{-3}$

$0.421 \mathrm{~mm}^{-1}$

1308

$0.90 \times 0.70 \times 0.70 \mathrm{~mm}^{3}$

$3.54-24.94^{\circ}$

$-15 \leq \mathrm{h} \leq 15,-10 \leq \mathrm{k} \leq 17,-18 \leq 1 \leq 22$

3231

$3028(R($ int $)=0.0717)$

Full-matrix least-squares on $F^{2}$

3028 / 0 / 174

1.015

$R 1=0.0595, w R 2=0.1597$

$R 1=0.0670, w R 2=0.1701$

0.762 and $-0.834 \mathrm{e} \cdot \AA^{-3}$ 


\section{Compound}

Empirical formula

Formula weight

Temperature

Wavelength

Crystal system

Space group

Unit cell dimensions

Volume

$\mathrm{Z}$

Density (calculated)

Absorption coefficient

$F(000)$

Crystal size

$\theta$ range for data collection

Index ranges

Reflections collected

Independent reflections

Refinement method

Data / restrains / parameters

Goodness-of-fit on $F^{2}$

Final $R$ indices $[I>2 \sigma(I)]$

$R$ (all data)

Largest diff. peak and hole
7

$\mathrm{C}_{37} \mathrm{H}_{61} \mathrm{Cl}_{2} \mathrm{LiMnN}_{2} \mathrm{O}_{2}$

698.66

153(2) K

$0.71073 \AA$

monoclinic

$P 2_{1} / n$

$a=12.053(2) \AA$

$b=21.327(4) \AA \quad \beta=100.11(3)^{\circ}$

$c=15.706(3) \AA$

3974.3(14) $\AA^{3}$

4

$1.168 \mathrm{Mgm}^{-3}$

$0.498 \mathrm{~mm}^{-1}$

1500

$0.90 \times 0.60 \times 0.30 \mathrm{~mm}^{3}$

$3.57-25.05^{\circ}$

$-14 \leq \mathrm{h} \leq 14,-8 \leq \mathrm{k} \leq 25,-18 \leq 1 \leq 18$

10312

$6998(R($ int $)=0.0574)$

Full-matrix least-squares on $F^{2}$

6998 / 0 / 420

1.026

$R 1=0.0505, w R 2=0.1213$

$R 1=0.0636, w R 2=0.1322$

0.562 and $-0.634 \mathrm{e} \cdot \AA^{-3}$ 


\section{Compound}

Empirical formula

Formula weight

Temperature

Wavelength

Crystal system

Space group

Unit cell dimensions

Volume

Z

Density (calculated)

Absorption coefficient

$F(000)$

Crystal size

$\theta$ range for data collection

Index ranges

Reflections collected

Independent reflections

Refinement method

Data / restrains / parameters

Goodness-of-fit on $F^{2}$

Final $R$ indices $[I>2 \sigma(I)]$

$R$ (all data)

Largest diff. peak and hole
8

$\mathrm{C}_{58} \mathrm{H}_{82} \mathrm{Cl}_{2} \mathrm{Mn}_{2} \mathrm{~N}_{4}$

1006.06

200(2) K

$0.71073 \AA$

monoclinic

$C 2 / c$

$a=22.921(5) \AA$

$b=14.8779(15) \AA \quad \beta=90.884(12)^{\circ}$

$c=16.291(2) \AA$

5555.1(15) $\AA^{3}$

4

1.215 $\mathrm{Mgm}^{-3}$

$0.590 \mathrm{~mm}^{-1}$

2168

$0.60 \times 0.40 \times 0.40 \mathrm{~mm}^{3}$

$3.51-24.98^{\circ}$

$-27 \leq \mathrm{h} \leq 27,-17 \leq \mathrm{k} \leq 17,-6 \leq 1 \leq 19$

7144

$4872(R($ int $)=0.0307)$

Full-matrix least-squares on $F^{2}$

4872 / 0 / 308

1.024

$R 1=0.0626, w R 2=0.1648$

$R 1=0.0821, w R 2=0.1817$

0.400 and $-1.366 \mathrm{e} \cdot \AA^{-3}$ 


\section{Compound}

Empirical formula

Formula weight

Temperature

Wavelength

Crystal system

Space group

Unit cell dimensions

Volume

Z

Density (calculated)

Absorption coefficient

$F(000)$

Crystal size

$\theta$ range for data collection

Index ranges

Reflections collected

Independent reflections

Refinement method

Data / restrains / parameters

Goodness-of-fit on $F^{2}$

Final $R$ indices $[I>2 \sigma(I)]$

$R$ (all data)

Largest diff. peak and hole
9 incl. 4 THF

$\mathrm{C}_{82} \mathrm{H}_{130} \mathrm{Cl}_{4} \mathrm{Mn}_{3} \mathrm{~N}_{4} \mathrm{O}_{6}$

1574.52

133(2) K

$0.71073 \AA$

monoclinic

$C 2 / m$

$a=17.238(3) \AA$

$b=18.411(3) \AA \quad \beta=113.947(13)^{\circ}$

$c=14.729(2) \AA$

4272.3(12) $\AA^{3}$

2

$1.224 \mathrm{Mgm}^{-3}$

$0.612 \mathrm{~mm}^{-1}$

1682

$0.30 \times 0.20 \times 0.20 \mathrm{~mm}^{3}$

$1.51-24.80^{\circ}$

$-20 \leq \mathrm{h} \leq 20,-21 \leq \mathrm{k} \leq 21,-17 \leq 1 \leq 17$

22430

$3785(R($ int $)=0.1105)$

Full-matrix least-squares on $F^{2}$

3785 / 0 / 214

1.028

$R 1=0.0777, w R 2=0.2045$

$R 1=0.1171, w R 2=0.2295$

1.021 and $-0.646 \mathrm{e} \cdot \AA^{-3}$ 


\section{Compound}

Empirical formula

Formula weight

Temperature

Wavelength

Crystal system

Space group

Unit cell dimensions

Volume

Z

Density (calculated)

Absorption coefficient

$F(000)$

Crystal size

$\theta$ range for data collection

Index ranges

Reflections collected

Independent reflections

Refinement method

Data / restrains / parameters

Goodness-of-fit on $F^{2}$

Final $R$ indices $[I>2 \sigma(I)]$

$R$ (all data)

Largest diff. peak and hole
10

$\mathrm{C}_{40} \mathrm{H}_{62} \mathrm{Cl}_{2} \mathrm{MnN}_{4}$

724.78

150(2) K

$0.71073 \AA$

orthorhombic

$P 2{ }_{1} 2_{1} 2_{1}$

$a=11.218(4) \AA$

$b=12.606(10) \AA$

$c=28.93(2) \AA$

4090(1) $\AA^{3}$

4

$1.177 \mathrm{Mgm}^{-3}$

$0.484 \mathrm{~mm}^{-1}$

1556

$0.60 \times 0.60 \times 0.50 \mathrm{~mm}^{3}$

$3.53-22.49^{\circ}$

$0 \leq \mathrm{h} \leq 12,-4 \leq \mathrm{k} \leq 13,-31 \leq 1 \leq 31$

3116

$2999(R($ int $)=0.0745)$

Full-matrix least-squares on $F^{2}$

2999 / 0 / 449

1.089

$R 1=0.0445, w R 2=0.1009$

$R 1=0.0653, w R 2=0.1136$

0.533 and $-0.505 \mathrm{e} \cdot \AA^{-3}$ 


\section{Compound}

Empirical formula

Formula weight

Temperature

Wavelength

Crystal system

Space group

Unit cell dimensions

Volume

Z

Density (calculated)

Absorption coefficient

$F(000)$

Crystal size

$\theta$ range for data collection

Index ranges

Reflections collected

Independent reflections

Refinement method

Data / restrains / parameters

Goodness-of-fit on $F^{2}$

Final $R$ indices $[I>2 \sigma(I)]$

$R$ (all data)

Largest diff. peak and hole
11

$\mathrm{C}_{38} \mathrm{H}_{54} \mathrm{MnN}_{2} \mathrm{O}$

609.77

133(2) K

$0.71073 \AA$

orthorhombic

$P 22_{1} 2_{1}$

$a=10.007(2) \AA$

$b=16.985(3) \AA$

$c=20.081(4) \AA$

3413.3(12) $\AA^{3}$

4

$1.187 \mathrm{Mgm}^{-3}$

$0.417 \mathrm{~mm}^{-1}$

1316

$0.30 \times 0.30 \times 0.30 \mathrm{~mm}^{3}$

$1.57-24.72^{\circ}$

$-11 \leq \mathrm{h} \leq 11,-19 \leq \mathrm{k} \leq 19,-23 \leq 1 \leq$

23

36246

$5798(R($ int $)=0.0371)$

Full-matrix least-squares on $F^{2}$

5798 / 0 / 389

1.064

$R 1=0.0255, w R 2=0.0617$

$R 1=0.0280, w R 2=0.0626$

0.305 and $-0.291 \mathrm{e} \cdot \AA^{-3}$ 


\section{Compound}

Empirical formula

Formula weight

Temperature

Wavelength

Crystal system

Space group

Unit cell dimensions

Volume

Z

Density (calculated)

Absorption coefficient

$F(000)$

Crystal size

$\theta$ range for data collection

Index ranges

Reflections collected

Independent reflections

Refinement method

Data / restrains / parameters

Goodness-of-fit on $F^{2}$

Final $R$ indices $[I>2 \sigma(I)]$

$R$ (all data)

Largest diff. peak and hole
12

$\mathrm{C}_{30} \mathrm{H}_{44} \mathrm{MnN}_{2}$

487.61

133(2) K

$0.71073 \AA$

monoclinic

$C 2 / c$

$a=22.612(5) \AA$

$b=14.880(3) \AA \quad \beta=90.05(3)^{\circ}$

$c=16.481(3) \AA$

5545.2(19) $\AA^{3}$

8

$1.168 \mathrm{Mgm}^{-3}$

$0.495 \mathrm{~mm}^{-1}$

2104

$0.30 \times 0.20 \times 0.10 \mathrm{~mm}^{3}$

$1.64-24.71^{\circ}$

$-26 \leq \mathrm{h} \leq 26,-17 \leq \mathrm{k} \leq 17,-19 \leq 1 \leq 19$

20857

$4662(R($ int $)=0.0360)$

Full-matrix least-squares on $F^{2}$

4662 / 0 / 320

1.068

$R 1=0.0327, w R 2=0.0736$

$R 1=0.0413, w R 2=0.0772$

0.257 and $-0.260 \mathrm{e} \cdot \AA^{-3}$ 


\section{Compound}

Empirical formula

Formula weight

Temperature

Wavelength

Crystal system

Space group

Unit cell dimensions

Volume

$\mathrm{Z}$

Density (calculated)

Absorption coefficient

$F(000)$

Crystal size

$\theta$ range for data collection

Index ranges

Reflections collected

Independent reflections

Refinement method

Data / restrains / parameters

Goodness-of-fit on $F^{2}$

Final $R$ indices $[I>2 \sigma(I)]$

$R$ (all data)

Largest diff. peak and hole
13

$\mathrm{C}_{35} \mathrm{H}_{46} \mathrm{MnN}_{2}$

549.68

133(2) K

$0.71073 \AA$

orthorhombic

\section{Pnma}

$a=16.6103(13) \AA$

$b=20.943(2) \AA$

$c=9.2785(13) \AA$

3227.8(6) $\AA^{3}$

4

$1.131 \mathrm{Mgm}^{-3}$

$0.433 \mathrm{~mm}^{-1}$

1180

$0.30 \times 0.20 \times 0.20 \mathrm{~mm}^{3}$

$1.94-22.99^{\circ}$

$-16 \leq \mathrm{h} \leq 16,-23 \leq \mathrm{k} \leq 22,-8 \leq 1 \leq 10$

8044

$2191(R($ int $)=0.0751)$

Full-matrix least-squares on $F^{2}$

$2191 / 0 / 183$

1.029

$R 1=0.0514, w R 2=0.1188$

$R 1=0.0758, w R 2=0.1296$

0.199 and $-0.408 \mathrm{e} \cdot \AA^{-3}$ 


\section{Compound}

Empirical formula

Formula weight

Temperature

Wavelength

Crystal system

Space group

Unit cell dimensions

Volume

Z

Density (calculated)

Absorption coefficient

$F(000)$

Crystal size

$\theta$ range for data collection

Index ranges

Reflections collected

Independent reflections

Refinement method

Data / restrains / parameters

Goodness-of-fit on $F^{2}$

Final $R$ indices $[I>2 \sigma(I)]$

$R$ (all data)

Largest diff. peak and hole
14

$\mathrm{C}_{36} \mathrm{H}_{54} \mathrm{MnN}_{2} \mathrm{O}$

585.75

133(2) K

$0.71073 \AA$

triclinic

$P-1$

$a=9.034(2) \AA \quad \alpha=87.22(2)^{\circ}$

$b=12.177(4) \AA \quad \beta=77.909(16)^{\circ}$

$c=15.952(3) \AA \quad \gamma=89.24(2)^{\circ}$

1713.9(7) $\AA^{3}$

2

$1.135 \mathrm{Mgm}^{-3}$

$0.413 \mathrm{~mm}^{-1}$

634

$0.30 \times 0.30 \times 0.30 \mathrm{~mm}^{3}$

$1.67-24.72^{\circ}$

$-10 \leq \mathrm{h} \leq 10,-13 \leq \mathrm{k} \leq 14,-18 \leq 1 \leq 18$

18432

$5810(R($ int $)=0.0417)$

Full-matrix least-squares on $F^{2}$

$5810 / 0 / 379$

1.036

$R 1=0.0341, w R 2=0.0772$

$R 1=0.0487, w R 2=0.0814$

0.380 and $-0.220 \mathrm{e} \cdot \AA^{-3}$ 


\section{Compound}

Empirical formula

Formula weight

Temperature

Wavelength

Crystal system

Space group

Unit cell dimensions

Volume

Z

Density (calculated)

Absorption coefficient

$F(000)$

Crystal size

$\theta$ range for data collection

Index ranges

Reflections collected

Independent reflections

Refinement method

Data / restrains / parameters

Goodness-of-fit on $F^{2}$

Final $R$ indices $[I>2 \sigma(I)]$

$R$ (all data)

Largest diff. peak and hole
15

$\mathrm{C}_{74} \mathrm{H}_{92} \mathrm{Mn}_{2} \mathrm{~N}_{4}$

1147.40

100(2) K

$1.54178 \AA$

monoclinic

$P 2(1) / n$

$a=14.010(1) \AA$

$b=13.257(1) \AA \quad \beta=98.59(1)^{\circ}$

$c=17.697(1) \AA$

3250(1) $\AA^{3}$

2

$1.172 \mathrm{Mgm}^{-3}$

$3.483 \mathrm{~mm}^{-1}$

1228

$0.30 \times 0.20 \times 0.10 \mathrm{~mm}^{3}$

$3.76-59.46^{\circ}$

$-15 \leq \mathrm{h} \leq 15,-13 \leq \mathrm{k} \leq 14,-19 \leq 1 \leq 19$

15989

$4637(R($ int $)=0.0458)$

Full-matrix least-squares on $F^{2}$

4637 / 0 / 375

1.049

$R 1=0.0356, w R 2=0.0803$

$R 1=0.0503, w R 2=0.0860$

0.441 and $-0.251 \mathrm{e} \cdot \AA^{-3}$ 


\section{Compound}

Empirical formula

Formula weight

Temperature

Wavelength

Crystal system

Space group

Unit cell dimensions

Volume

Z

Density (calculated)

Absorption coefficient

$F(000)$

Crystal size

$\theta$ range for data collection

Index ranges

Reflections collected

Independent reflections

Refinement method

Data / restrains / parameters

Goodness-of-fit on $F^{2}$

Final $R$ indices $[I>2 \sigma(I)]$

$R$ (all data)

Largest diff. peak and hole
16

$\mathrm{C}_{62} \mathrm{H}_{88} \mathrm{Mn}_{2} \mathrm{~N}_{4} \mathrm{O}_{4}$

1063.24

203(2) K

$0.71073 \AA$

monoclinic

$P 2{ }_{1} / c$

$a=17.32(3) \AA$

$b=15.210(17) \AA \quad \beta=101.94(6)^{\circ}$

$c=23.30(3) \AA$

6010(2) $\AA^{3}$

4

1.176 $\mathrm{Mgm}^{-3}$

$0.467 \mathrm{~mm}^{-1}$

2280

$0.70 \times 0.40 \times 0.30 \mathrm{~mm}^{3}$

$3.53-22.50^{\circ}$

$-18 \leq \mathrm{h} \leq 14,0 \leq \mathrm{k} \leq 16,0 \leq 1 \leq 25$

7382

$7382(R($ int $)=0.0000)$

Full-matrix least-squares on $F^{2}$

7382 / 0 / 671

1.013

$R 1=0.0815, w R 2=0.1843$

$R 1=0.1403, w R 2=0.2315$

0.579 and $-0.721 \mathrm{e} \cdot \AA^{-3}$ 


\section{Compound}

Empirical formula

Formula weight

Temperature

Wavelength

Crystal system

Space group

Unit cell dimensions

Volume

Z

Density (calculated)

Absorption coefficient

$F(000)$

Crystal size

$\theta$ range for data collection

Index ranges

Reflections collected

Independent reflections

Refinement method

Data / restrains / parameters

Goodness-of-fit on $F^{2}$

Final $R$ indices $[I>2 \sigma(I)]$

$R$ (all data)

Largest diff. peak and hole
17

$\mathrm{C}_{33} \mathrm{H}_{49} \mathrm{IMnN}_{2} \mathrm{O}$

671.58

203(2) K

$0.71073 \AA$

monoclinic

$P 2(1) / c$

$a=16.752(2) \AA$

$b=20.290(6) \AA \quad \beta=91.317(14)^{\circ}$

$c=19.620(3) \AA$

6670(1) $\AA^{3}$

8

$1.336 \mathrm{Mgm}^{-3}$

$1.348 \mathrm{~mm}^{-1}$

2776

$0.70 \times 0.50 \times 0.30 \mathrm{~mm}^{3}$

$3.52-25.03^{\circ}$

$-19 \leq \mathrm{h} \leq 19,-4 \leq \mathrm{k} \leq 24,-23 \leq 1 \leq 23$

14274

$11722(R($ int $)=0.0616)$

Full-matrix least-squares on $F^{2}$

11722 / 0 / 705

1.053

$R 1=0.0534, w R 2=0.1296$

$R 1=0.0714, w R 2=0.1457$

0.971 and $-1.279 \mathrm{e} \cdot \AA^{-3}$ 


\section{Compound}

Empirical formula

Formula weight

Temperature

Wavelength

Crystal system

Space group

Unit cell dimensions

Volume

Z

Density (calculated)

Absorption coefficient

$F(000)$

Crystal size

$\theta$ range for data collection

Index ranges

Reflections collected

Independent reflections

Refinement method

Data / restrains / parameters

Goodness-of-fit on $F^{2}$

Final $R$ indices $[I>2 \sigma(I)]$

$R$ (all data)

Largest diff. peak and hole
18 incl. toluene

$\mathrm{C}_{65} \mathrm{H}_{90} \mathrm{I}_{2} \mathrm{Mn}_{2} \mathrm{~N}_{4}$

1291.22

203(2) K

$0.71073 \AA$

monoclinic

$C 2 / m$

$a=19.188(3) \AA$

$b=21.000(4) \AA \quad \beta=100.053(8)^{\circ}$

$c=16.5839(13) \AA$

$6580.0(16) \AA^{3}$

4

$1.396 \mathrm{Mgm}^{-3}$

$1.366 \mathrm{~mm}^{-1}$

2856

$0.50 \times 0.50 \times 0.40 \mathrm{~mm}^{3}$

$3.57-25.00^{\circ}$

$-22 \leq \mathrm{h} \leq 22,-5 \leq \mathrm{k} \leq 24,-19 \leq 1 \leq 19$

7832

$5952(R($ int $)=0.0425)$

Full-matrix least-squares on $F^{2}$

5952 / 0 / 374

1.018

$R 1=0.0349, w R 2=0.0900$

$R 1=0.0388, w R 2=0.0936$

0.977 and $-0.788 \mathrm{e} \cdot \AA^{-3}$ 


\section{Compound}

Empirical formula

Formula weight

Temperature

Wavelength

Crystal system

Space group

Unit cell dimensions

Volume

Z

Density (calculated)

Absorption coefficient

$F(000)$

Crystal size

$\theta$ range for data collection

Index ranges

Reflections collected

Independent reflections

Refinement method

Data / restrains / parameters

Goodness-of-fit on $F^{2}$

Final $R$ indices $[I>2 \sigma(I)]$

$R$ (all data)

Largest diff. peak and hole
20

$\mathrm{C}_{52} \mathrm{H}_{79} \mathrm{MnN}_{5}$

829.14

133(2) K

$0.71073 \AA$

monoclinic

$P 2(1) / c$

$a=11.694(2) \AA$

$b=19.388(4) \AA \quad \beta=102.59(3)^{\circ}$

$c=22.168(4) \AA$

4905.3(17) $\AA^{3}$

4

$1.123 \mathrm{Mgm}^{-3}$

$0.307 \mathrm{~mm}^{-1}$

1804

unmeasured

$1.78-24.72^{\circ}$

$-13 \leq \mathrm{h} \leq 13,-22 \leq \mathrm{k} \leq 22,-24 \leq 1 \leq 26$

34511

$8269(R($ int $)=0.0717)$

Full-matrix least-squares on $F^{2}$

8269 / 0 / 543

0.932

$R 1=0.0422, w R 2=0.0983$

$R 1=0.0616, w R 2=0.1044$

0.431 and $-0.469 \mathrm{e} \cdot \AA^{-3}$ 


\section{Compound}

Empirical formula

Formula weight

Temperature

Wavelength

Crystal system

Space group

Unit cell dimensions

Volume

Z

Density (calculated)

Absorption coefficient

$F(000)$

Crystal size

$\theta$ range for data collection

Index ranges

Reflections collected

Independent reflections

Refinement method

Data / restrains / parameters

Goodness-of-fit on $F^{2}$

Final $R$ indices $[I>2 \sigma(I)]$

$R$ (all data)

Largest diff. peak and hole
21

$\mathrm{C}_{58} \mathrm{H}_{82} \mathrm{Mn}_{2} \mathrm{~N}_{4}$

945.16

133(2) K

$0.71073 \AA$

monoclinic

$P 2(1) / c$

$a=14.4602(9) \AA$

$b=14.2263(6) \AA \quad \beta=94.999(6)^{\circ}$

$c=26.795(2) \AA$

5491.1(6) $\AA^{3}$

4

$1.143 \mathrm{Mgm}^{-3}$

$0.498 \mathrm{~mm}^{-1}$

2032

unmeasured

$1.62-24.81^{\circ}$

$-17 \leq \mathrm{h} \leq 16,-16 \leq \mathrm{k} \leq 16,-30 \leq 1 \leq 31$

38085

$9401(R($ int $)=0.1276)$

Full-matrix least-squares on $F^{2}$

9401 / 0 / 597

0.953

$R 1=0.0414, w R 2=0.0781$

$R 1=0.0716, w R 2=0.0825$

0.496 and $-0.567 \mathrm{e} \cdot \AA^{-3}$ 


\section{Compound}

Empirical formula

Formula weight

Temperature

Wavelength

Crystal system

Space group

Unit cell dimensions

Volume

Z

Density (calculated)

Absorption coefficient

$F(000)$

Crystal size

$\theta$ range for data collection

Index ranges

Reflections collected

Independent reflections

Refinement method

Data / restrains / parameters

Goodness-of-fit on $F^{2}$

Final $R$ indices $[I>2 \sigma(I)]$

$R$ (all data)

Largest diff. peak and hole
22

$\mathrm{C}_{58} \mathrm{H}_{82} \mathrm{Mn}_{2} \mathrm{~N}_{4} \mathrm{O}_{2}$

977.16

133(2) K

$0.71073 \AA$

monoclinic

$C 2 / c$

$a=15.4921(12) \AA$

$b=16.3958(9) \AA \quad \beta=90.802(6)^{\circ}$

$c=21.3688(17) \AA$

5427.3(7) $\AA^{3}$

4

$1.196 \mathrm{Mgm}^{-3}$

$0.509 \mathrm{~mm}^{-1}$

2096

unmeasured

$1.81-24.77^{\circ}$

$-18 \leq \mathrm{h} \leq 16,-19 \leq \mathrm{k} \leq 19,-25 \leq 1 \leq 25$

18243

$4641(R($ int $)=0.0637)$

Full-matrix least-squares on $F^{2}$

4641 / 0 / 308

1.024

$R 1=0.0421, w R 2=0.0873$

$R 1=0.0664, w R 2=0.0962$

0.325 and $-0.257 \mathrm{e} \cdot \AA^{-3}$ 


\section{Compound}

Empirical formula

Formula weight

Temperature

Wavelength

Crystal system

Space group

Unit cell dimensions

Volume

Z

Density (calculated)

Absorption coefficient

$F(000)$

Crystal size

$\theta$ range for data collection

Index ranges

Reflections collected

Independent reflections

Refinement method

Data / restrains / parameters

Goodness-of-fit on $F^{2}$

Final $R$ indices $[I>2 \sigma(I)]$

$R$ (all data)

Largest diff. peak and hole
23

$\mathrm{C}_{35} \mathrm{H}_{60} \mathrm{Li}_{2} \mathrm{~N}_{2} \mathrm{O}_{2}$

554.73

200(2) K

$0.71073 \AA$

monoclinic

$P 2(1) / n$

$a=11.224(2) \AA$

$b=9.6466(19) \AA \quad \beta=92.19(3)^{\circ}$

$c=32.070(6) \AA$

3469.7(12) $\AA^{3}$

4

$1.062 \mathrm{Mgm}^{-3}$

$0.063 \mathrm{~mm}^{-1}$

1224

$1.00 \times 0.70 \times 0.60 \mathrm{~mm}^{3}$

$3.60-22.53^{\circ}$

$-12 \leq \mathrm{h} \leq 12,-10 \leq \mathrm{k} \leq 10,-34 \leq 1 \leq 34$

7629

$4515(R($ int $)=0.0710)$

Full-matrix least-squares on $F^{2}$

4515 / 0 / 393

1.115

$R 1=0.0979, w R 2=0.2922$

$R 1=0.1357, w R 2=0.3219$

0.527 and $-0.427 \mathrm{e} \cdot \AA^{-3}$ 


\section{Compound}

Empirical formula

Formula weight

Temperature

Wavelength

Crystal system

Space group

Unit cell dimensions

Volume

Z

Density (calculated)

Absorption coefficient

$F(000)$

Crystal size

$\theta$ range for data collection

Index ranges

Reflections collected

Independent reflections

Refinement method

Data / restrains / parameters

Goodness-of-fit on $F^{2}$

Final $R$ indices $[I>2 \sigma(I)]$

$R$ (all data)

Largest diff. peak and hole
24

$\mathrm{C}_{54} \mathrm{H}_{80} \mathrm{Mn}_{2} \mathrm{~N}_{4}$

895.10

203(2) K

$0.71073 \AA$

triclinic

$P-1$

$a=11.545(9) \AA$

$b=13.642(10) \AA \quad \beta=94.01(3)^{\circ}$

$c=18.014(15) \AA$

2490(1) $\AA^{3}$

2

$1.192 \mathrm{Mgm}^{-3}$

$0.545 \mathrm{~mm}^{-1}$

964

$1.00 \times 0.50 \times 0.30 \mathrm{~mm}^{3}$

$3.54-25.04^{\circ}$

$-13 \leq \mathrm{h} \leq 13,-16 \leq \mathrm{k} \leq 15,-19 \leq 1 \leq 21$

11007

$8774(R($ int $)=0.0616)$

Full-matrix least-squares on $F^{2}$

8774 / 0 / 557

1.023

$R 1=0.0461, w R 2=0.1150$

$R 1=0.601, w R 2=0.1258$

0.533 and $-0.638 \mathrm{e} \cdot \AA^{-3}$ 


\section{References}

1. (a) P. M. Treichel, in Comprehensive Organometallic Chemistry, Eds: G. Wilkinson, F. G. A. Stone, E. W. Abel; Elsevier: Oxford, UK, 1982; Vol. 4, Chapter 29. (b) S. G. Davies, Organotransition Metal Chemistry: Application to Organic Synthesis; Pergamon Press: Elmsford, New York, 1982. (c) G. Cahiez, A. Martin, T. Delacroix, Tetrahedron Lett. 1999, 40, 6407. (d) C. Boucley, G. Cahiez, S. Carini, V. Cerè, M. Comes-Franchini, P. Knochel, S. Pollicino, A. Ricci, J. Organomet. Chem. 2001, 624, 223.

2. D. C. Weatherburn, S. Mandal, S. Mukhopadhyay, S. Bhaduri, L. F. Lindoy, in Comprehensive Coordination Chemistry II, Eds: E. C. Constable, J. R. Dilworth, Elsevier: Oxford, UK, 2004; Vol. 5.

3. W. Adam, J. Jekö, A. Lévai, Z. Majer, C. Nemes, T. Patonay, L. Párkányi, P. Sebök Tetrahedron: Asymmetry 1996, 7, 2437.

4. (a) D. Bourissou, O. Guerret, F. P. Gabbaï, G. Bertrand, Chem. Rev. 2000, 100, 39. (b) L. Jafarpour, S. P. Nolan, Adv. Organomet. Chem. 2000, 46, 181. (c) W. A. Herrmann, T. Weskamp, V. P. W. Böhm, Adv. Organomet. Chem. 2002, 48, 1.

5. A. J. Arduengo, III, R. L. Harlow, M. Kline, J. Am. Chem. Soc. 1991, 113, 361.

6. A. J. Arduengo, III, H. V. R. Dias, F. Davidson, R. L. Harlow, J. Organomet. Chem. 1993, 462, 13.

7. M. Albrecht, J. R. Miecznikowski, A. Samuel, J. W. Faller, R. H. Crabtree, Organometallics 2002, 21, 3596.

8. V. César, S. Bellemin-Laponnaz, L. H. Gade, Organometallics 2002, 21, 5204.

9. J. Louie, R. H. Grubbs, J. Chem. Soc., Chem. Commun. 2000, 1479.

10. (a) K. H. Dötz, H. Fischer, P. Hoffmann, F. R. Kreissl, U. Schubert, K. Weiss, Transition Metal Carbene Complexes VCH: Weinheim, 1983. (b) N. M. Kostić, R. F. Fenske, J. Am. Chem. Soc. 1982, 104, 3879. (c) N. Lugan, C. Kelley, M. R. Terry, G. L. Geoffroy, A. L. Rheingold, J. Am. Chem. Soc. 1990, 112, 3220. (d) T. R. Hoye, G. M. Rehberg, Organometallics 1990, 9, 3014.

11. M. F. Lappert, P. L. Pye, J. Chem. Soc., Dalton Trans. 1977, 2172.

12. A. Wacker, H. Pritzkow, W. Siebert, Eur. J. Inorg. Chem. 1998, 843.

13. R. A. Bartlett, M. M. Olmstead, P. P. Power, S. C. Shoner, Organometallics 1988, 7, 1801. 
14. J. G. Donkervoort, J. L. Vicario, J. T. B. H. Jastrzebski, R. A. Gossage, G. Chiez, G. Van Koten, J. Organomet. Chem. 1998, 558, 61.

15. Selected samples: (a) G. Cahiez, A. Masuda, D. Bernard, J. F. Normant, Tetrahedron Lett. 1976, 17, 3155. (b) G. Cahiez, B. Figadere, Tetrahedron Lett. 1986, 27, 4445. (c) G. Cahiez, M. Alami, Tetrahedron 1989, 45, 4163.

16. (a) U. Riese, B. Neumüller, N. Faza, W. Massa, K. Dehnicke, Z. Anorg. Allg. Chem. 1997, 623, 351. (b) H.-J. Mai, B. Neumüller, K. Dehnicke, Z. Naturforsch. 1996, 51b, 433.

17. D. M. Roundhill, Photochemistry and Photophysics of Metal Complexes, Plenum Press, New York, 1994.

18. R. Bianchi, G. Gervasio, D. Marabello, Inorg. Chem. 2000, 39, 2360.

19. (a) P. L. Holland, T. R. Cundari, L. L. Perez, N. A. Eckert, R. J. Lachicotte, J. Am. Chem. Soc. 2002, 124, 14416. (b) J. M. Smith, R. J. Lachicotte, K. A. Pittard, T. R. Cundari, G. Lukat-Rodgers, K. R. Rodger, P. L. Holland, J. Am. Chem. Soc. 2001, 123, 9222.

20. (a) A. Panda, M. Stender, R. J. Wright, M. M. Olmstead, P. Klavins, P. P. Power, Inorg. Chem. 2002, 41, 3909. (b) J. Chai, H. Zhu, H. Fan, H. W. Roesky, J. Magull, Organometallics 2004, 23, 1177. (c) J. J. Ellison, P. P. Power, S. C. Shoner, J. Am. Chem. Soc. 1989, 111, 8044.

21. (a) C. W. Hoganson, G. T. Babcock, Science 1997, 277, 1953. (b) H. Sakiyama, A. Sugawara, M. Sakamoto, K. Unoura, K. Inoue, M. Yamasaki, Inorg. Chim. Acta 2000, 310, 163. (c) J. Stubbe, W. A. van der Donk, Chem. Rev. 1998, 98, 705.

22. G. C. Dismukes, Chem. Rev. 1996, 96, 2909.

23. H. Sakiyama, A. Sugawara, M. Sakamoto, K. Unoura, K. Inoue, M. Yamasaki, Inorg. Chim. Acta 2000, 310, 163.

24. I. Romero, L. Dubois, M.-N. Collomb, A. Deronzier, J.-M. Latour, J. Pécaut, Inorg. Chem. 2002, 41, 1795.

25. W. A. Herrmann, K. Öfele, M. Elison, F. E. Kühn, P. W. Roesky, J. Organomet. Chem. 1994, 480, C7.

26. N. Hebendanz, F. H. Köhler, G. Müller, Inorg. Chem. 1984, 23, 3043.

27. B. Beagley, J. C. Briggs, A. Hosseiny, W. E. Hill, T. J. King, C. A. McAuliffe, K. Minten, J. Chem. Soc., Chem. Commun. 1984, 305.

28. W. A. Herrmann, F. C. Munck, G. R. J. Artus, O. Runte, R. Anwander, Organometallics, 1997, 16, 682. 
29. B. Albela, M. Corbella, J. Ribas, I. Castro, J. Sletten, H. Stoeckli-Evans, Inorg. Chem. 1998, 37,788 .

30. L. Dubois, D.-F. Xiang, X.-S. Tan, J. Pécaut, P. Jones, S. Baudron, L. Le Pape, J.-M. Latour, C. Baffert, S. Chardon-Noblat, M.-N. Collomb, A. Deronzier, Inorg. Chem. 2003, 42, 750 and references cited therein.

31. W. K. Dean, G. L. Simon, P. M. Treichel, L. F. Dahl, J. Organomet. Chem. 1973, 50, 193.

32. R. M. Wood, D. M. Stucker, L. M. Jones, W. B. Lynch, S. K. Misra, J. H. Freed, Inorg. Chem. 1999, 38, 5384 and references cited therein.

33. R. D. Dowsing, J. F. Gibson, D. M. L. Goodgame, M. Goodgame, P. J. Hayward, J. Chem. Soc., Dalton Trans. 1969, 1242.

34. R. D. Dowsing, J. F. Gibson, M. Goodgame, P. J. Hayward, J. Chem. Soc., Dalton Trans. 1970, 1133.

35. L. Bourget-Merle, M. F. Lappert, J. R. Severn, Chem. Rev. 2002, 102, 3031.

36. C. Cui, H. W. Roesky, H.-G. Schmidt, M. Noltemeyer, H. Hao, F. Cimpoesu, Angew. Chem. 2000, 112, 4444; Angew. Chem. Int. Ed. 2000, 39, 4274.

37. (a) G. Bai, Y. Peng, H. W. Roesky, J. Li, H.-G. Schmidt, M. Noltemeyer, Angew. Chem. 2003, 115, 1164; Angew. Chem. Int. Ed. 2003, 42, 1132. (b) G. Bai, H. W. Roesky, J. Li, M. Noltemeyer, H.-G. Schmidt, Angew. Chem. 2003, 115, 5660; Angew. Chem. Int. Ed. 2003, 42, 5502.

38. Y. Ding, H. W. Roesky, M. Noltemeyer, H.-G. Schmidt, P. P. Power, Organometallics 2001, 20, 1190 .

39. W. Clegg, E. K. Cope, A. J. Edwards, F. S. Mair, Inorg. Chem. 1998, 37, 2317.

40. (a) J. Prust, K. Most, I. Müller, A. Stasch, H. W. Roesky, I. Usón, Eur. J. Inorg. Chem. 2001, 1613. (b) J. M. Smith, R. J. Lachicotte, P. L. Holland, J. Chem. Soc., Chem. Commun. 2001, 1542.

41. J. Chai, H. Zhu, K. Most, H. W. Roesky, D. Vidovic, H.-G. Schmidt, M. Noltemeyer, Eur. J. Inorg. Chem. 2003, 4332.

42. S. Filipponi, J. N. Jones, J. A. Johnson, A. H. Cowley, F. Grepioni, D. Braga, Chem. Commun. 2003, 2716.

43. F. H. Köhler, N. Hebendanz, G. Müller, U. Thewalt, B. Kanellakopulos, R. Klenze, Organometallics 1987, 6, 115.

44. M. Tamura, J. Kochi, J. Organomet. Chem. 1971, 29, 111. 
45. J. Heck, W. Massa, P. Wenig, Angew. Chem. 1984, 96, 699; Angew. Chem. Int. Ed. Engl. 1984, 23, 722 .

46. R. A. Andersen, E. Carmona-Guzman, J. F. Gibson, G. Wilkinson, J. Chem. Soc., Dalton Trans. 1976, 2204.

47. L. E. Manzer, L. J. Guggenberger, J. Organomet. Chem. 1977, 139, C34.

48. J. I. Davies, C. G. Howard, A. C. Skapski, G. Wilkinson, J. Chem. Soc., Chem. Commun. 1982, 1077.

49. R. J. Morris, G. S. Girolami, Organometallics 1989, 8, 1478.

50. S. Gambarotta, C. Floriani, A. Chiesi-Villa, C. Guastini, J. Chem. Soc., Chem. Commun. 1983, 1128.

51. (a) N. H. Buttrus, C. Eaborn, P. B. Hitchcock, J. D. Smith, A. C. Sullivan, J. Chem. Soc., Chem. Commun. 1985, 1380. (b) R. A. Andersen, A. Haaland, K. Rypdal, H. V. Volden, J. Chem. Soc., Chem. Commun. 1985, 1807.

52. R. Ahlrichs, M. Bär, H.-P. Baron, R. Bauernschmitt, S. Böcker, P. Deglmann, M. Ehrig, K. Eichkorn, S. Elliott, F. Furche, F. Haase, M. Häser, H. Horn, C. Hättig, C. Huber, U. Huniar, M. Kattannek, A. Köhn, C. Kölmel, M. Kollwitz, K. May, C. Ochsenfeld, H. Öhm, A. Schäfer, U. Schneider, M. Sierka, O. Treutler, B. Unterreiner, M. von Arnim, F. Weigend, P. Weis, H. Weiss, TURBOMOLE 5.5, Universität Karlsruhe, FRG, 2002.

53. M. J. Frisch, G. W. Trucks, H. B. Schlegel, G. E. Scuseria, M. A. Robb, J. R. Cheeseman, V. G. Zakrzewski, J. A. Montgomery, J. R. E. Stratmann, J. C. Burant, S. Dapprich, J. M. Millam, A. D. Daniels, K. N. Kudin, M. C. Strain, O. Farkas, J. Tomasi, V. Barone, M. Cossi, R. Cammi, B. Mennucci, C. Pomelli, C. Adamo, S. Clifford, J. Ochterski, G. A. Petersson, P. Y. Ayala, Q. Cui, K. Morokuma, D. K. Malick, A. D. Rabuck, K. Raghavachari, J. B. Foresman, J. Cioslowski, J. V. Ortiz, A. G. Baboul, B. B. Stefanov, G. Liu, A. Liashenko, P. Piskorz, I. Komaromi, R. Gomperts, R. L. Martin, D. J. Fox, T. Keith, M. A. Al-Laham, C. Y. Peng, A. Nanayakkara, M. hallacombe, P. M. W. Gill, B. Johnson, W. Chen, M. W. Wong, J. L. Andres, C. Gonzalez, M. Head-Gordon, E. S. Replogle, J. A. Pople, Gaussian 98, Revision A.9; Gaussian, Inc.: Pittsburgh, Pa, 1998.

54. S. Tsuzuki, K. Honda, T. Uchimaru, M. Mikami, K. Tanabe, J. Am. Chem. Soc. 2002, 124, 104.

55. (a) S. F. Boys, Rev. Mod. Phys. 1960, 32, 296. (b) G. Schaftenaar, MOLDEN 3.8, CAOS/CAMM Center Nijmegen, NL, 2003.

56. J. Manna, K. D. John, M. D. Hopkins, Adv. Organometal. Chem. 1995, 38, 79. 
57. (a) G. Liehr, H.-J. Seibold, H. Behrens, J. Organomet. Chem. 1983, 248, 351. (b) P. G. Lenhert, C. M. Lukehart, K. Srinivasan, J. Am. Chem. Soc. 1984, 106, 124. (c) B. J. Brisdon, D. A. Edwards, J. W. White, M. G. B. Drew, J. Chem. Soc., Dalton Trans. 1980, 2129.

58. B. Morosin, J. Howatson, J. Organomet. Chem. 1970, $29,7$.

59. (a) X. Solans, J. Solans, C. Miravitlles, D. Miguel, V. Riera, J. M. Rubio-Gonzalez, Acta Crystallogr. C 1986, 42, 975. (b) G. A. Carriedo, D. Miguel, V. Riera, X. Solans, M. Font-Altaba, M. Coll, J. Organomet. Chem. 1986, 299, C43.

60. X.-M. Chen, Y.-X. Tong, Z.-T. Xu, T. C. W. Mark, J. Chem. Soc., Dalton Trans. 1995, 4001 and references cited therein.

61. G. B. Nikiforov, H. W. Roesky, T. Labahn, D. Vidovic, D. Neculai, Eur. J. Inorg. Chem. 2003, 433.

62. D. Walther, P. Gebhardt, R. Fischer, U. Kreher, H. Görls, Inorg. Chim. Acta 1998, 281, 181.

63. D. Reardon, G. Aharonian, S. Gambarotta, G. P. A. Yap, Organometallics 2002, 21, 786 and references cited therein.

64. C. Eaborn, P. B. Hitchcock, J. D. Smith, S. Zhang, W. Clegg, K. Izod, P. O’Shaughnessy, Organometallics 2000, 19, 1190 and references cited therein.

65. P. Friedrich, G. Besl, E. O. Fischer, G. Huttner, J. Organomet. Chem. 1977, 139, C68.

66. W. A. Herrmann, J. L. Hubbard, I. Bernal, J. D. Korp, B. L. Haymore, G. L. Hillhouse, Inorg. Chem. 1984, 23, 2978.

67. E. O. Fischer, W. Kleine, W. Schambeck, U. Schubert, Z. Naturforsch. 1981, 36b, 1575.

68. U. Schubert, Organometallics 1982, 1, 1085.

69. D. S. McGuinness, B. F. Yates, K. J. Cavell, Organometallics 2002, 21, 5408 and references cited therein.

70. B. L. Balzer, M. Cazanoue, M. Sabat, M. G. Finn, Organometallics 1992, 11, 1759.

71. H. Chen, R. A. Bartlett, H. V. R. Dias, M. M. Olmstead, P. P. Power, Inorg. Chem. 1991, 30, 2487 and references cited therein.

72. R. D. Adams, O.-S. Kwon, M. D. Smith, Inorg. Chem. 2002, 41, 5525.

73. (a) N. Kitajima, U. P. Singh, H. Amagai, M. Osawa, Y. Morooka, J. Am. Chem. Soc. 1991, 113, 7757. (b) P. A. Goodson, A. R. Oki, J. Glerup, D. J. Hodgson, J. Am. Chem. Soc. 1990, 112, 6248. (c) P. A. Goodson, D. J. Hodgson, Inorg. Chem. 1989, 28, 3606. 
74. (a) J. D. Scollard, D. H. McConville, N. C. Payne, J. J. Vittal, Macromolecules 1996, 29, 5241. (b) J. D. Scollard, D. H. McConville, J. Am. Chem. Soc. 1996, 118, 10008. (c) J. D. Scollard, D. H. McConville, J. J. Vittal, Organometallics 1997, 16, 4415.

75. (a) F. G. N. Cloke, B. R. Elvidge, P. B. Hitchcock, V. M. E. Lamarche, J. Chem. Soc., Dalton Trans. 2002, 2413. (b) P. W. Roesky, Organometallics 2002, 21, 4756.

76. H. Zhu, J. Chai, H. W. Roesky, M. Noltemeyer, H.-G. Schmidt, D. Vidovic, J. Magull, Eur. J. Inorg. Chem. 2003, 3113.

77. (a) D. C. Bradley, M. B. Hursthouse, K. M. A. Malik, R. Möseler, Transition Met. Chem. 1978, 3, 253. (b) B. D. Murray, P. P. Power, Inorg. Chem. 1984, 23, 4584.

78. H. Chen, R. A. Bartlett, H. V. R. Dias, M. M. Olmstead, P. P. Power, J. Am. Chem. Soc. 1989, $111,4338$.

79. M. M. Olmstead, P. P. Power, S. C. Shoner, Inorg. Chem. 1991, 30, 2547.

80. D. F. Shriver, M. A. Drezdzon, The Manipulation of Air-Sensitive Compounds, $2^{\text {nd }}$ Edn., Wiley-Interscience, New York, 1986.

81. G. M. Sheldrick, Acta Crystallogr. A 1997, 46, 467.

82. G. M. Sheldrick, SHELXS-97, Universität Göttingen, FRG, 1997.

83. N. Kuhn, T. Kratz, Synthesis 1993, 561.

84. J. Feldman, S. J. McLain, A. Parthasarathy, W. J. Marshall, J. C. Calabrese, S. D. Arthur, Organometallics 1997, 16, 1514.

85. R. J. Kern, J. Inorg. Nucl. Chem. 1962, 24, 1105.

86. B. Horvath, R. Möseler, E. G. Horvath, Z. Anorg. Allg. Chem. 1979, 450, 165.

87. B. Hübler-Blank, M. Witt, H. W. Roesky, J. Chem. Educ. 1993, 70, 408.

88. H. W. Roesky, Inorg. Chem. 2001, 40, 6855. 


\section{Lebenslauf}

Jianfang Chai, geboren am 30. Aug. 1976 in Anyang, Henan, China

Staatsangehörigkeit

Familienstand

\section{Schulausbildung}

Aug. 1983 - Jul. 1988

Aug. 1988 - Jul. 1991

Aug. 1991 - Jul. 1994

\section{Hochschulausbildung}

Sep. 1994 - Jul. 1998

Sep. 1998 - Jul. 2001

Sep. 2001 - Oct. 2001

Nov. 2001 - Oct. 2004

\author{
Chinesisch
}

verheiratet

Dongzhuangying Grundschule, Anyang, China

Liuguzhen No.1 Junior Middle School, Anyang, China

Huaxian No. 1 Senior Middle School, Anyang, China

Studium Chemie am Fachbereich Chemie der Xinyang

Normal College, Xinyang, China

Studium Chemie am Fachbereich Chemie der Nankai

University, Tianjin, China

Äquivalenzprüfung zum Diplomexamen - Fach

Chemie

Anfertigung der Dissertation unter Anleitung von Prof.

Dr. Dr. h. c. mult. H. W. Roesky am Institut für

Anorganische Chemie der Universität Göttingen 